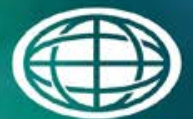

Savannah River

National Laboratory ${ }^{m}$

OPERATED BY SAVANNAH RIVER NUCLEAR SOLUTIONS

\title{
Visual Inspection of Defense Waste Processing Facility Melter 2 Interior after End of Service
}

K. M. Fox

B. C. Hodges

K. J. Imrich

D. C. Iverson

J. E. Owen

April 2018

SRNL-STI-2017-00428, Revision 0 
SRNL-STI-2017-00428

Revision 0

\section{DISCLAIMER}

This work was prepared under an agreement with and funded by the U.S. Government. Neither the U.S. Government or its employees, nor any of its contractors, subcontractors or their employees, makes any express or implied:

1. warranty or assumes any legal liability for the accuracy, completeness, or for the use or results of such use of any information, product, or process disclosed; or

2. representation that such use or results of such use would not infringe privately owned rights; or

3. endorsement or recommendation of any specifically identified commercial product, process, or service.

Any views and opinions of authors expressed in this work do not necessarily state or reflect those of the United States Government, or its contractors, or subcontractors.

\section{Printed in the United States of America \\ Prepared for U.S. Department of Energy}


Keywords: DWPF, Melter 2, Inspection, Refractory, Glass

Retention: Permanent

\title{
Visual Inspection of Defense Waste Processing Facility Melter 2 Interior after End of Service
}

\author{
K. M. Fox \\ B. C. Hodges \\ K. J. Imrich \\ D. C. Iverson \\ J. E. Owen
}

April 2018 


\section{REVIEWS AND APPROVALS}

AUTHORS:

K. M. Fox, Waste Form Processing Technology $\quad$ Date

B. C. Hodges, Melter and Saltstone Engineering Date

K. J. Imrich, Corrosion and Materials Performance Date

D. C. Iverson, Melter and Saltstone Engineering Date

J. E. Owen, Melter and Saltstone Engineering $\quad$ Date

TECHNICAL REVIEW:

D. L. McClane, Waste Form Processing Technologies, Reviewed per E7 $2.60 \quad$ Date

APPROVAL:

F. M. Pennebaker, Chemical Processing Technologies

Date

D. E. Dooley, Director, Chemical Processing Technologies

Date

E. J. Freed, Chief Engineer, DWPF Engineering

Date 


\section{ACKNOWLEDGEMENTS}

The authors thank Montenius Collins, Jeff Coughlin, Michael Dalmaso, and Dale Marzolf of SRNL R\&D Engineering for the development, construction, and operation of the camera systems used in the inspection of Melter 2. 


\section{EXECUTIVE SUMMARY}

Defense Waste Processing Facility (DWPF) Melter 2 reached its end of service life after nearly 14 years. A visual inspection of the interior of the melter was performed using a remotely operated camera to provide insight into melter performance and potential failure mechanisms. The condition of the interior of the melter was generally good considering its relatively long service life. The plenum refractory appeared to be in good condition. Spalling and wear of the glass contact refractory was evident at the melt line. There appeared to be some degree of degradation and deposition of material at the dome heater penetrations. Deformation, or sagging of the dome heaters was visible. Only the top surfaces of the upper electrodes were visible due to the full inventory of glass remaining after melter shutdown. The electrodes exhibited small cracks as well as minor deformation (creep or slumping). The lower electrode failure mechanism could not be determined since it was not visible.

An unexpected mound of material was visible near the center of the solidified melt pool. Samples of the mound material were retrieved for visual inspection, and observations concluded the samples to be black, shiny, porous glass. Based on the visual observations of the material collected from the mound, there was no reason to suspect issues with the quality of the glass product in Melter 2. 


\section{TABLE OF CONTENTS}

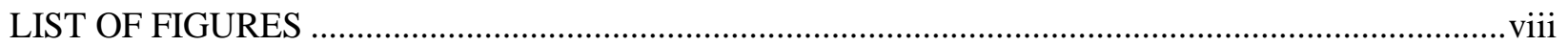

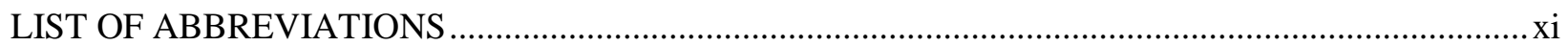

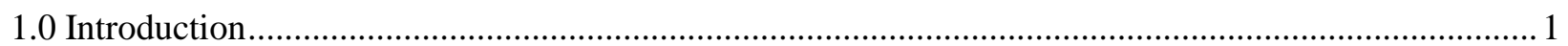

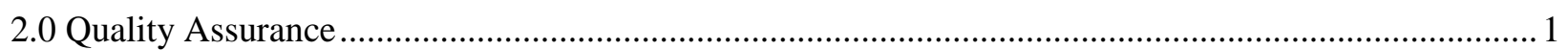

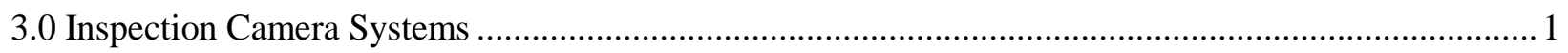

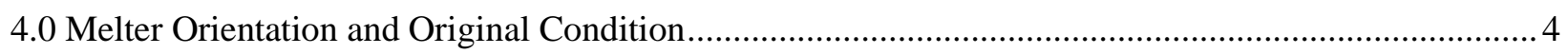

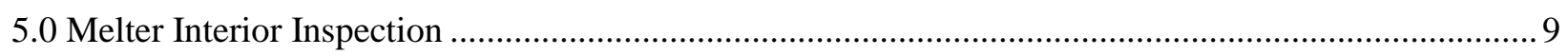

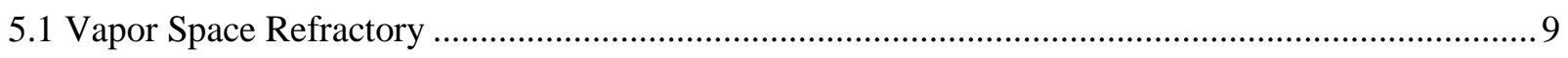

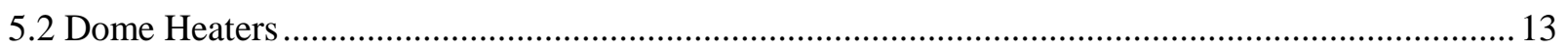

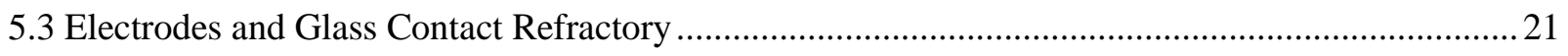

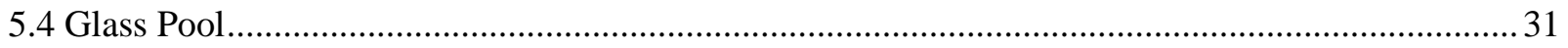

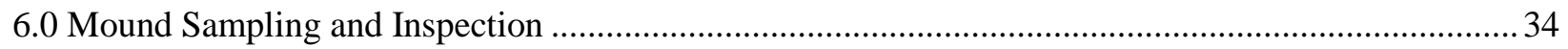

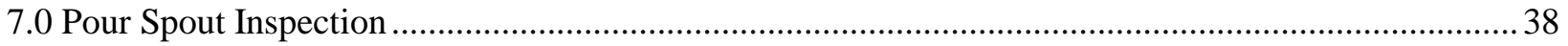

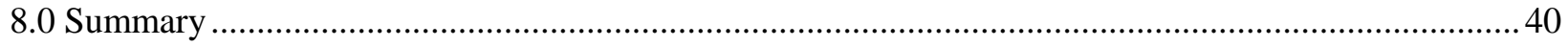

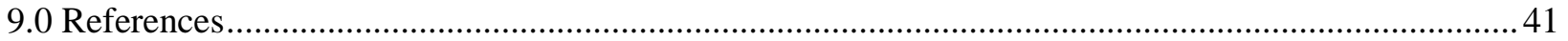




\section{LIST OF FIGURES}

Figure 3-1. Diagram of Melter Vapor Space Inspection Camera (adapted from R-R1-S-00165) ............... 3

Figure 3-2. Diagram of Pour Spout Inspection Camera (adapted from R-R1-S-00167) .......................... 4

Figure 4-1. Diagram of melter top head with major nozzles labeled..................................................... 5

Figure 4-2. Side view of DWPF melter showing orientation with Plant North ....................................... 6

Figure 4-3. Cross section of DWPF melter showing location of dome heaters ....................................... 7

Figure 4-4. Stitched panoramic photos of DWPF Melter 3 prior to installation......................................... 8

Figure 4-5. Stitched panoramic photos of DWPF Melter 3 with components labeled .............................. 9

Figure 5-1. Overview of Melter 2 vapor space refractory and components .......................................... 10

Figure 5-2. Melter 2 vapor space refractory and dome heaters............................................................ 10

Figure 5-3. Deposition of material on vapor space refractory and exposed area near Bubbler C2 ........... 11

Figure 5-4. Exposed face of Korundal XD vapor space refractory near Bubbler C2 .............................. 11

Figure 5-5. Underside of Melter 2 top head showing vapor space refractory and nozzle penetrations ..... 12

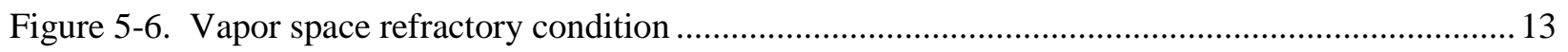

Figure 5-7. Dome heater penetrations, northwest side of melter ....................................................... 13

Figure 5-8. Dome heater penetration detail ..................................................................................... 14

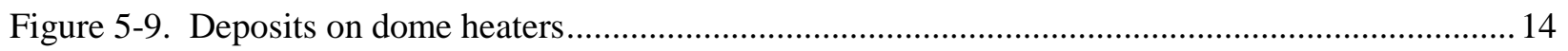

Figure 5-10. Dome heater penetrations, northeast side of melter ........................................................... 15

Figure 5-11. Dome heater penetrations, upper pair (A), northeast side of melter ................................... 16

Figure 5-12. Dome heater penetrations, upper pair (A), northeast side of melter, alternate view ............. 16

Figure 5-13. Dome heater penetrations, lower pair, northeast side of melter ......................................... 17

Figure 5-14. Dome heater penetrations, upper pair, southeast side of melter........................................ 17

Figure 5-15. Detail of dome heater penetrations, lower pair, southeast side of melter............................ 18

Figure 5-16. Dome heater penetrations, southeast side of melter, view from above ................................ 18

Figure 5-17. Dome heater penetrations, southwest side of melter ........................................................ 19

Figure 5-18. Deformation of dome heaters, east side of melter.............................................................20

Figure 5-19. Deformation of dome heaters, west side of melter .......................................................... 20

Figure 5-20. View along dome heaters showing deformation, west side of melter ................................. 21 
Figure 5-21. View along dome heaters showing deformation, lower pair, west side of melter................ 21

Figure 5-22. Upper electrode, southeast side of melter ........................................................................ 22

Figure 5-23. Refractory pieces visible behind upper electrode.................................................................. 23

Figure 5-24. Original electrode and glass contact refractory configuration ........................................... 24

Figure 5-25. Top down view of original electrode and glass contact refractory configuration................. 25

Figure 5-26. Upper electrode, southeast side of melter, viewed from above.......................................... 26

Figure 5-27. Detail view of cracks visible on top of upper electrode, southeast side of melter ................ 27

Figure 5-28. Larger crack visible on top of upper electrode, southeast side of melter ........................... 27

Figure 5-29. Upper electrode (L3), northwest side of melter …............................................................. 28

Figure 5-30. Detail view of upper electrode (L3), northwest side of melter........................................... 28

Figure 5-31. Approximation of observed upper electrode slumping ......................................................29

Figure 5-32. Second detail view of upper electrode (L3), northwest side of melter................................ 29

Figure 5-33. Glass contact refractory at melt line, west side of melter.................................................. 30

Figure 5-34. Second view of glass contact refractory at melt line, west side of melter............................ 30

Figure 5-35. Southeast edge of mound of material visible on glass pool .................................................31

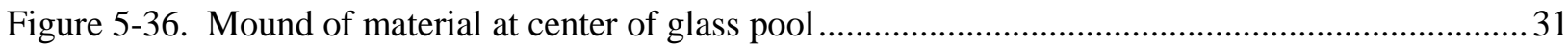

Figure 5-37. Fissures visible in mound of material............................................................................. 32

Figure 5-38. View of mound of material after contacting with glass pump through center nozzle............ 33

Figure 5-39. Alternate view of mound of material after contacting with glass pump ............................33

Figure 5-40. Cracked material atop mound after contacting with glass pump through center nozzle........34

Figure 5-41. Closer view of cracked material atop mound ......................................................................34

Figure 6-1. Foamy glass retrieved from mound in Melter 2 ................................................................ 35

Figure 6-2. Alternate view of foamy glass retrieved from mound in Melter 2 ...................................... 35

Figure 6-3. First sampler with glass collected from mound............................................................... 36

Figure 6-4. Alternate view of first sampler with glass collected from mound........................................36

Figure 6-5. Example of foamy glass generated via rapid gas evolution ................................................ 37

Figure 6-6. Second sampler with glass collected from mound ….......................................................... 38

Figure 6-7. Alternate view of second sampler with glass collected from mound ..................................... 38

Figure 7-1. View of pour spout looking up toward top of melt cell ..................................................... 39 
SRNL-STI-2017-00428

Revision 0

Figure 7-2. Closer view of pour spout showing region of removable insert.......................................... 39 


\section{LIST OF ABBREVIATIONS}

$\begin{array}{ll}\text { CCD } & \text { Charge Coupled Device } \\ \text { DWPF } & \text { Defense Waste Processing Facility } \\ \text { HLW } & \text { High-level Waste } \\ \text { LED } & \text { Light Emitting Diode } \\ \text { SRNL } & \text { Savannah River National Laboratory } \\ \text { SRS } & \text { Savannah River Site }\end{array}$




\subsection{Introduction}

Defense Waste Processing Facility (DWPF) Melter 2 feeding and pouring operations were terminated on January 26, 2017, due to a failure of the melter pour spout heater. During troubleshooting activities for the heater, the melter experienced a failure of the melter lower electrodes (L2/L4) on February 1, 2017. Investigation of the lower electrode event determined that it was a result of a significant failure of the melter L4 electrode at the electrode stem. These issues led to the decision to replace Melter 2 with Melter 3 after 14 years of service. Melter 2 produced 2,819 canisters, or approximately 10,868,000 pounds, of vitrified high level radioactive waste (HLW). The melter significantly exceeded its design life of two years. ${ }^{1}$ The melter has operated since February 2013 with a failed Dome Heater D. Melter 2 was successfully retrofit with melt pool agitation bubblers in September 2010 to increase the rate of glass production. The melter was operated at a temperature of 1050 to $1200{ }^{\circ} \mathrm{C}$ and produced glass at a rate of 90 to 225 pounds of glass per hour. A visual inspection of Melter 2 was completed after shutdown and cooling to identify the condition of materials of construction, including the vapor space and glass contact refractory, dome heaters, and upper melt pool electrodes. The circumstances leading to the end of service for Melter 2 necessitated a shutdown with a full inventory of glass in the melter. This limited the inspection to components visible at or above the melt line.

A similar inspection was completed for DWPF Melter 1 after it reached the end of its service life. ${ }^{2}$ The Melter 1 inspection found that the vapor space and glass contact refractory blocks were in excellent condition, with little evidence of spalling or corrosion. The Inconel ${ }^{\mathrm{TM}} 690$ top head components and dome heaters were also in good condition. The upper electrodes in Melter 1 experienced significant deflection, which was attributed to extended operation at temperatures in excess of $1150{ }^{\circ} \mathrm{C} .^{2}$

Section 3.0 of this report describes the camera systems that were designed and constructed to enable the inspection of the contaminated melter in a remotely operated environment. Section 4.0 presents examples of the original condition of the melter and describes orientation of the major components. Section 5.0 provides still photos and interpretation resulting from the visual inspection of the interior of Melter 2. Section 6.0 describes the collection and visual inspection of a sample of material from a mound observed at roughly the center of the solidified melt pool. Section 7.0 describes the limited visual inspection of the pour spout. The results of the melter inspection are summarized in Section 8.0.

\subsection{Quality Assurance}

Requirements for performing reviews of technical reports and the extent of review are established in manual E7 2.60. SRNL documents the extent and type of review using the SRNL Technical Report Design Checklist contained in WSRC-IM-2002-00011, Rev. 2.

\subsection{Inspection Camera Systems}

Two camera systems were developed and utilized for the inspection of Melter 2. The first system was designed for inspection of the melter vapor space via insertion through the off-gas nozzles. This required that the diameter of the camera system be less than 8 inches, and operate while suspended from the in-cell crane above the melter. A pan-tilt-zoom digital camera, model PTZ-WIR12X, ${ }^{a}$ was adapted for this purpose. The camera contained a 1/3 inch charge coupled device (CCD) with a resolution of $967 \times 494$ pixels, and utilized a 10x optical zoom lens. Integrated with the camera were six infrared LEDs to provide illumination within the melter. The camera mount allowed for 360 degrees of rotation and 90 degrees of tilt (horizontal to straight down). A transparent dome enclosure protected the camera from damage since contact with components inside the melter was expected. The enclosed camera was suspended at the end of a chain with a lifting bail on the opposite end (Figure 3-1), such that it could be lowered into the melter

\footnotetext{
${ }^{\text {a }}$ CCTV Camera Pros, Lantana, Florida
} 
via the in-cell crane. ${ }^{a}$ Use of a chain, rather than a rigid pole or pipe, allowed the camera to work its way around the melter's dome heaters as it was lowered into the vapor space. Video from the camera was captured and stored on a digital recorder.

The second system was designed for inspection of the interior of the melter pour spout and the glass breakover point at the top of the riser. Inspection of this portion of the melter required that a camera be inserted up through the pour spout, which has an inside diameter of approximately two inches. A specialized apparatus was built for this purpose. ${ }^{\mathrm{b}}$ The apparatus essentially consistent of a one inch diameter stainless steel tube, mounted on a rotating base that could be operated by the telerobotic manipulator in the melter cell. A RIDGID ${ }^{\circledR}$ digital inspection camera ${ }^{\mathrm{C}}$ was integrated into the spout viewing tool. A mirror at the top of the tool allowed for viewing perpendicular to the long axis of the pipe as it was inserted into the pour spout, and rotating the pipe rotated the viewing angle (Figure 3-2). Video from this camera was again captured and stored on a digital recorder.

a See SRNL drawings R-R2-S-00053 and R-R1-S-00165 for reference

b See SRNL drawing R-R1-S-00167 for reference

c Ridge Tool Company, Elyria, Ohio 


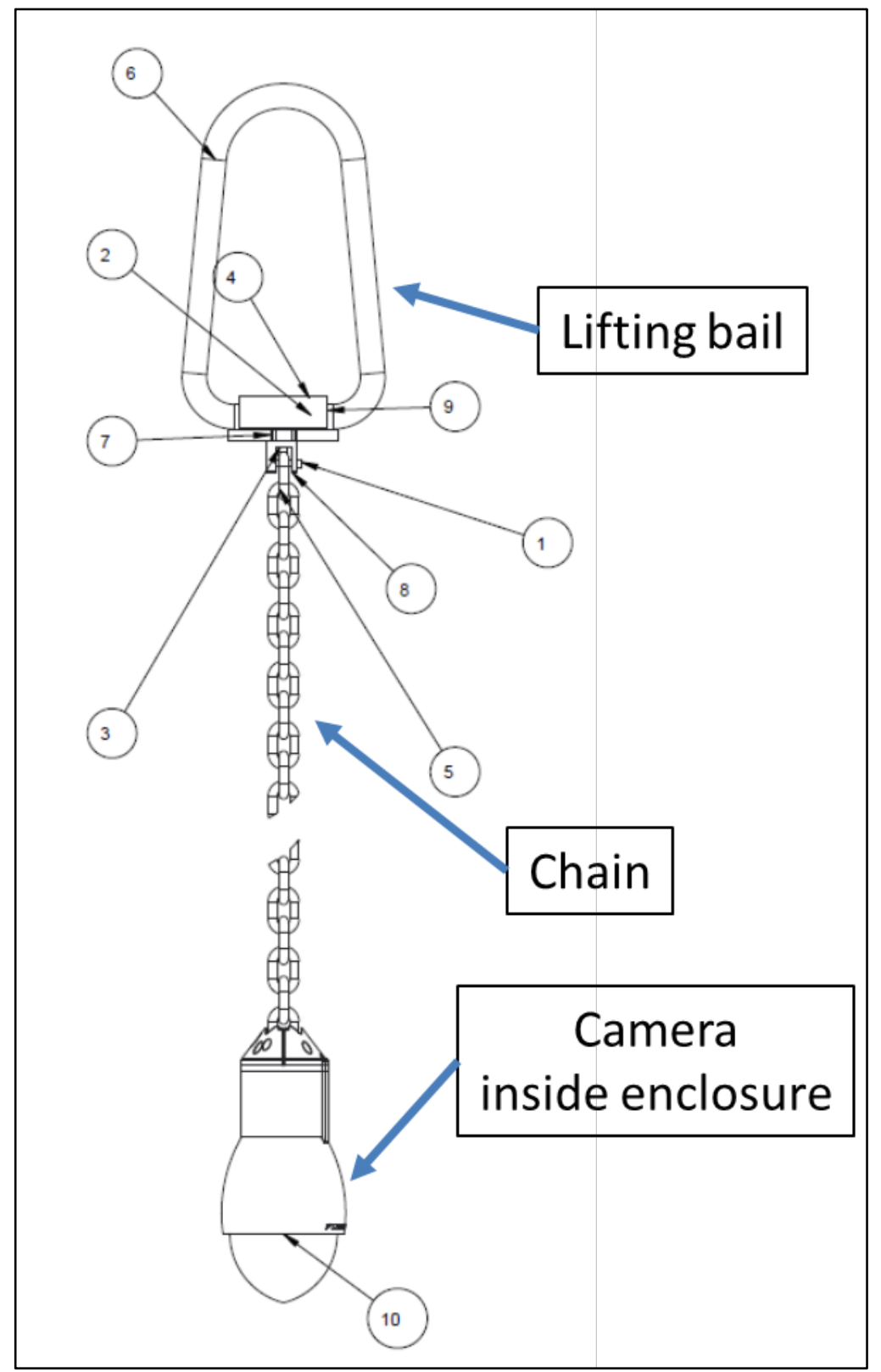

Figure 3-1. Diagram of Melter Vapor Space Inspection Camera (adapted from R-R1-S-00165) 


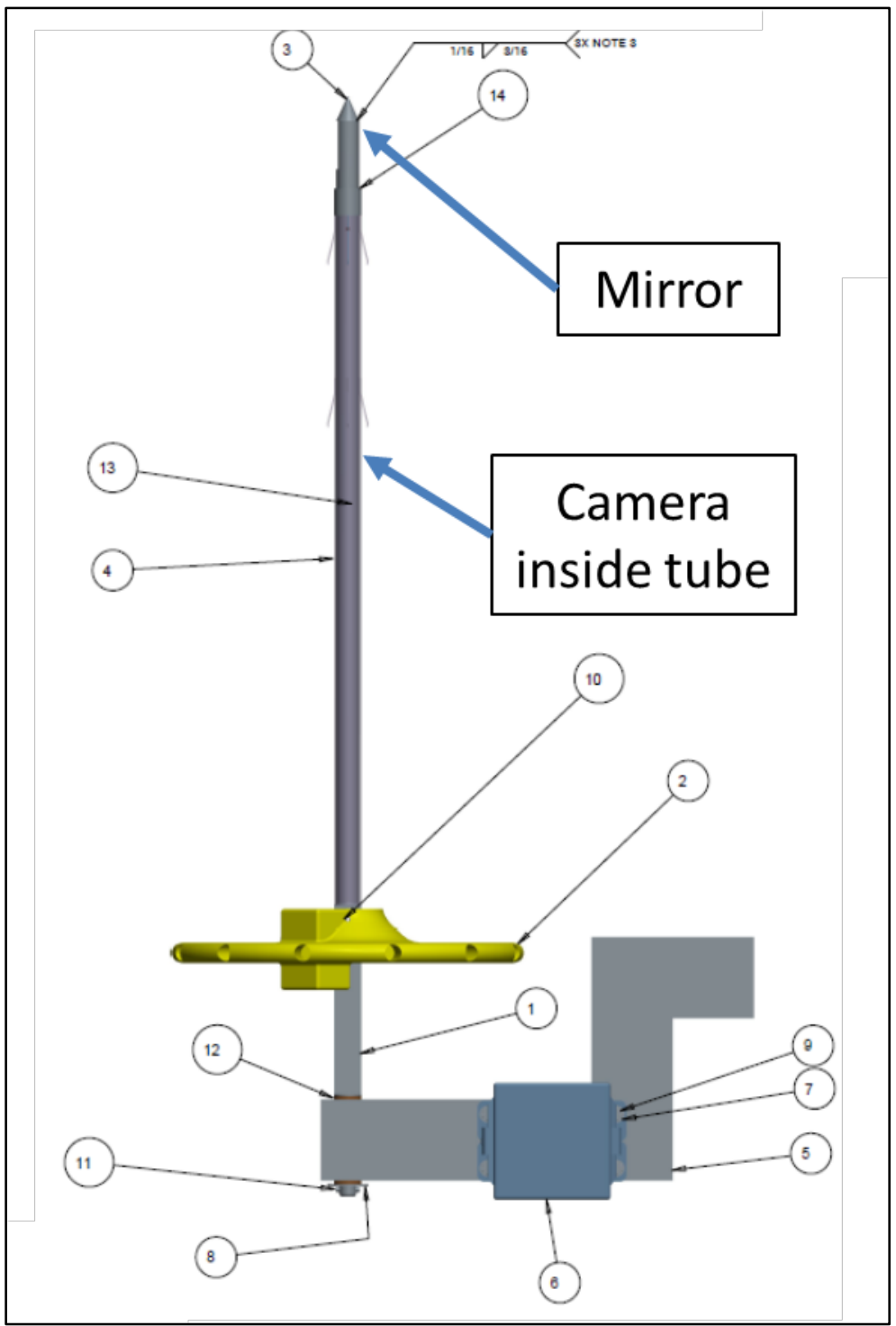

Figure 3-2. Diagram of Pour Spout Inspection Camera (adapted from R-R1-S-00167)

\subsection{Melter Orientation and Original Condition}

The majority of the DWPF Melter 2 visual inspection was completed via a camera inserted through the primary off-gas nozzle (Nozzle A). Figure 4-1 is provided to assist the reader with interpreting the orientation of images from the inspection. This drawing shows a top-down view of the melter top head with the major nozzles labeled. Nozzle A is located at approximately the 10 o'clock position in this drawing. The direction of Plant North is identified. Figure 4-2 is a side view of the melter, with Plant North again indicated. Note that Nozzle A is hidden behind Nozzle T (the backup off-gas nozzle) in this drawing. 


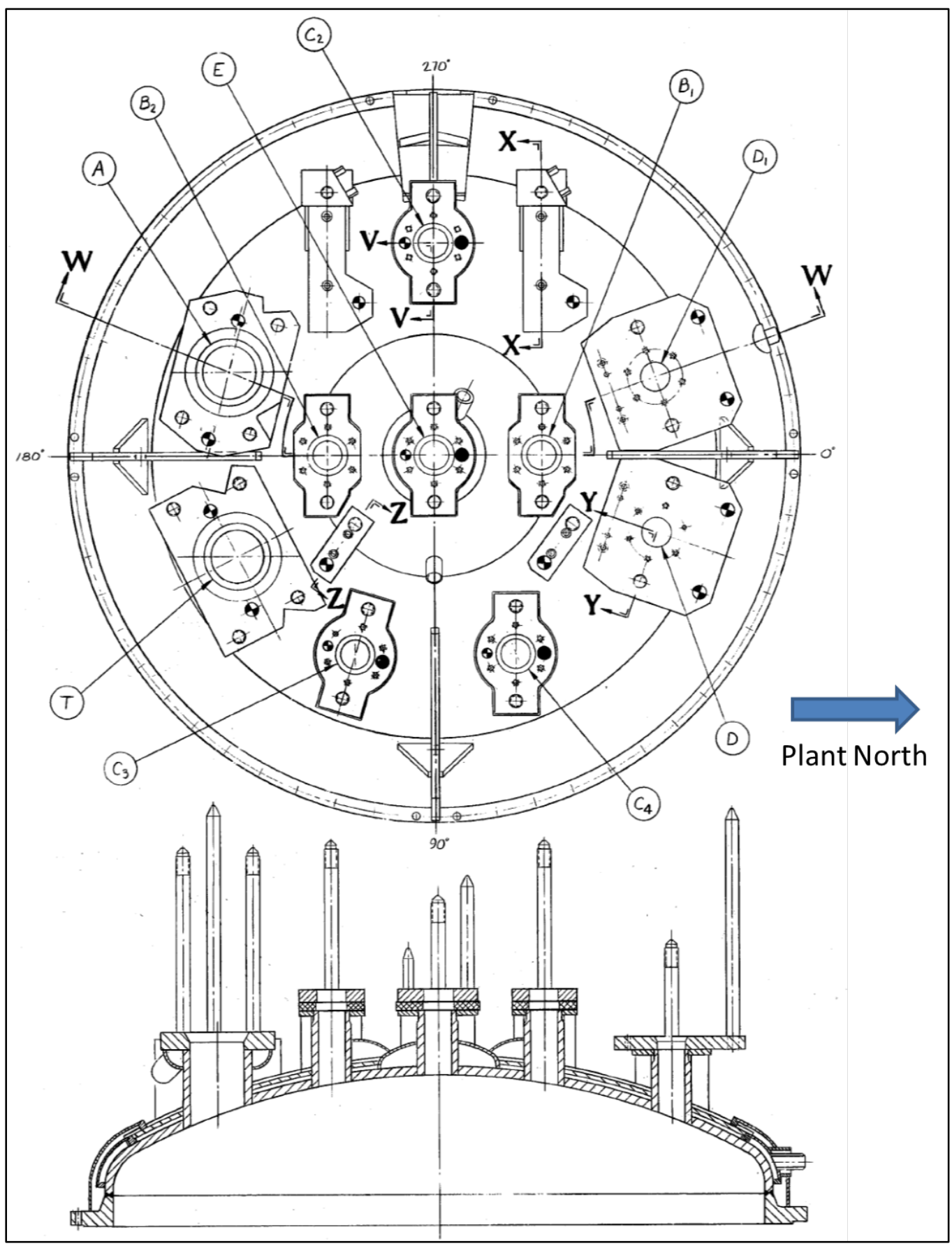

Figure 4-1. Diagram of melter top head with major nozzles labeled (adapted from drawing W801354) 


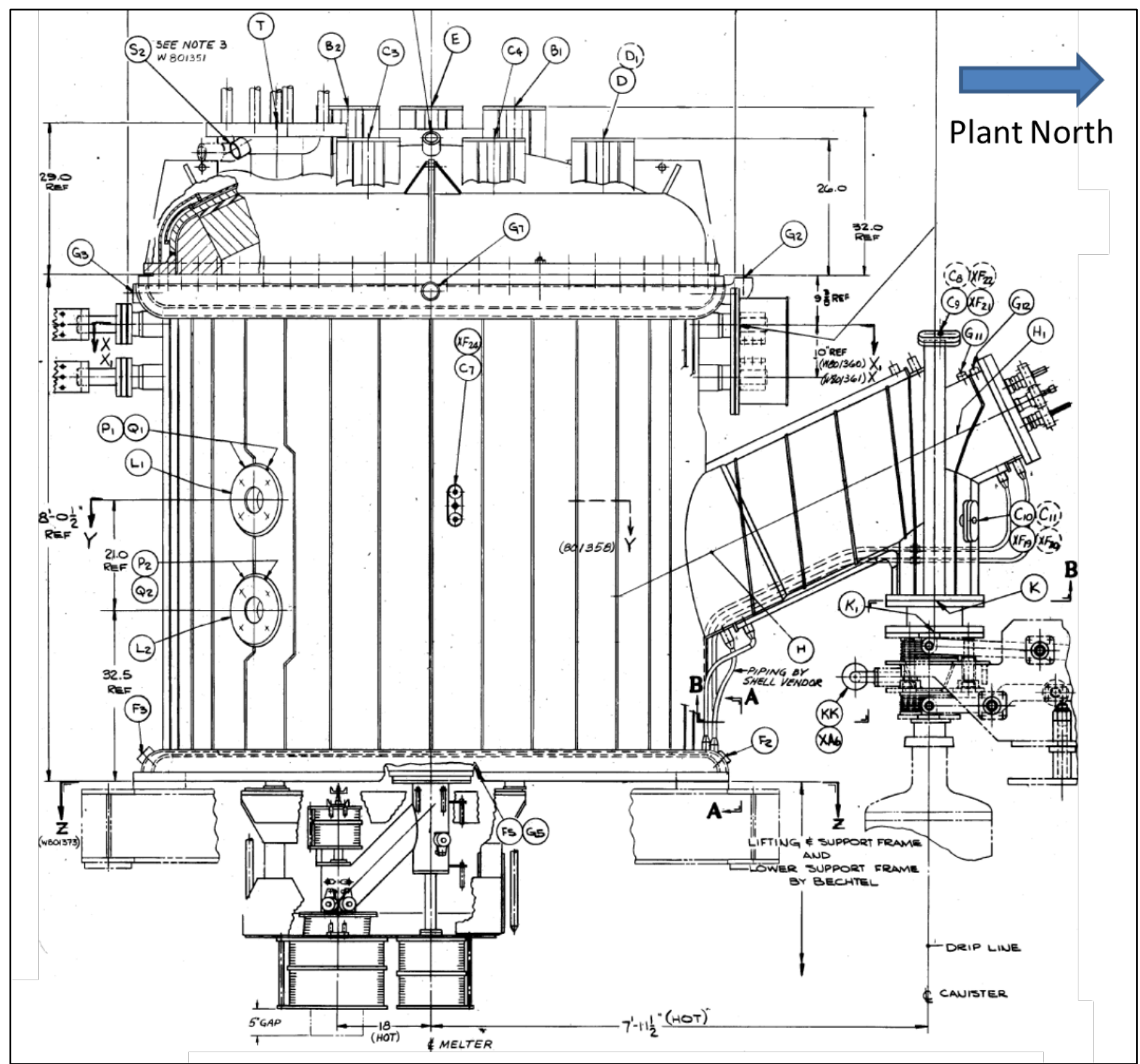

Figure 4-2. Side view of DWPF melter showing orientation with Plant North (adapted from drawing W801352)

A prominent feature in the inspection of the melter vapor space is the dome heaters. Figure 4-3 is a topdown cutaway view of the melter showing the orientation of the dome heaters. Note that there are four pairs of dome heaters in total, with the two top pairs visible in this drawing. The locations of other top head components present in the melter are identified by the hatched circles in this diagram, corresponding to Nozzles C2, B1, C4, C3, and B2 in Figure 4-1. 


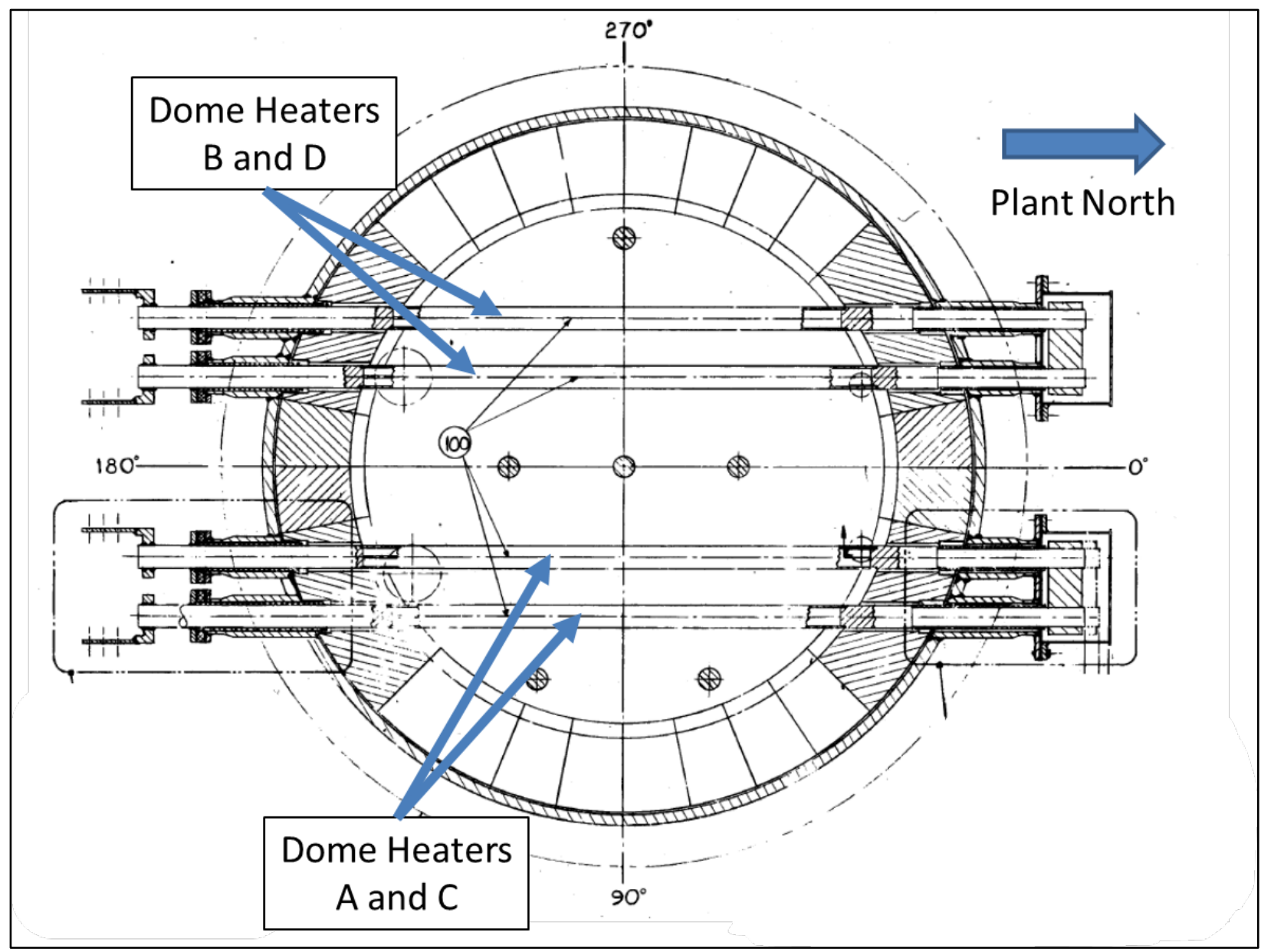

Figure 4-3. Cross section of DWPF melter showing location of dome heaters (adapted from drawing W801360)

The interior of DWPF Melter 3 was photographed prior to installation, providing an opportunity to compare images from the Melter 2 inspection to its as-built condition as no significant changes have been made to the design and construction of DWPF melters. A series of wide-angle photographs of the interior of Melter 3 were taken through the primary off-gas nozzle (Nozzle A) and stitched together to form panoramic views at a series of heights. The resulting view of the interior of Melter 3 is shown in Figure 4-4. Figure 4-5 is the same series of photographs with labels added for the visible components. These photos serve as a helpful reference for the following description of the Melter 2 inspection. Note that the upper two panoramas in Figure 4-4 and Figure 4-5 represent what was visible during the inspection. 
SRNL-STI-2017-00428

Revision 0

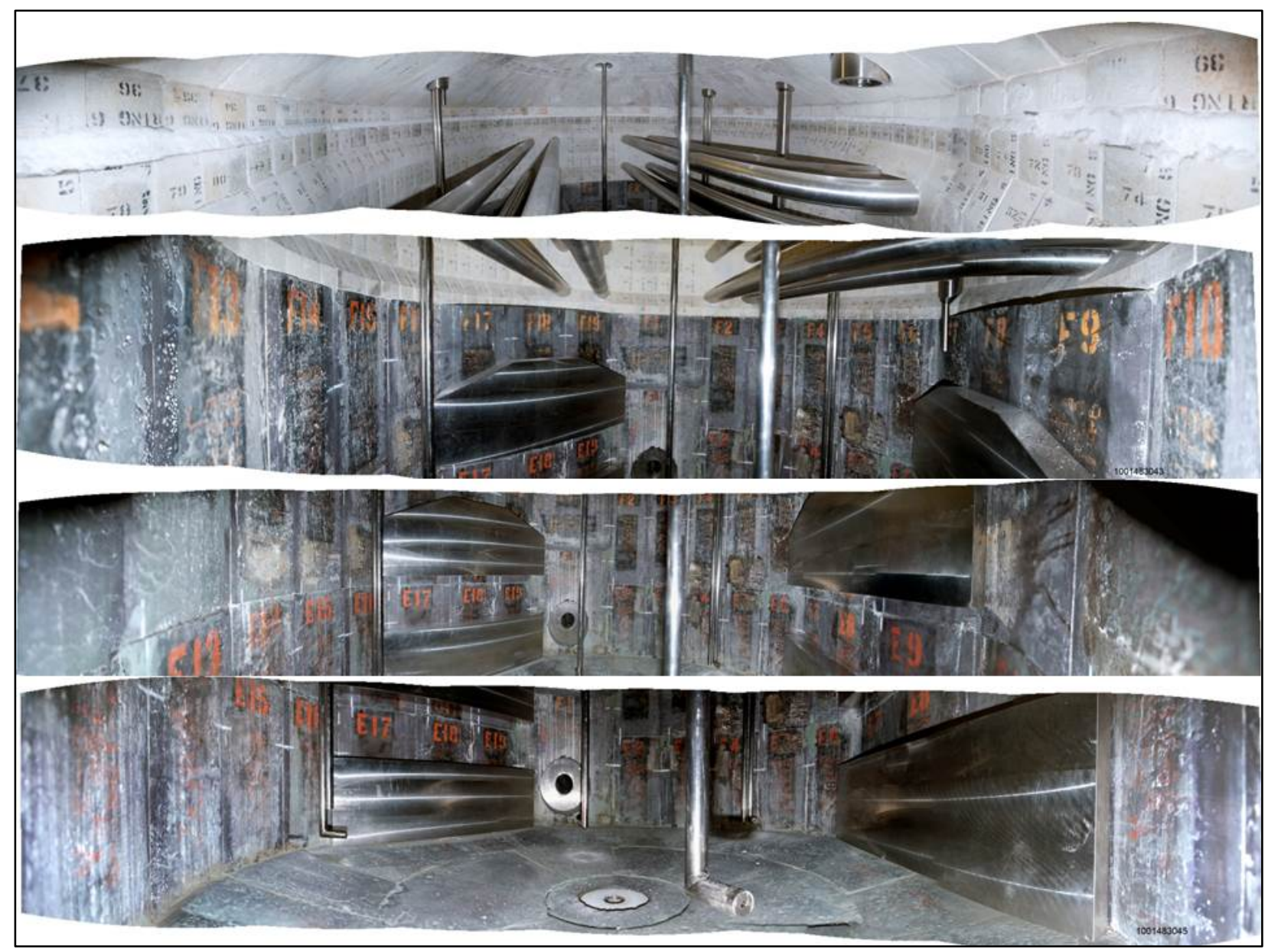

Figure 4-4. Stitched panoramic photos of DWPF Melter 3 prior to installation 


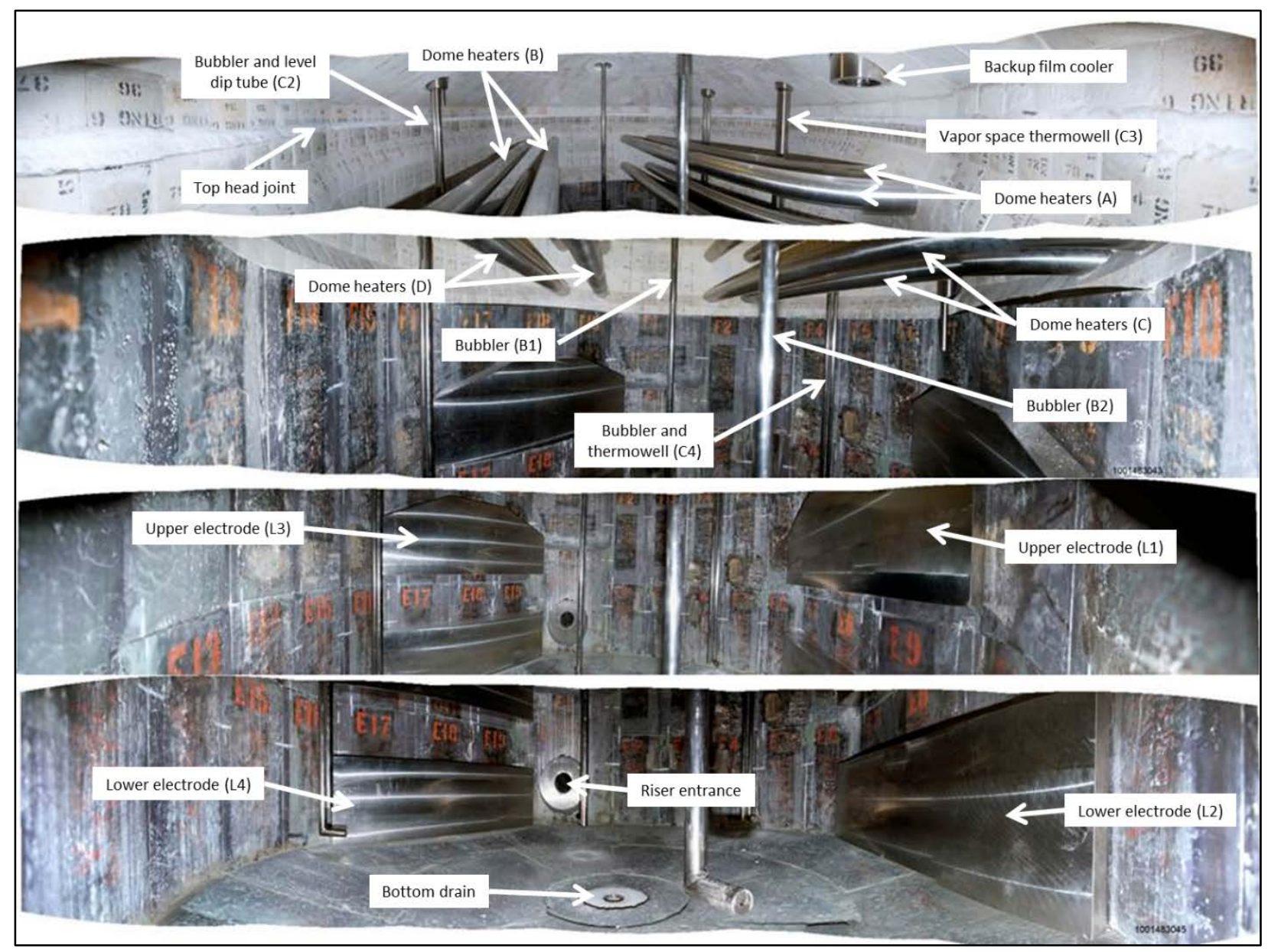

Figure 4-5. Stitched panoramic photos of DWPF Melter 3 with components labeled

\subsection{Melter Interior Inspection}

\subsection{Vapor Space Refractory}

The visual inspection of the interior of DWPF Melter 2 started by inserting the camera system through the primary off-gas nozzle (Nozzle A). Overviews of the vapor space refractory and components are shown in Figure 5-1 and Figure 5-2. The melter feed tube was removed for reuse prior to cooling of the glass pool. The bubbler tubes and vapor space thermowell remained. The vapor space refractory appeared to be in good condition after nearly 14 years of melter operation. Deposition of material on the refractory surfaces was visible and significant, which precluded direct observation of most of the refractory. Some of this accumulated material appeared to have spalled off during cooling. Figure 5-3 shows an area of the Korundal XD refractory that appears to have been exposed after deposits spalled away from its surface. A closer view of this area, near to the C2 bubbler and level dip tube, is shown in Figure 5-4. 


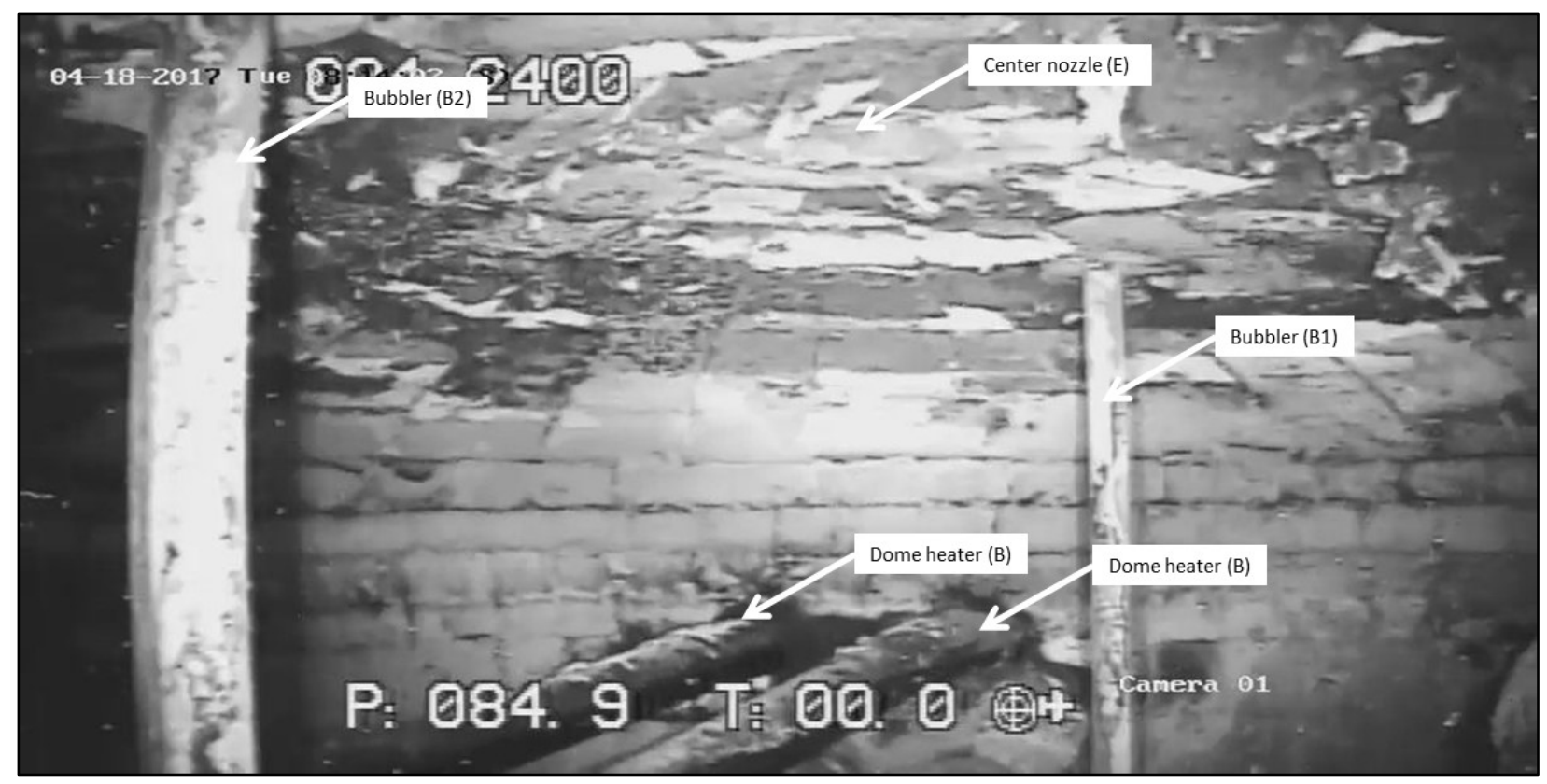

Figure 5-1. Overview of Melter 2 vapor space refractory and components

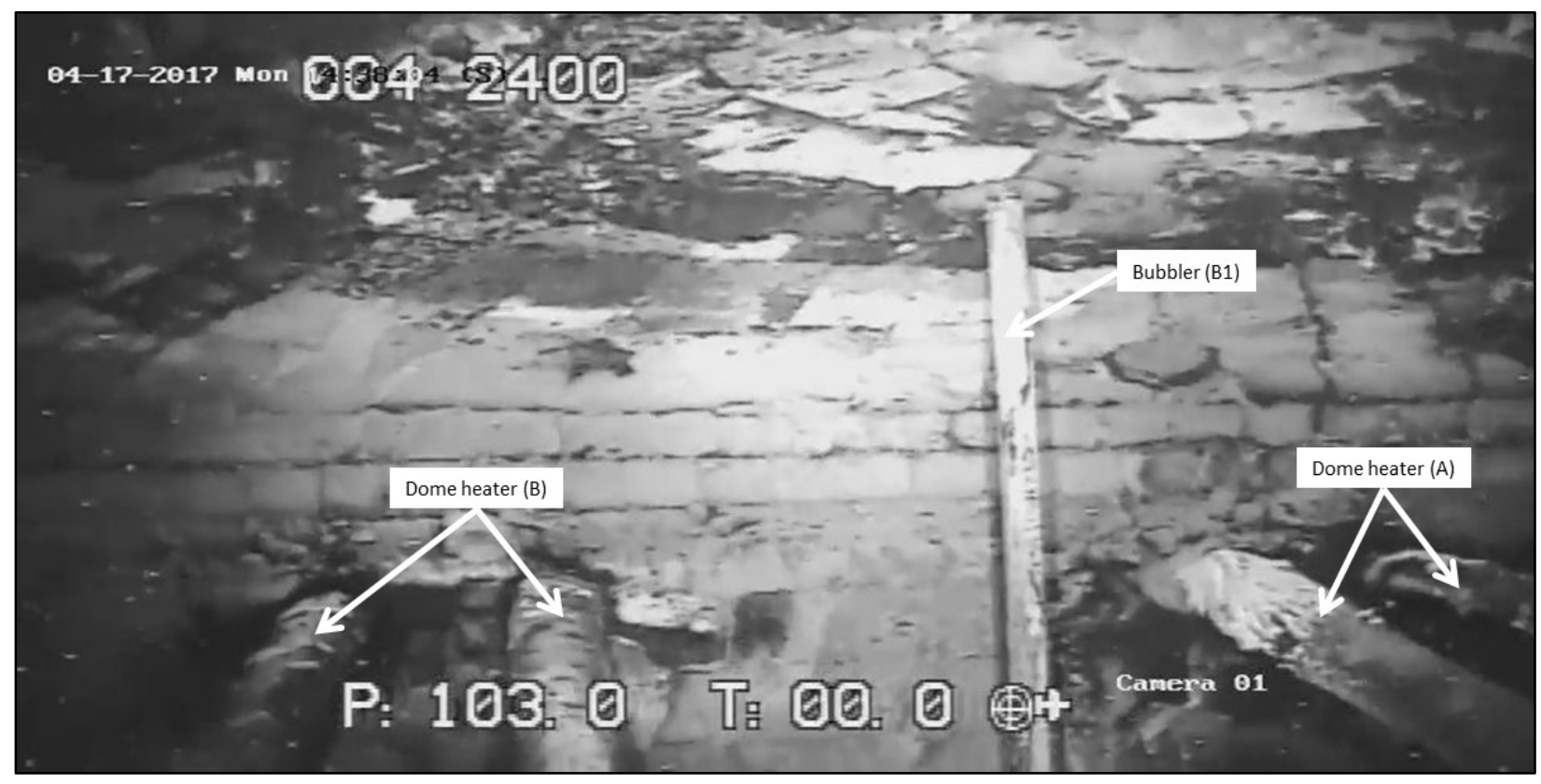

Figure 5-2. Melter 2 vapor space refractory and dome heaters 


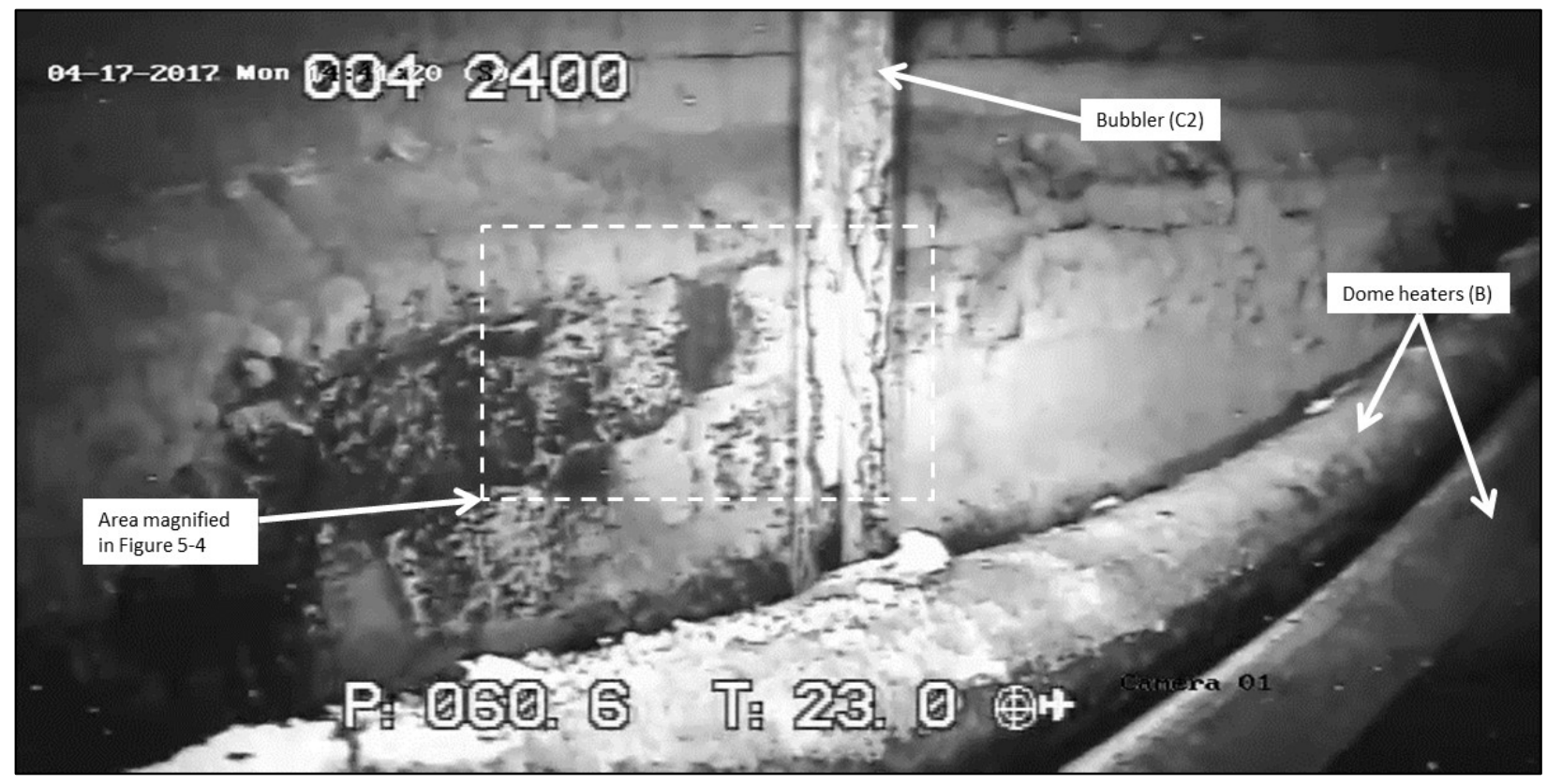

Figure 5-3. Deposition of material on vapor space refractory and exposed area near Bubbler C2 (west side of melter)

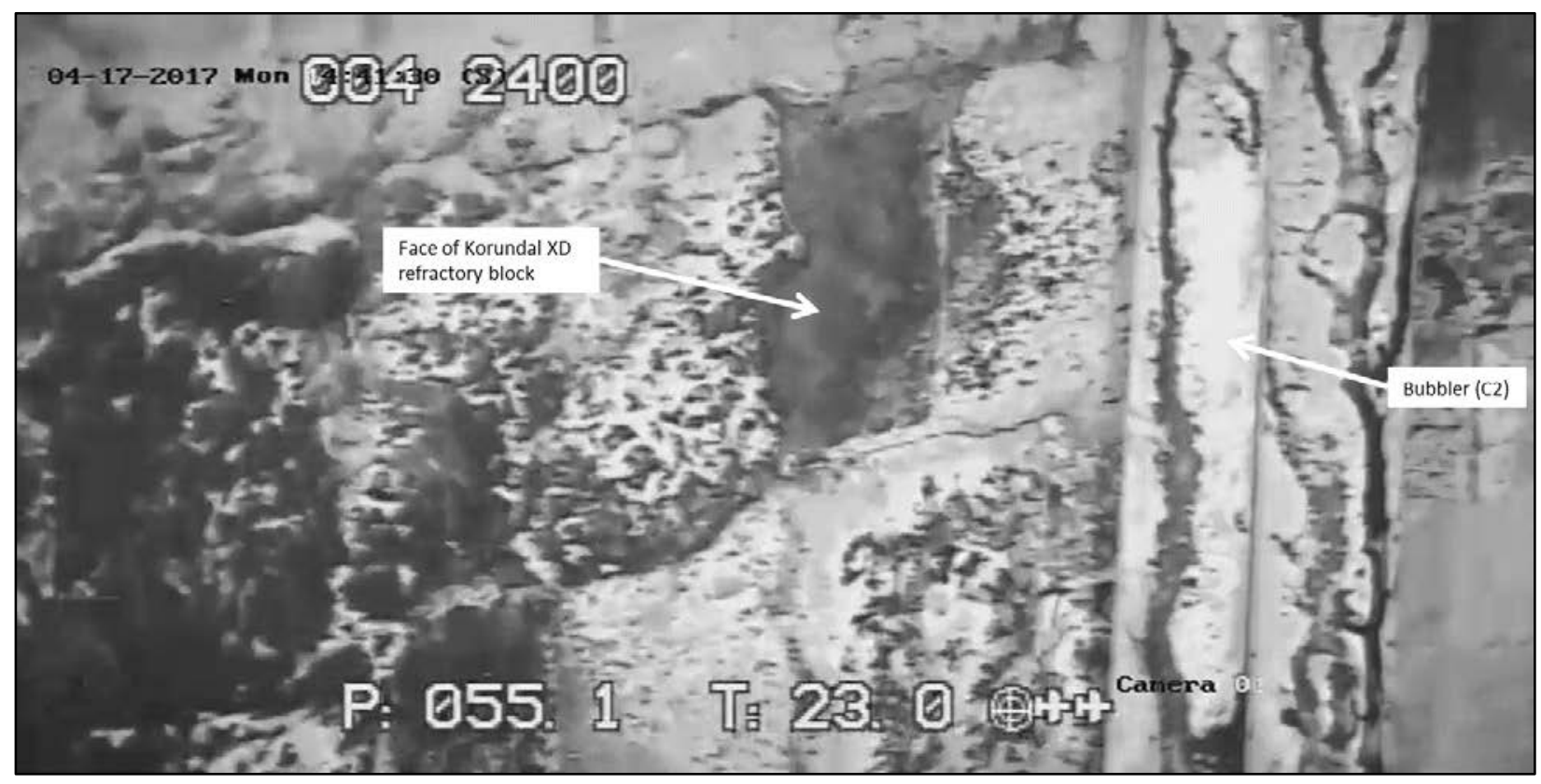

Figure 5-4. Exposed face of Korundal XD vapor space refractory near Bubbler C2

Figure 5-5 provides a view of the melter top head from below, captured by lowering the camera onto the solidified glass pool. Figure 5-6 provides a closer view of the vapor space refractory. The hole visible at the top, left of center in this image is a borescope nozzle (Nozzle D). In general, the vapor space refractory exhibited a level of wear expected after of 14 years of continuous operation. No missing pieces of refractory were observed. Joints between refractory blocks appeared to remain tight. 


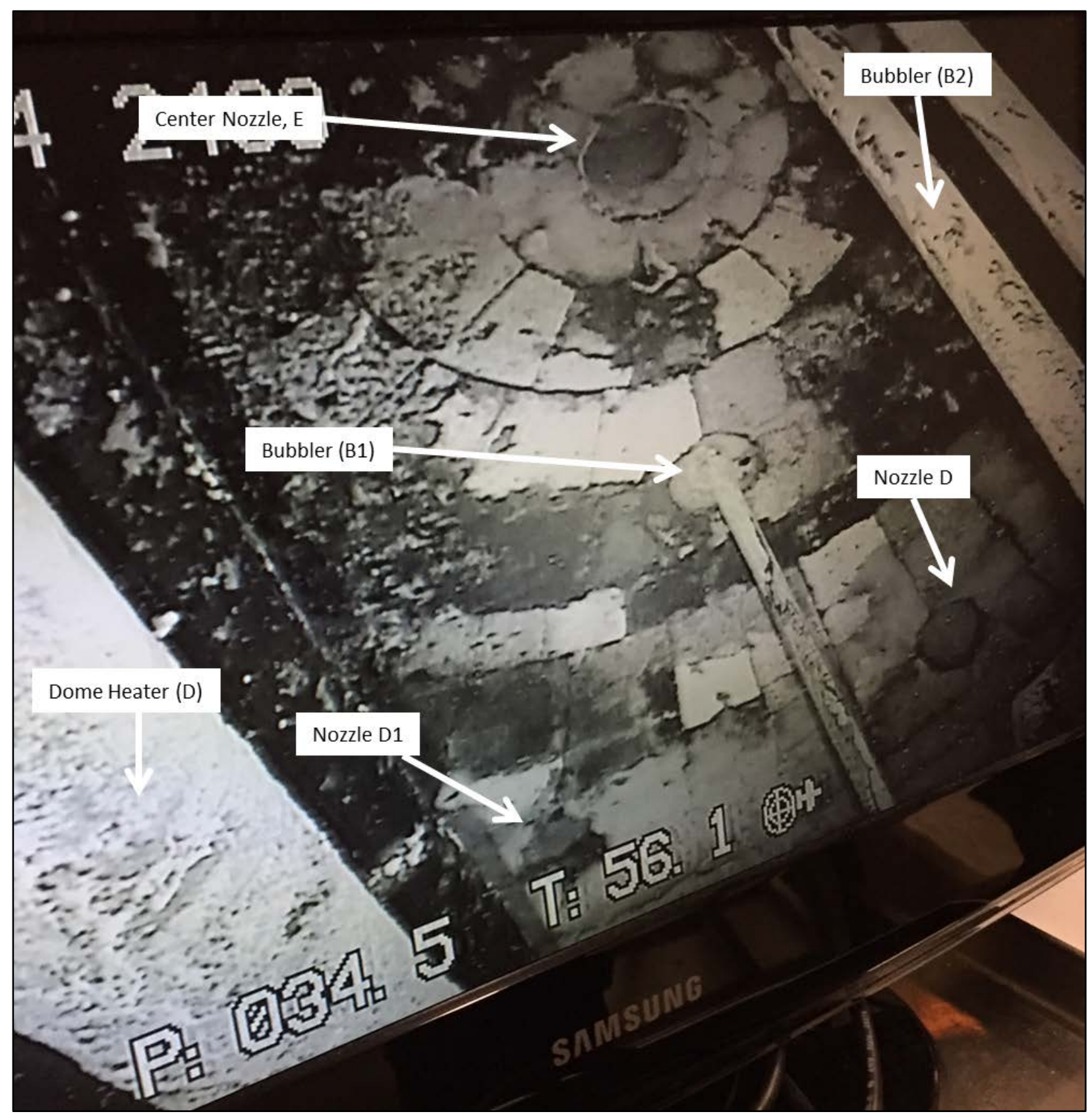

Figure 5-5. Underside of Melter 2 top head showing vapor space refractory and nozzle penetrations 


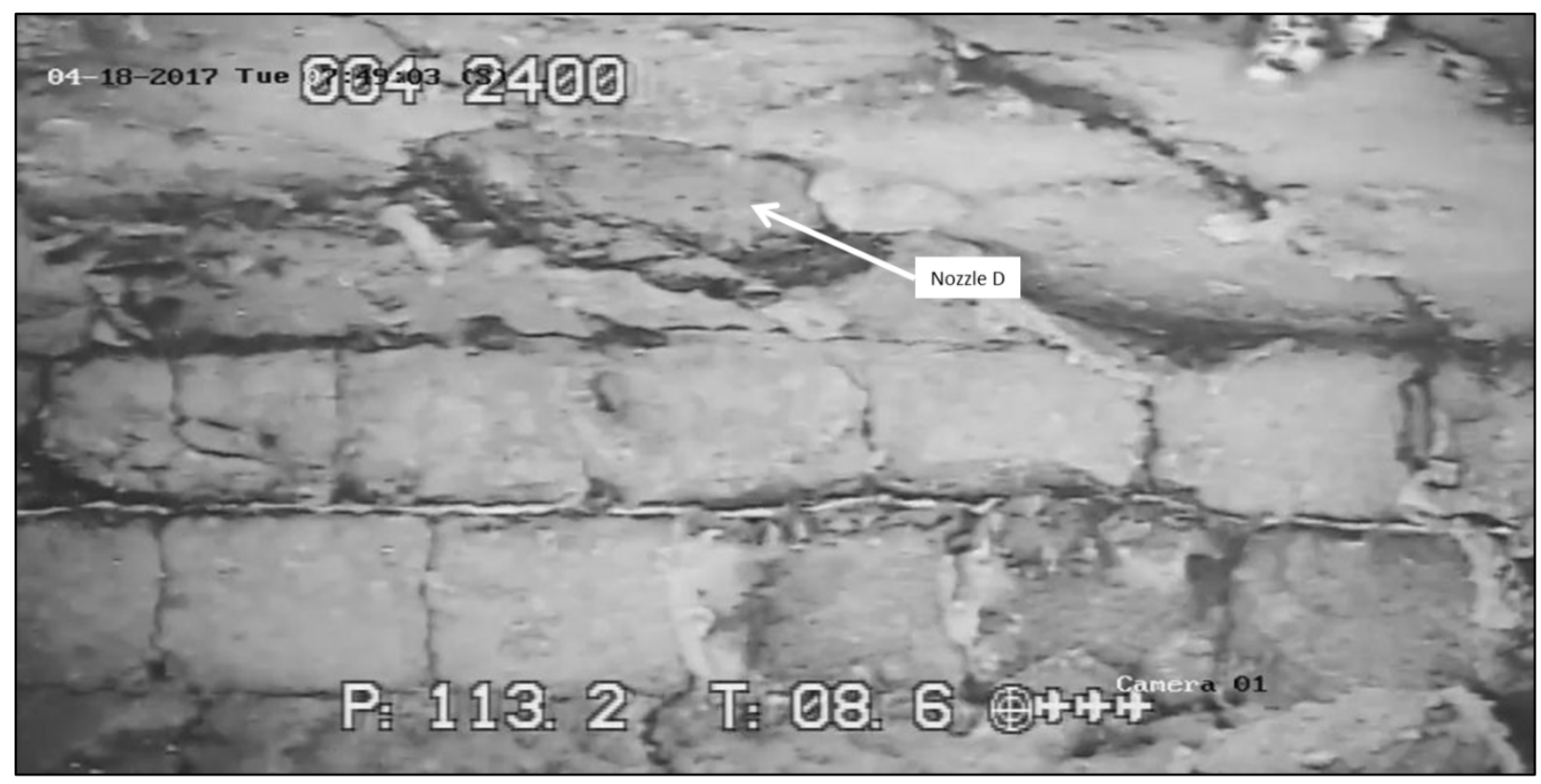

Figure 5-6. Vapor space refractory condition

\subsection{Dome Heaters}

The dome heaters (also referred to as plenum heaters, vapor space heaters, or lid heaters) showed accumulated deposits of material and deformation (sagging). Figure 5-7 shows the top of the four dome heaters on the west side of the melter (sets B and D), including the penetrations through the refractory. Degradation of the refractory and deposits were visible at the penetrations where the dome heaters pass through the refractory walls.

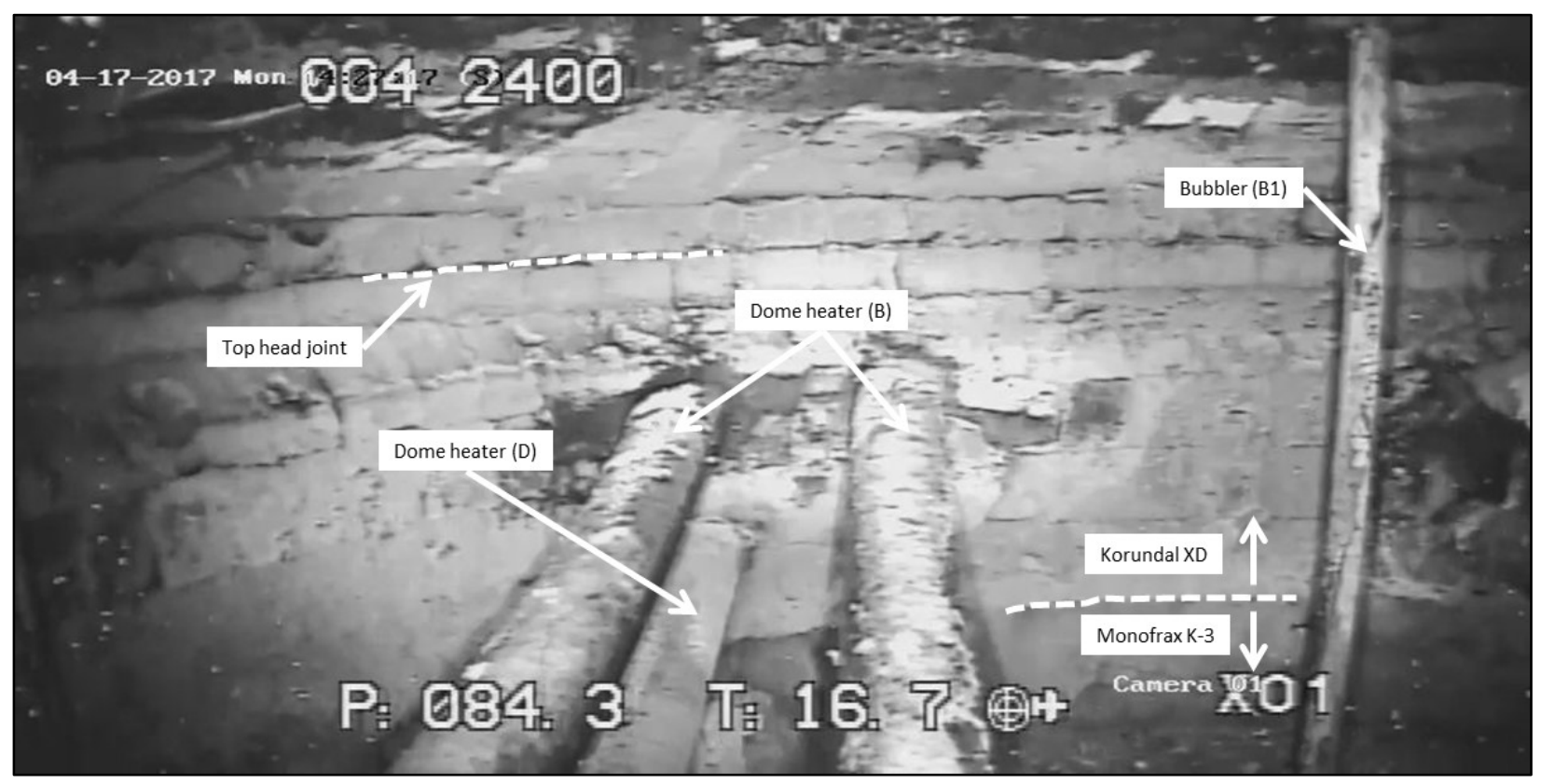

Figure 5-7. Dome heater penetrations, northwest side of melter 
Figure 5-8 provides a closer view of the deposits and refractory degradation around the dome heater penetrations at the northwest side of the melter. This degree of deposition and degradation is to be expected considering the long service life of Melter 2. Figure 5-9 provides a closer view of the accumulated material present on the tops of the dome heaters. Note that the lower pair of dome heaters (D) in this image failed in February 2013. This inspection did not reveal an obvious cause for the failure.

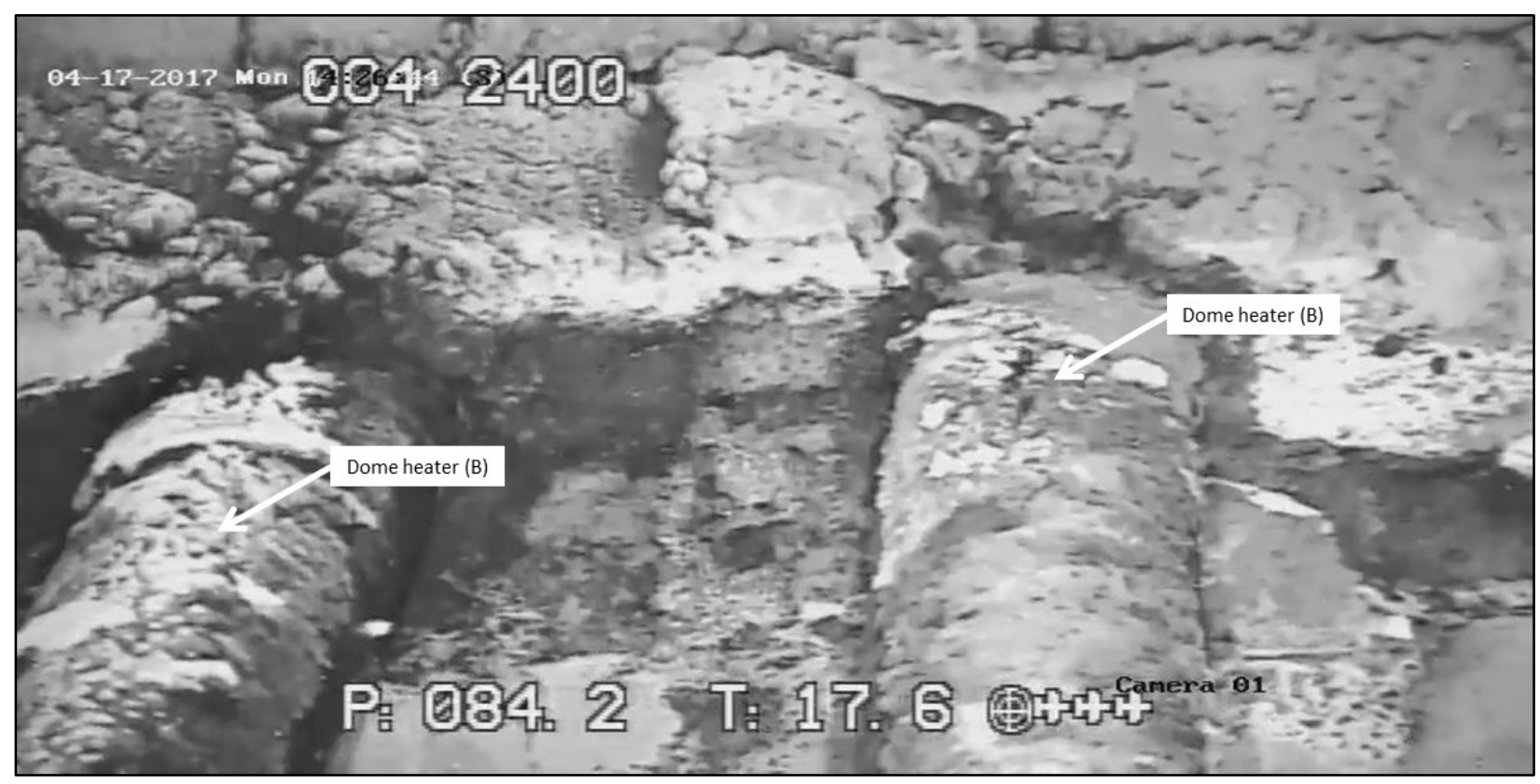

Figure 5-8. Dome heater penetration detail

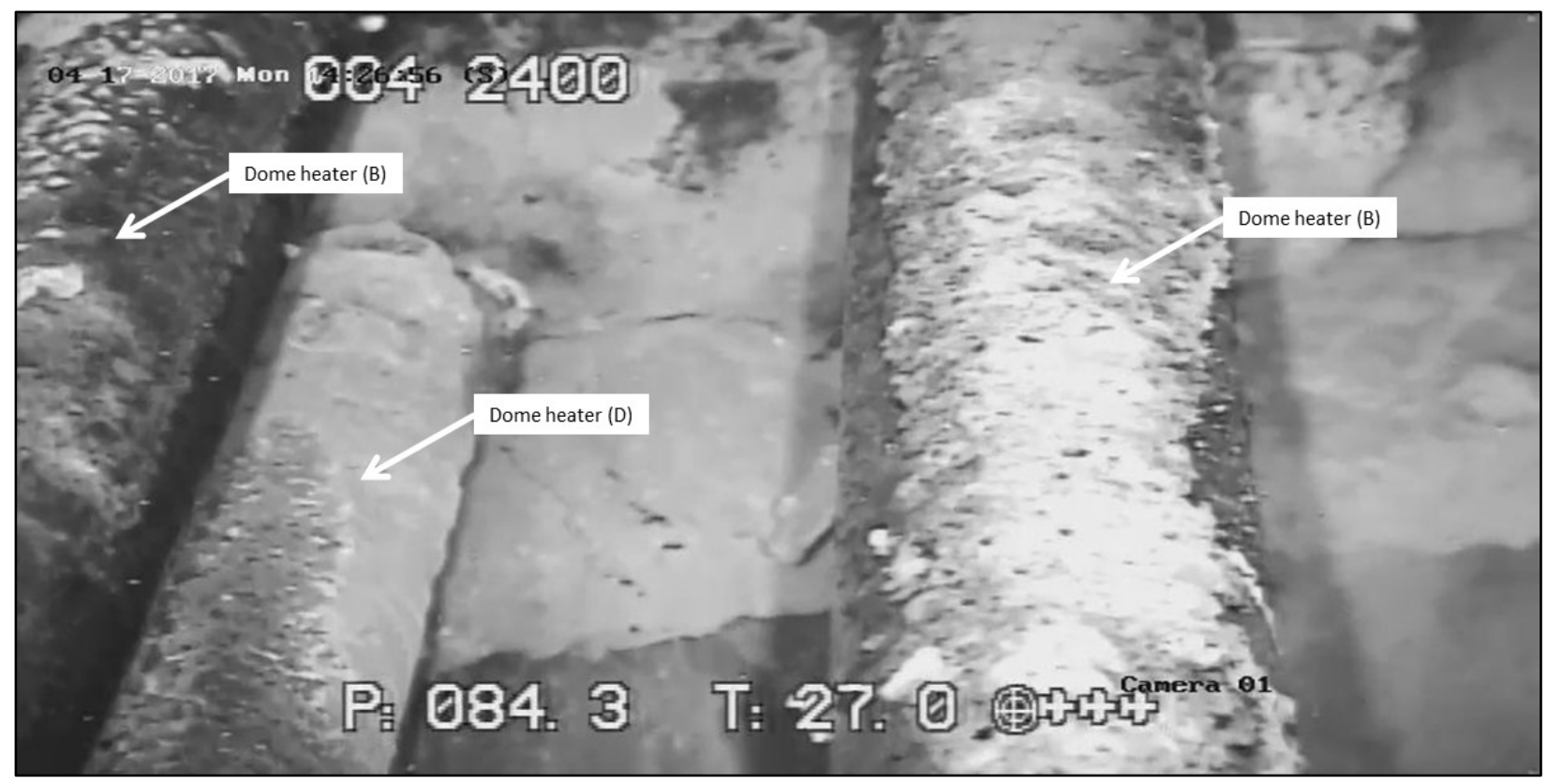

Figure 5-9. Deposits on dome heaters 
Figure 5-10 is an image of the dome heaters (A and C) on the east side of the melter and their penetration through the refractory on the northeast side. Deposits and degradation of the refractory are visible around the penetrations. A closer view of one of the dome heaters at this location is shown in Figure 5-11. The accumulated material on the top of the dome heater (A1) at this location is likely due to the air purge from the borescope nozzle (Nozzle D) above. An alternate view of this location (captured when the camera was inserted through the backup off-gas nozzle, Nozzle T) is shown in Figure 5-12. A closer view of the lower pair of dome heaters (A) is shown in Figure 5-13 at the northeast refractory wall penetration. Again, both degradation of the refractory and accumulation of material are visible at the dome heater penetrations. The inspection of Melter 1 after shutdown identified similar deposits, especially below the off gas film cooler nozzles. ${ }^{2}$

Deposition or accumulation of material may cause multiple issues for operation of the dome heaters. Deposits may serve as insulators causing a hot spot, which can result in distortion of the heater. Deposits can also reduce the amount of heat that is transferred into the vapor space.

Degradation of the refractory at the dome heater penetrations may allow chloride and sulfate salts to condense in areas where the surface temperature is reduced to the $500-600{ }^{\circ} \mathrm{C}$ range. This may leave these areas prone to rapid attack by breakaway corrosion or sulfidation. Closer inspections of these regions was not possible with the available camera. Overall, operation of the dome heaters does not appear to have been significantly hindered by the deposition and refractory degradation.

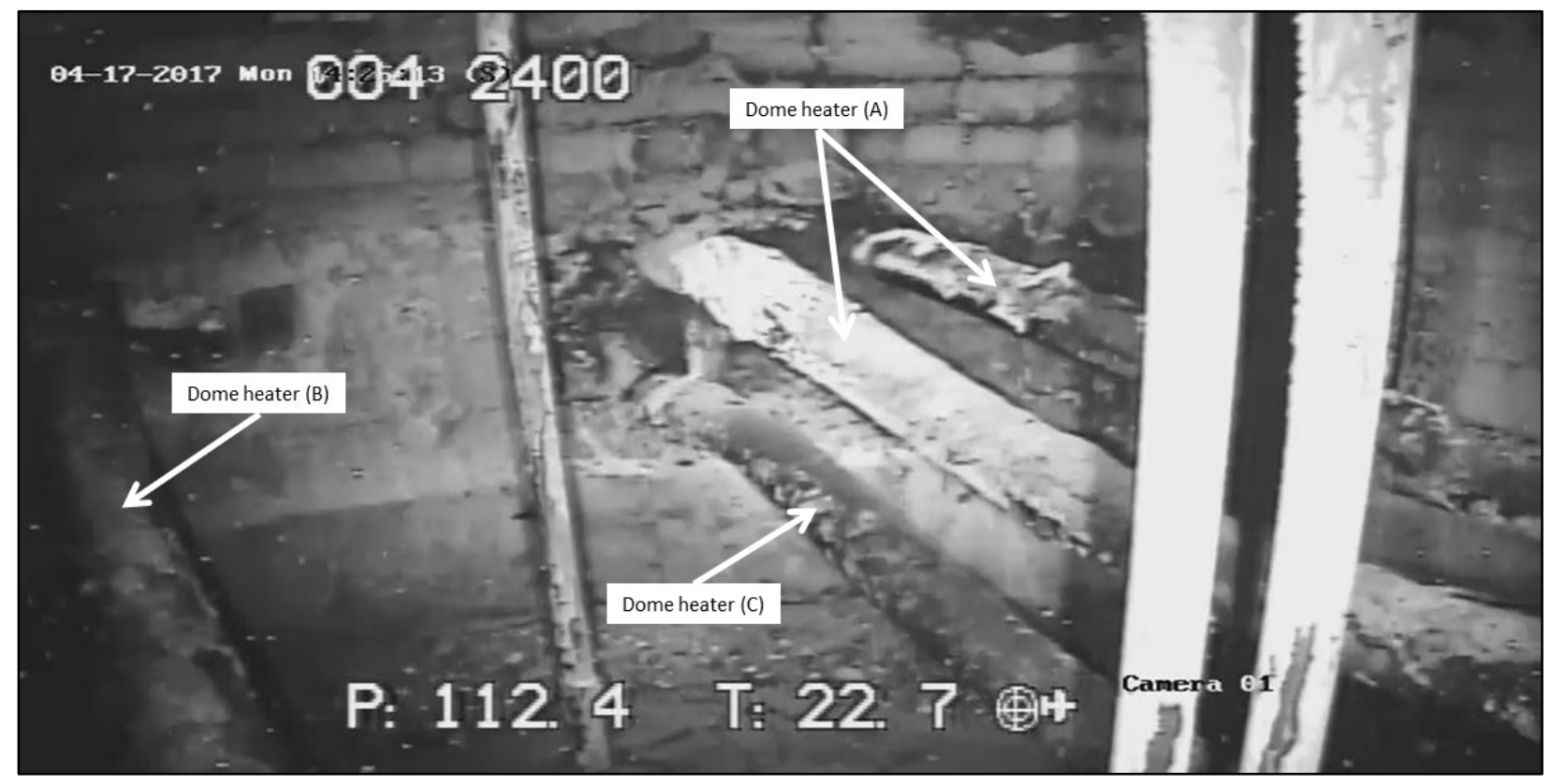

Figure 5-10. Dome heater penetrations, northeast side of melter 


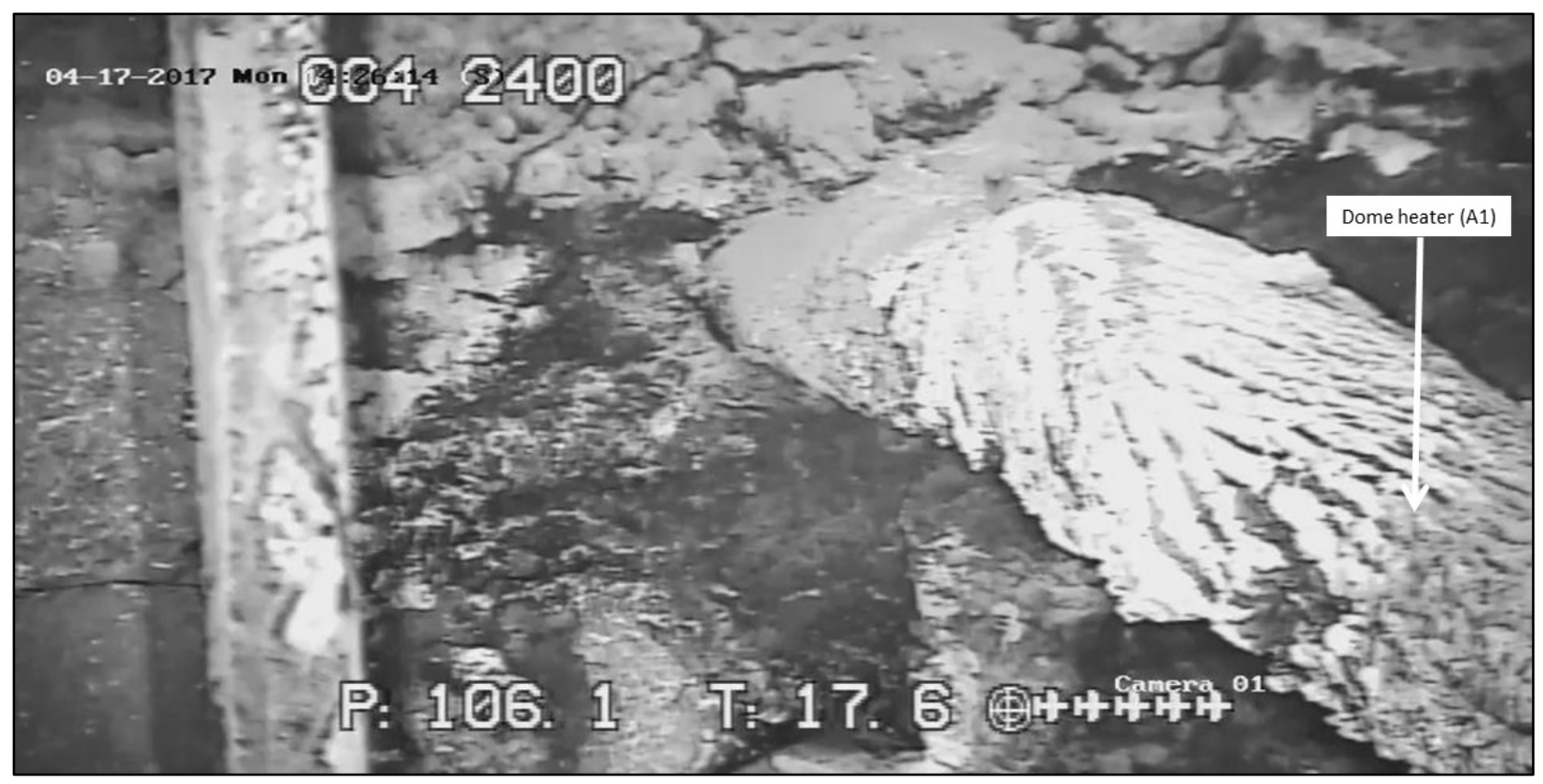

Figure 5-11. Dome heater penetrations, upper pair (A), northeast side of melter

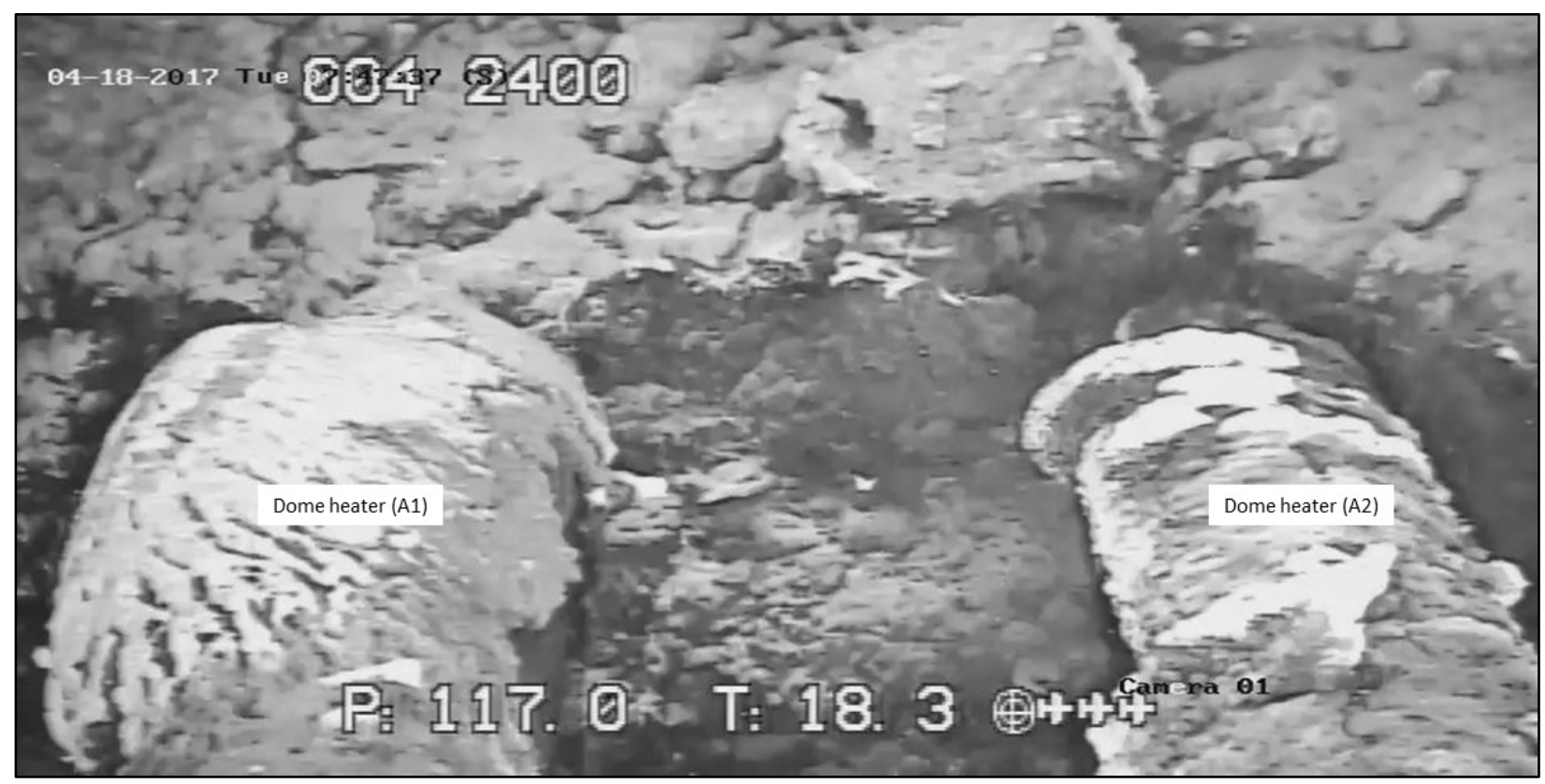

Figure 5-12. Dome heater penetrations, upper pair (A), northeast side of melter, alternate view 


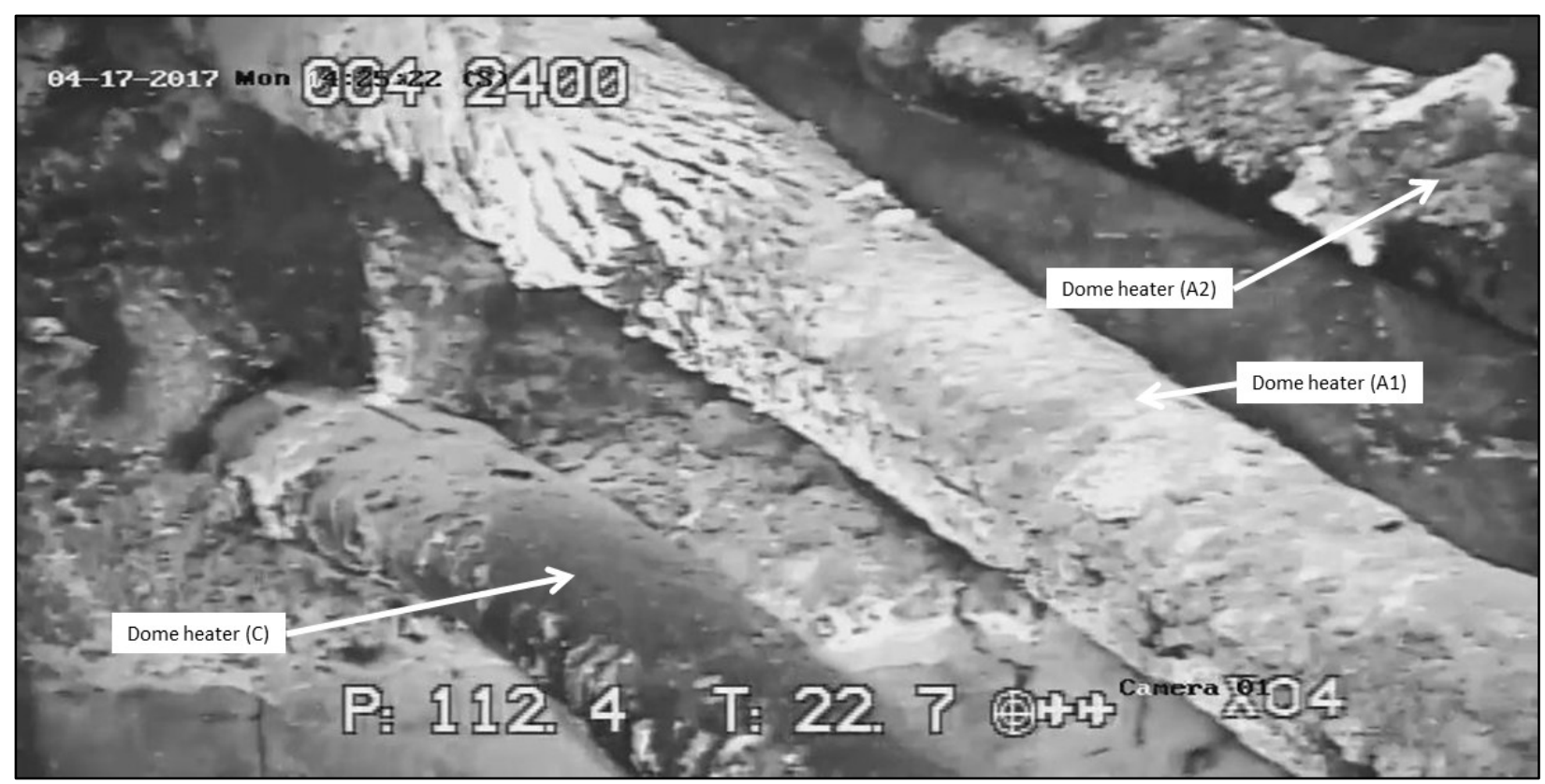

Figure 5-13. Dome heater penetrations, lower pair, northeast side of melter

Figure 5-14 provides a view of deposits and degradation of the refractory around the dome heater penetrations at the southeast side of the melter. The additional deposition seen on the upper pair of dome heaters is likely due to quenching from the purge air entering through the backup off gas film cooler (Nozzle T) above this location. Material condensed in the film cooler may also spall off and accumulate in this area. A closer view of the penetration of the lower pair of dome heaters at this location is provided in Figure 5-15. An alternate view of the deposits on top of the dome heaters at this location is shown in Figure 5-16, where the camera was inserted through the backup off gas nozzle (Nozzle T).

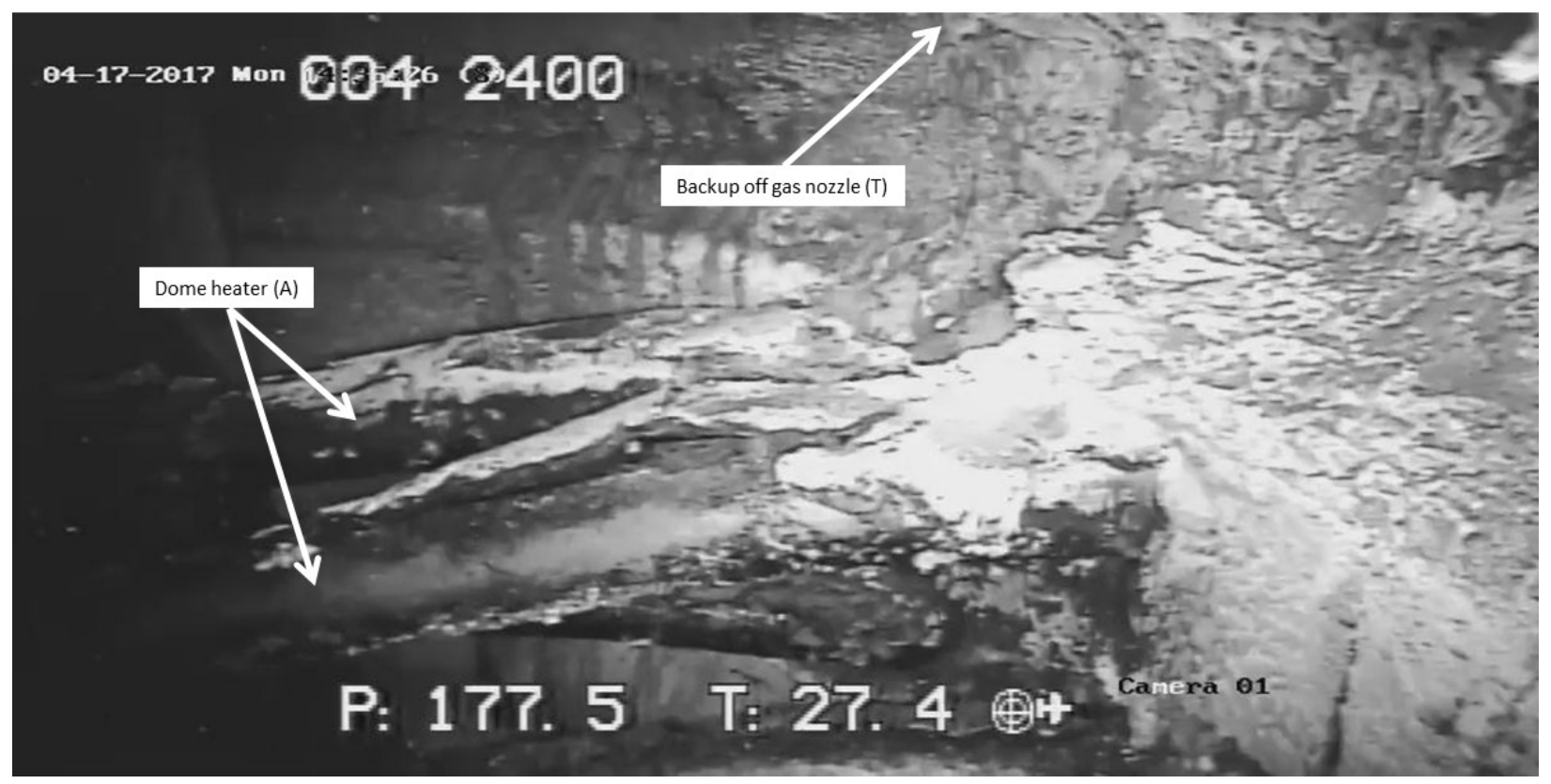

Figure 5-14. Dome heater penetrations, upper pair, southeast side of melter 


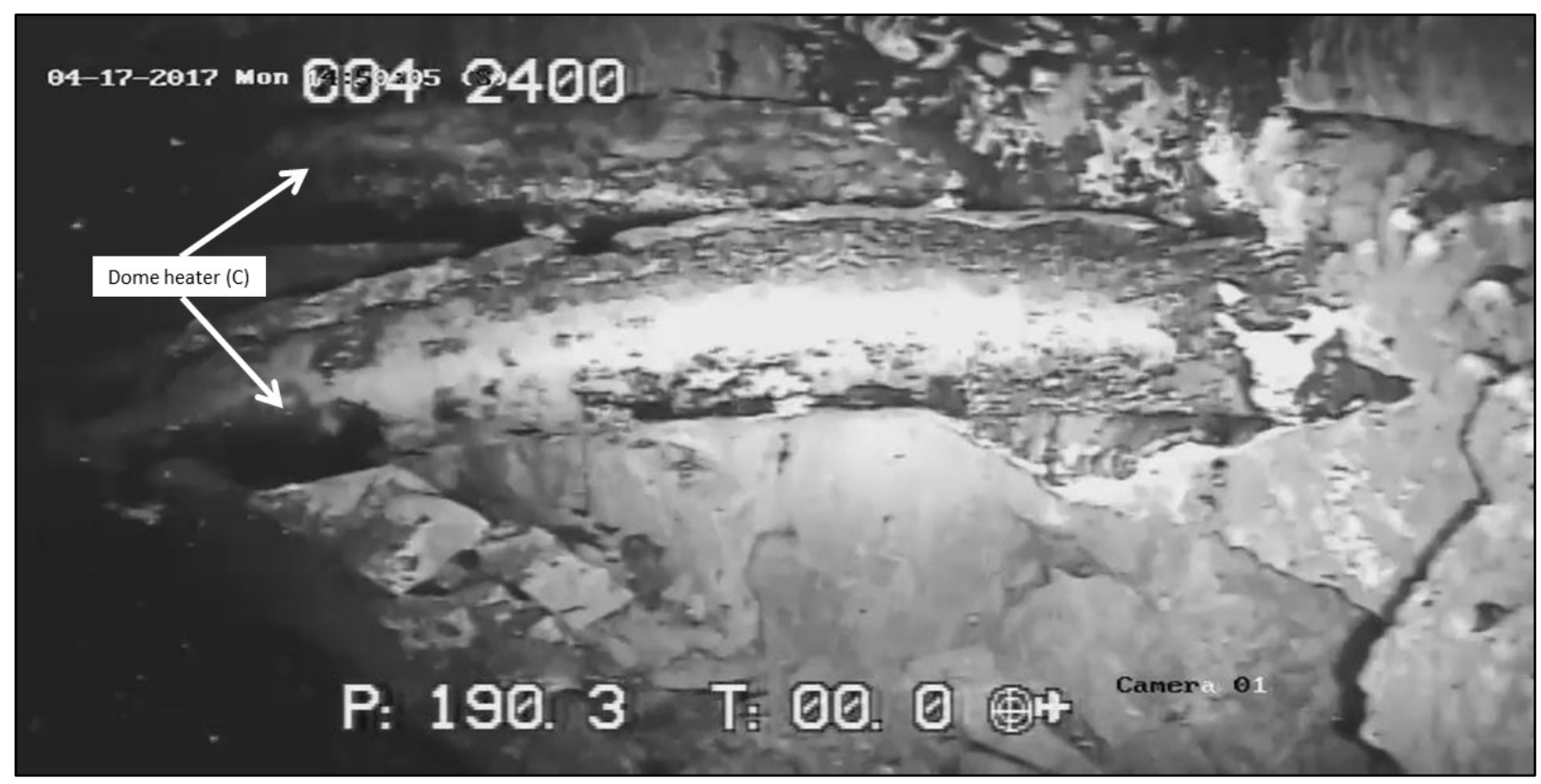

Figure 5-15. Detail of dome heater penetrations, lower pair, southeast side of melter

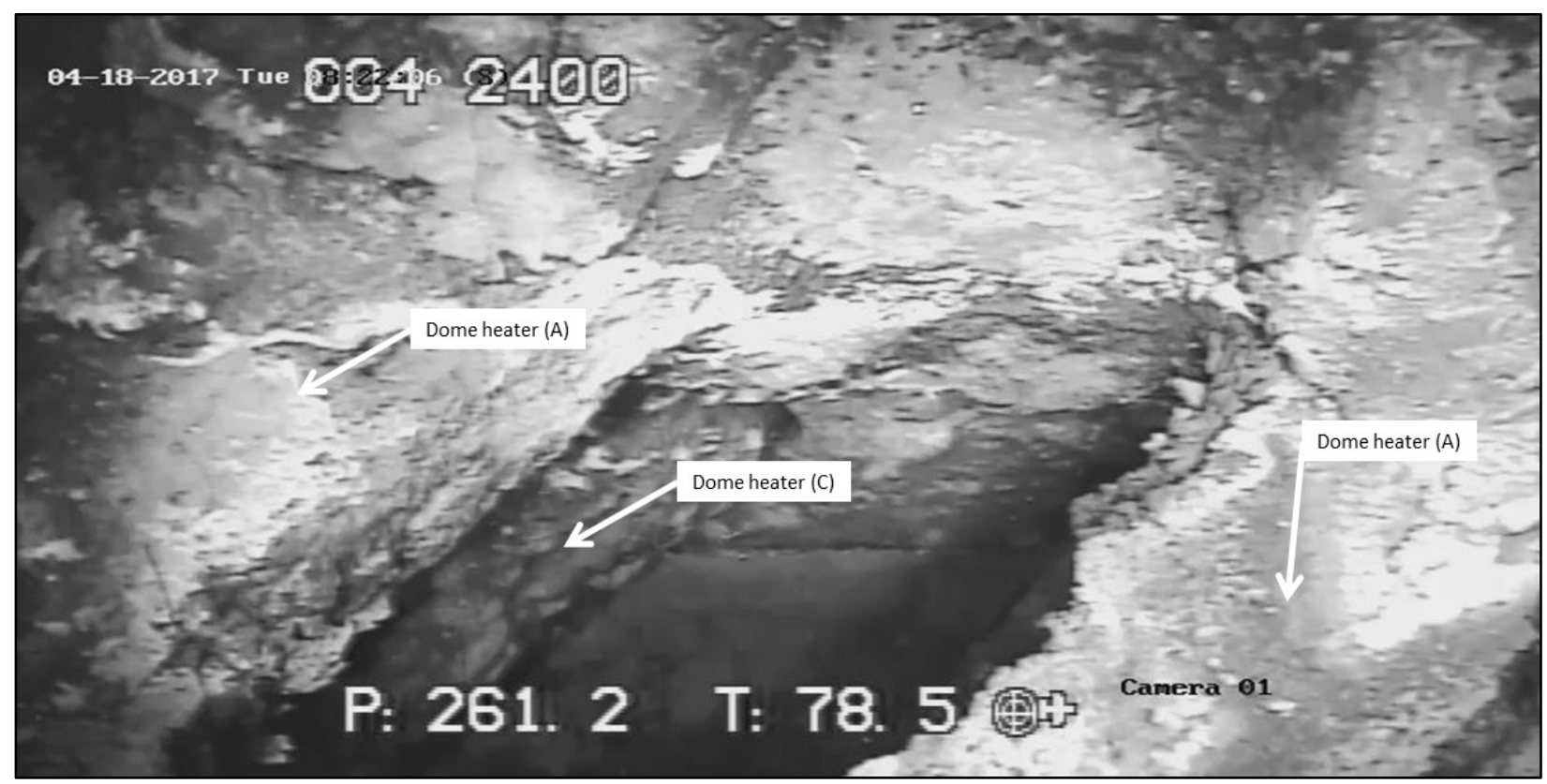

Figure 5-16. Dome heater penetrations, southeast side of melter, view from above

Figure 5-17 provides a view of deposits and refractory degradation around the dome heater penetrations at the southwest side of the melter. The condition of the refractory in this area appeared to be similar to that of the other dome heater penetrations. 


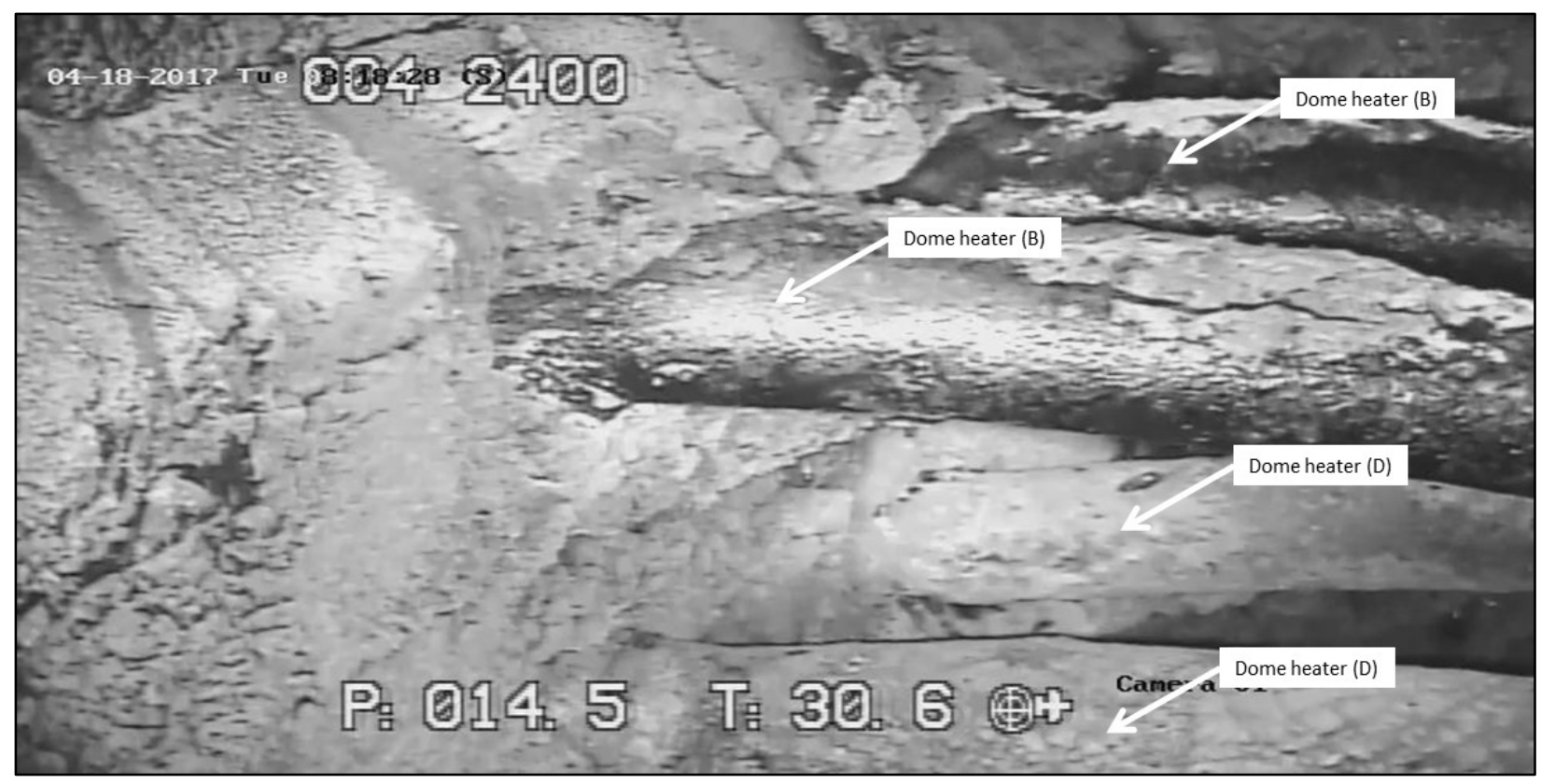

Figure 5-17. Dome heater penetrations, southwest side of melter

Deformation of the dome heaters was observed mainly as downward sagging across the length of the heaters, with some upward bowing near the refractory penetrations. An example of deformation of the upper pair of dome heaters on the east side of the melter is shown in Figure 5-18. Refer to Figure 4-4 for the original condition of the dome heaters. The deformation is likely due to a combination of factors over the service life of the melter, including creep, thermal gradients due to the insulating effects of deposits, and varying degrees of cold cap coverage causing uneven heating (shine) from the melt pool. The dimensions of the dome heaters may also have changed unevenly over time, due to wall thinning from oxidation. In reviewing dome heater operation data, there was a discernable increase in dome heater resistance over the life of Melter 2. However, this increase and the deformation of the dome heaters did not appear to detract from their operation, based on power consumption and the ability to control the vapor space temperature. Figure 5-19 shows similar deformation of the dome heaters on the west side of the melter. 


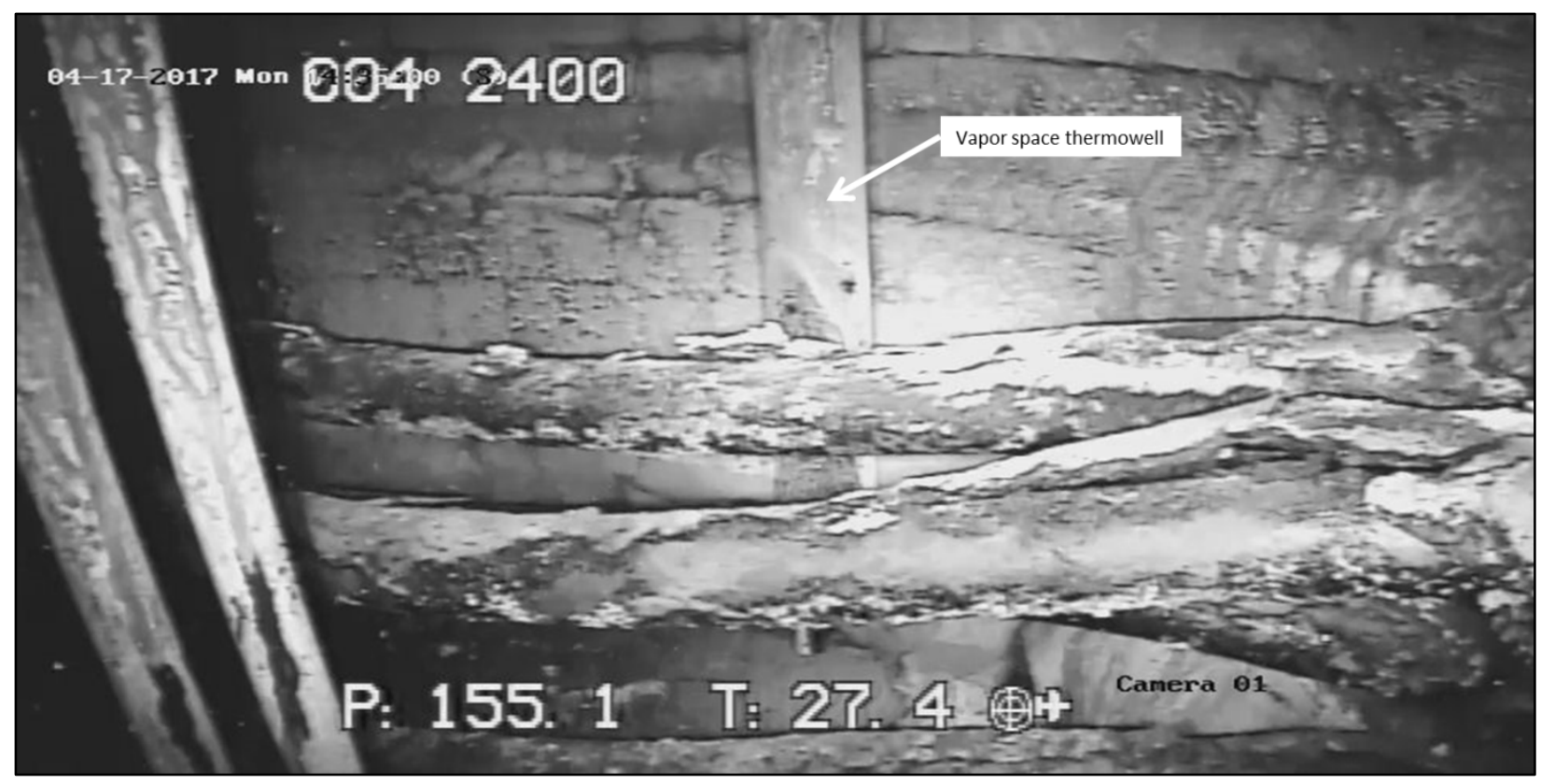

Figure 5-18. Deformation of dome heaters, east side of melter

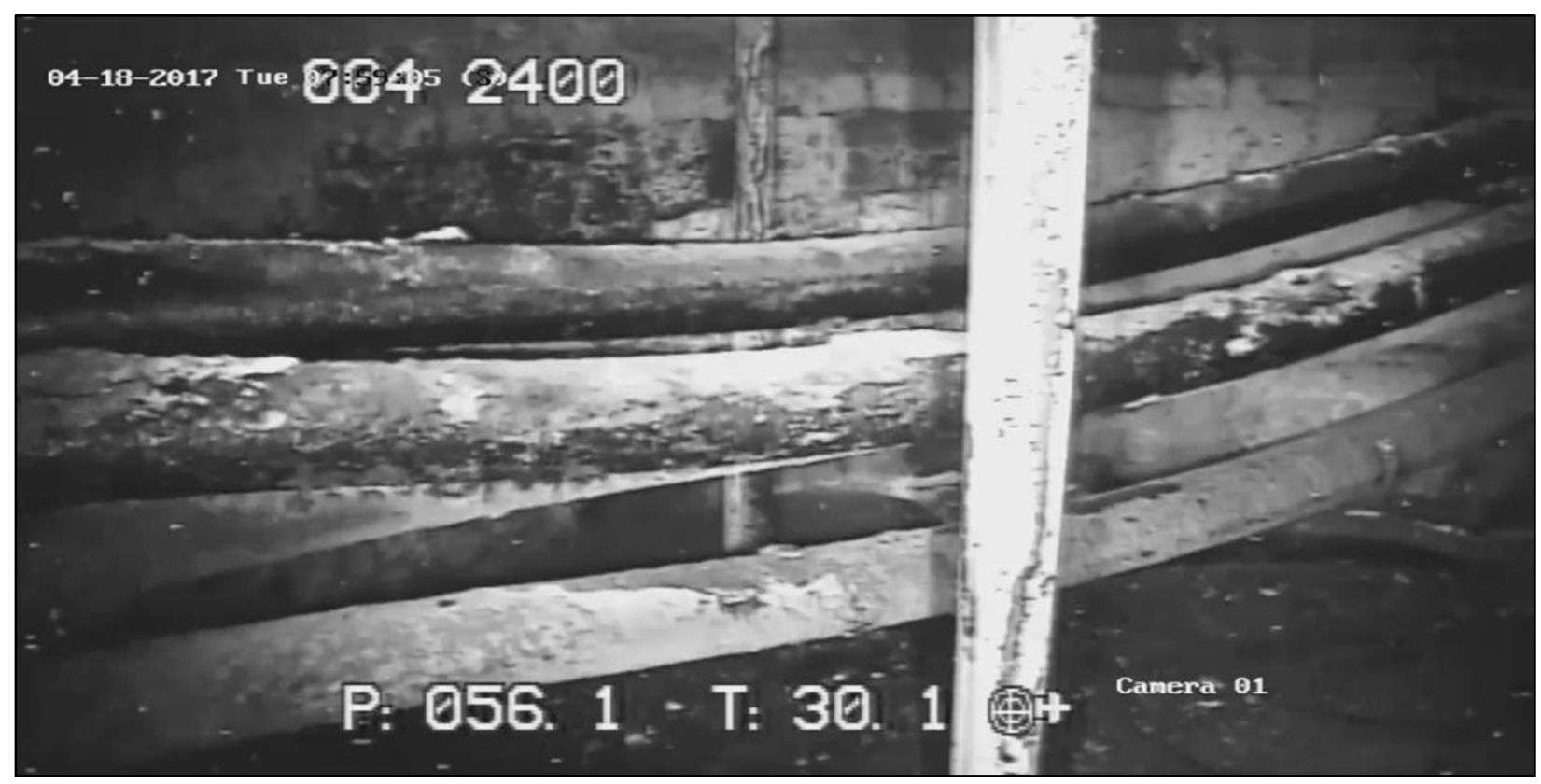

Figure 5-19. Deformation of dome heaters, west side of melter

Further observation of the dome heater deformation was obtained by orienting the camera nearly parallel with the long axis of the heaters, as shown in Figure 5-20. The upper dome heaters on the west side of the melter appear to have sagged by an amount approximately equivalent to their diameter. The lower pair of dome heaters with light colored deposits is the "D" heaters that failed in February 2013. Deformation of these heaters was observed by lowering the camera further, Figure 5-21. 


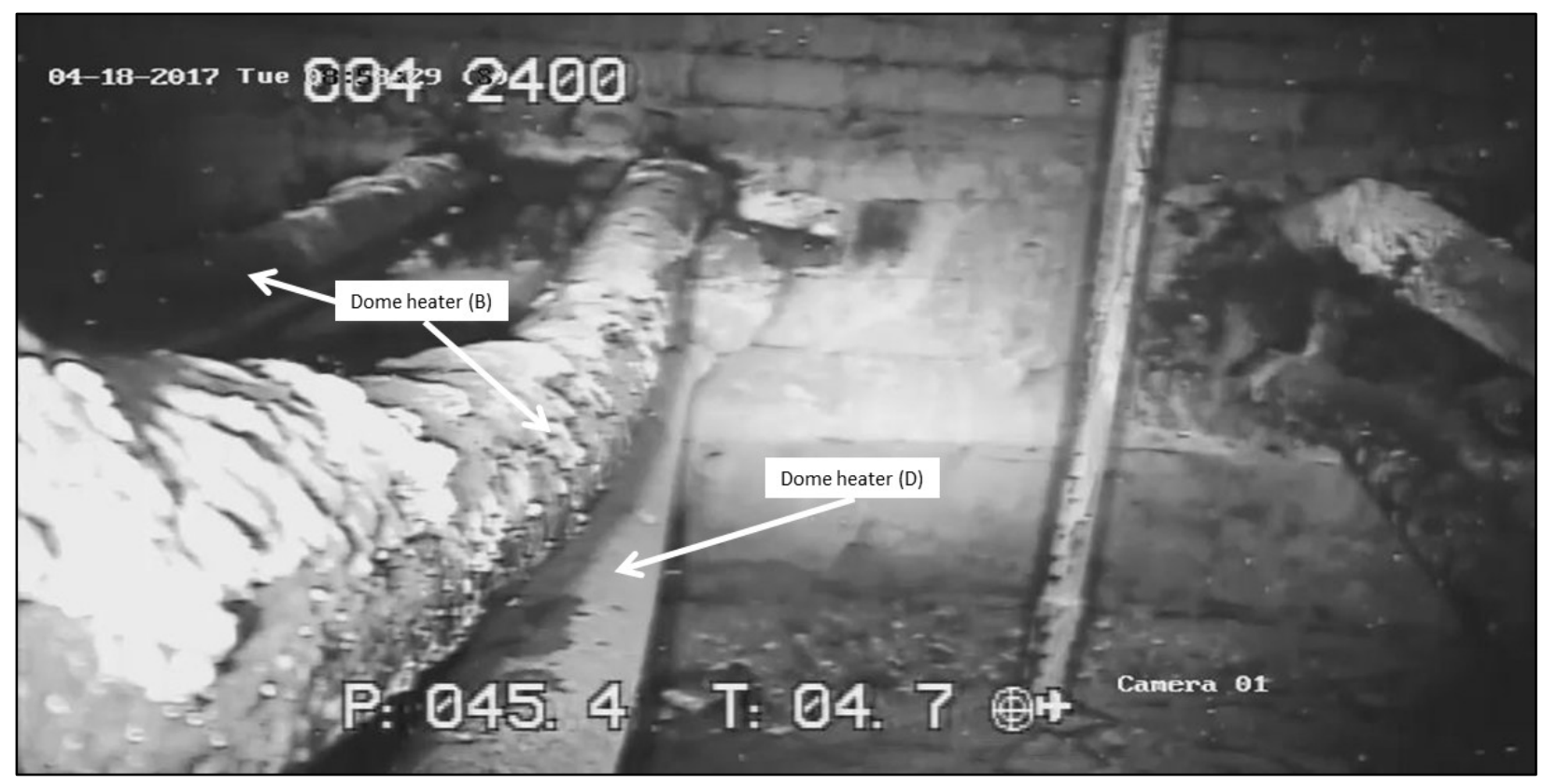

Figure 5-20. View along dome heaters showing deformation, west side of melter

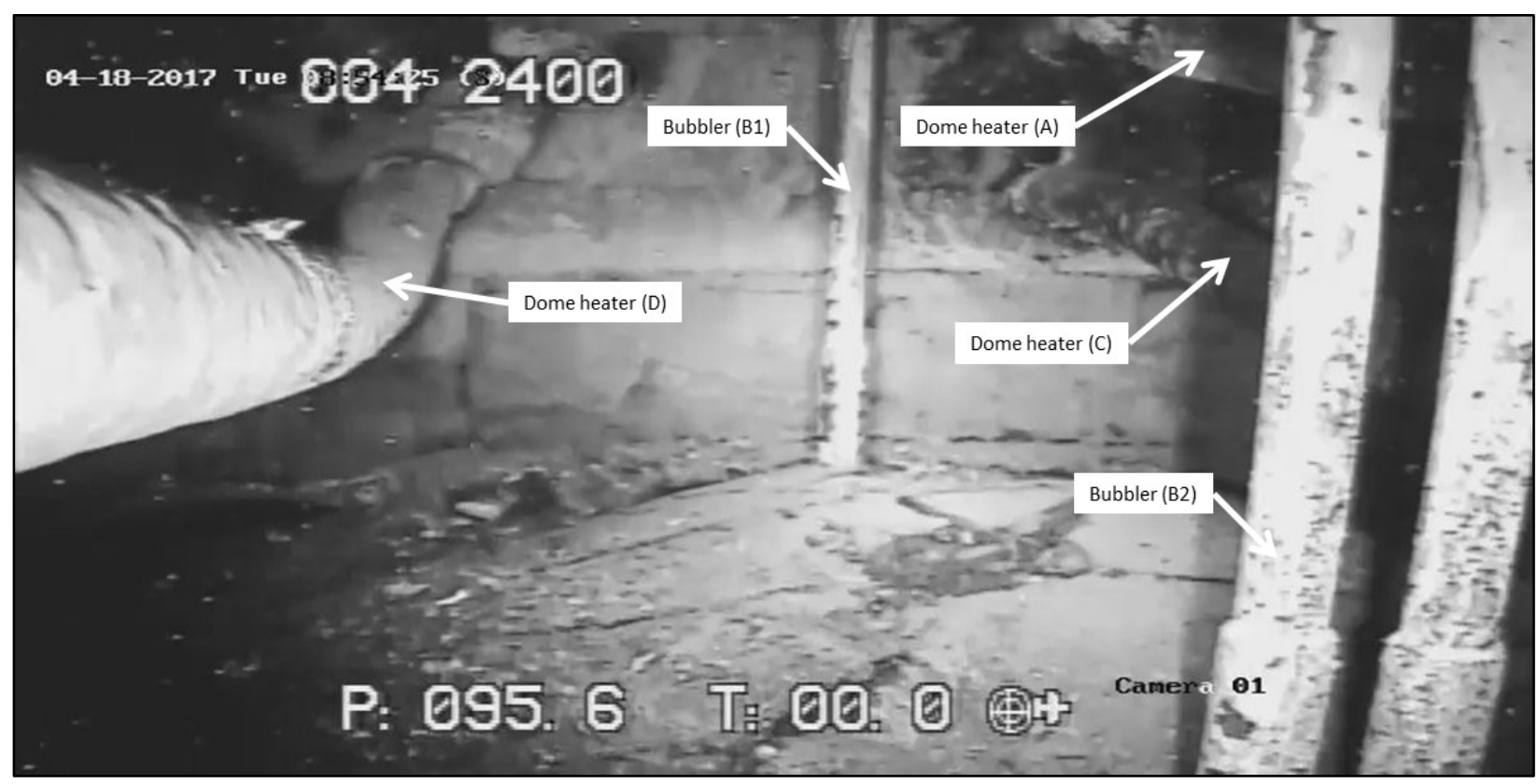

Figure 5-21. View along dome heaters showing deformation, lower pair, west side of melter

\subsection{Electrodes and Glass Contact Refractory}

Melter 2 was shut down with a full inventory of glass, which prevented inspection of the melt pool electrodes. However, the top portions of the upper electrodes remained visible. The top of the L1 electrode at the southeast side of melter is visible in Figure 5-22. Pieces of what appear to be refractory material are visible behind the electrode, shown from a lower angle in Figure 5-23. It appears that these pieces spalled 
off of the refractory wall during cooling of the melter, as they would otherwise have been expected to fall into the melt pool. As shown in the drawing in Figure 5-24, the back of the electrode was originally up against the refractory wall. From Figure 5-22 and Figure 5-23, it appears that the refractory has worn or spalled away, leaving a gap between the electrode and the refractory wall that may be filled with glass. The width of the gap appears to be approximately equal to the thickness of the electrode ( 3 inches). The missing $\mathrm{K}-3$ at this location is an un-retained "shelf" of K-3 formed as a result of producing the flat refractory surface for mounting of the electrodes (Figure 5-25). Similar significant material spalling or loss was not observed elsewhere around the circumference of the melter. Figure 5-26 shows the L1 electrode as viewed from above, via inserting the camera down through the backup off gas nozzle (T). The refractory pieces are again visible.

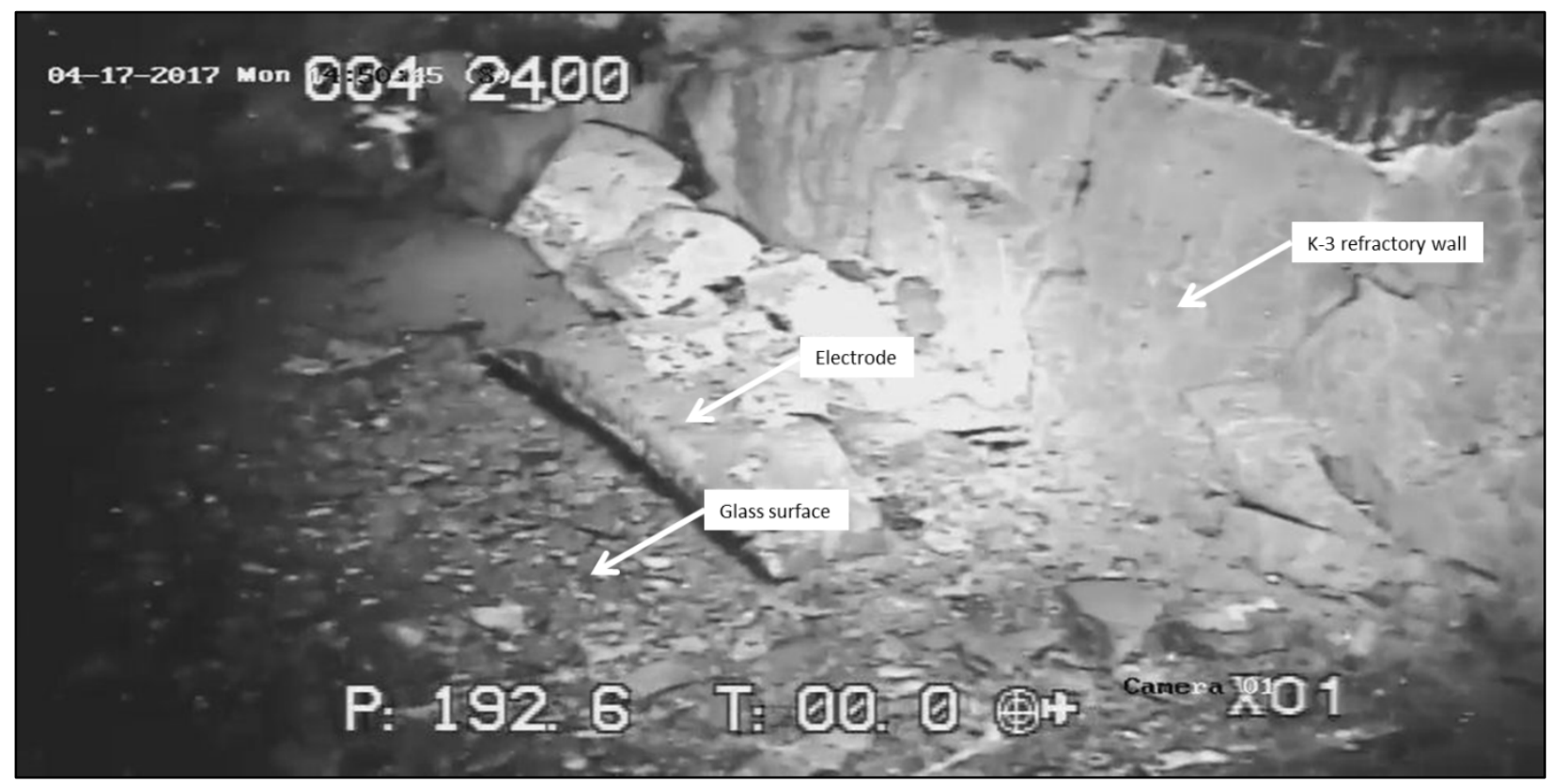

Figure 5-22. Upper electrode, southeast side of melter 


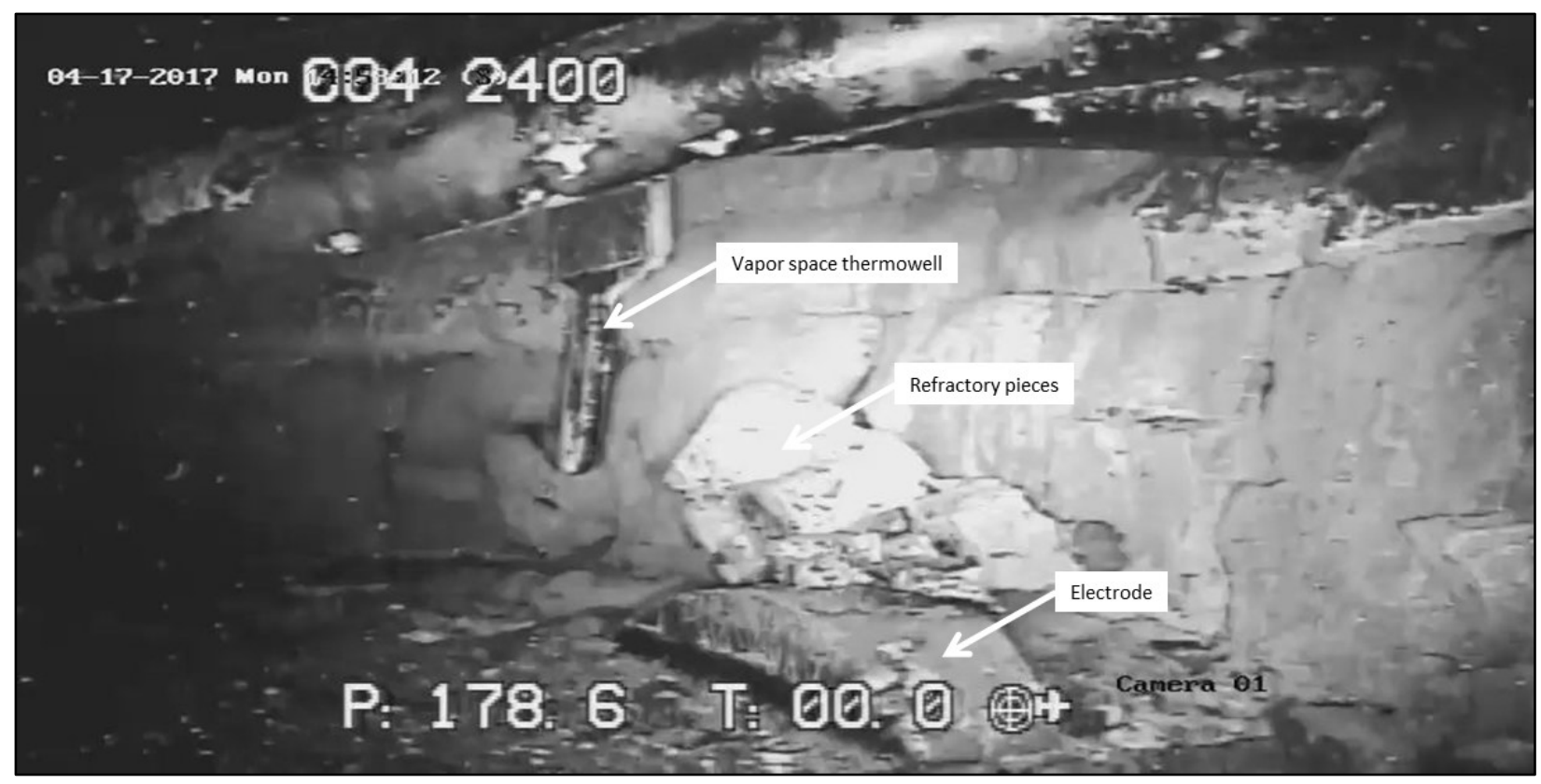

Figure 5-23. Refractory pieces visible behind upper electrode 


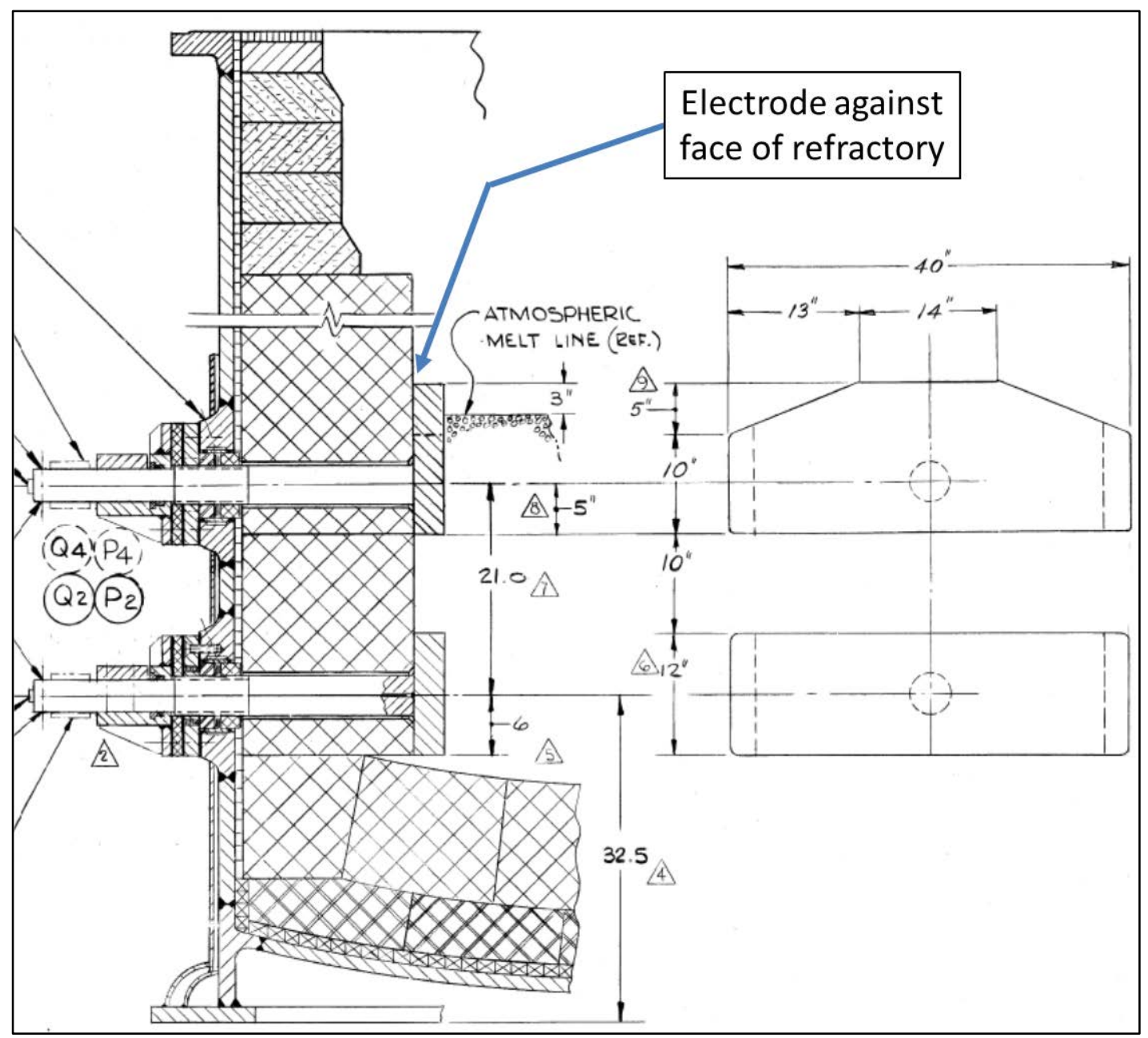

Figure 5-24. Original electrode and glass contact refractory configuration (adapted from drawing W728051) 


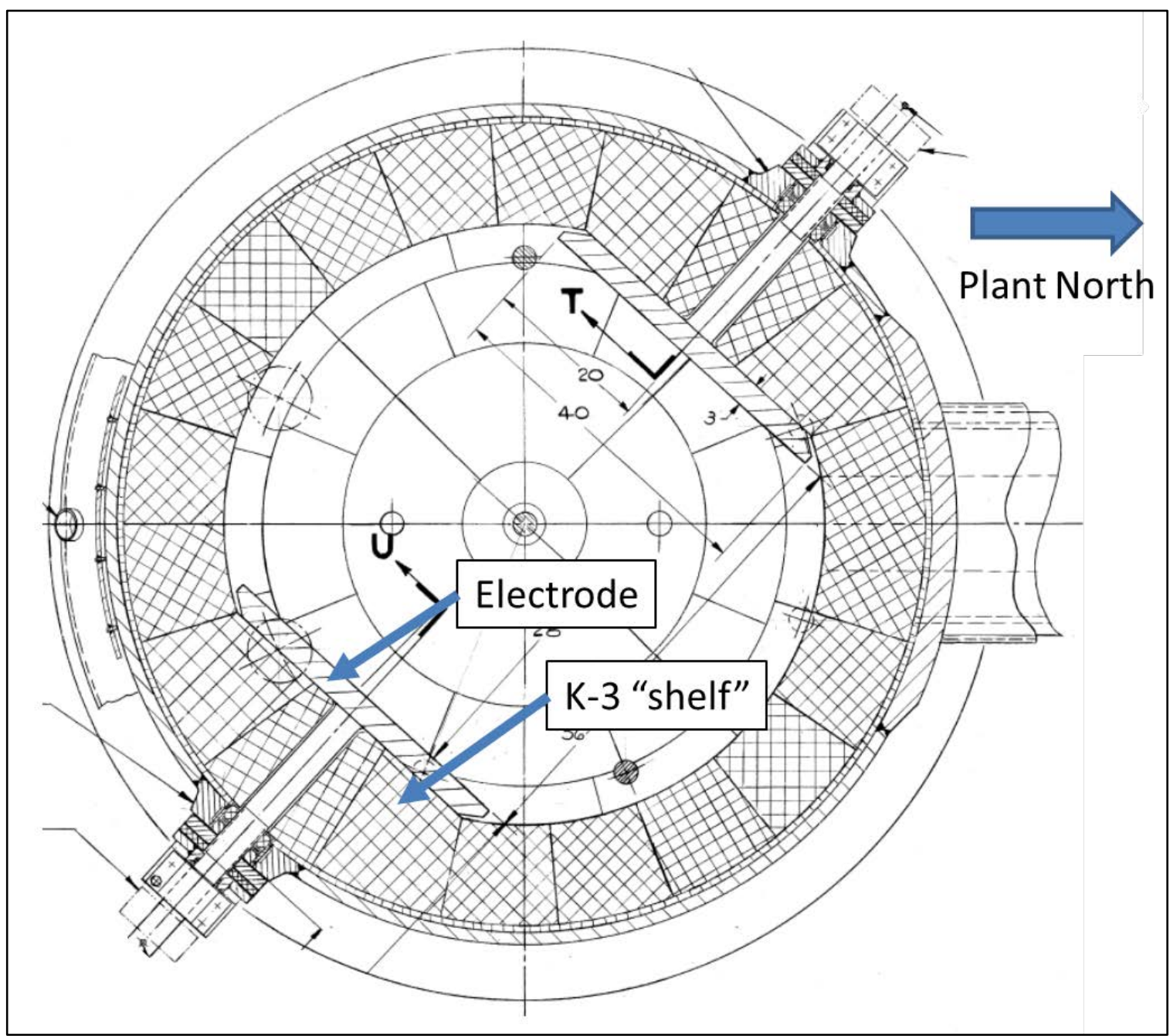

Figure 5-25. Top down view of original electrode and glass contact refractory configuration showing K-3 refractory “shelf” behind upper electrode (adapted from drawing W728051) 


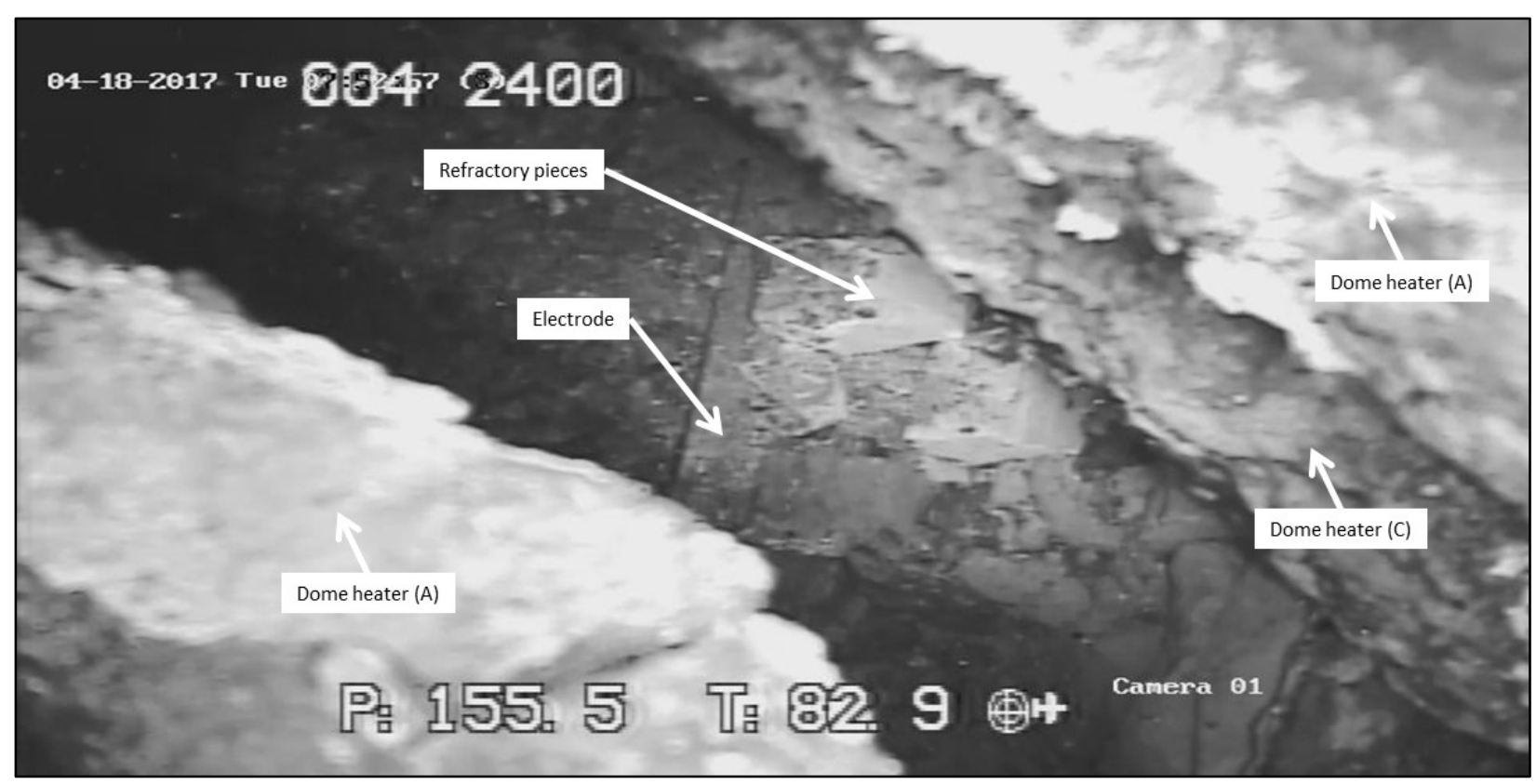

Figure 5-26. Upper electrode, southeast side of melter, viewed from above

A closer view of the top of the L1 electrode is shown in Figure 5-27. Small cracks are visible on the top surface of the electrode. These cracks may be in the layer of deposits that has formed on top of the electrode. It was not clear from this view whether they penetrate into the Inconel 690. Figure 5-28 shows an alternate view where a relatively large crack is visible and appears to penetrate into the electrode. The orientation of these cracks is consistent with stress in the electrode due to its central support point and direction of apparent sagging/yielding. These cracks may be the result of a series of degradation mechanisms. A significant degree of internal oxidation is expected on the upper surface of the electrode since it is consistently hot during melter operation and exposed to air in the vapor space. Diffusion of chromium along the grain boundaries and out of the electrode on this surface may have also occurred, resulting in the formation of a relatively large volume of internal voids and allowing intergranular attack. ${ }^{3}$ These in turn act as stress concentrators, such that as the electrode creeps (sags) it will crack along these internal defects. The properties of the electrodes are likely to be significantly different from those of the original Inconel 690 alloy, as a result of chromium diffusion, oxidation, tremendous grain growth, and formation of precipitates at the grain boundaries. 


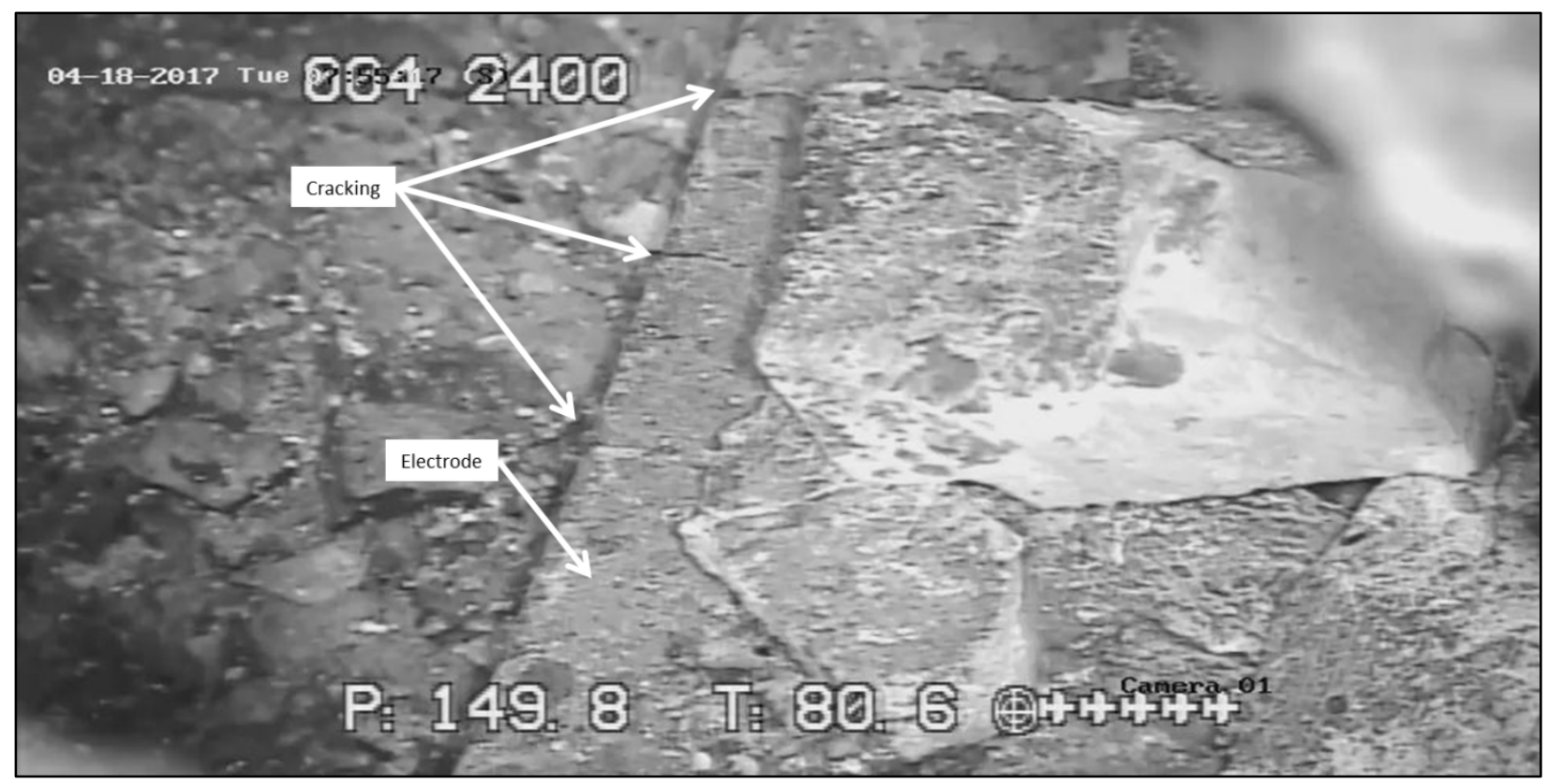

Figure 5-27. Detail view of cracks visible on top of upper electrode, southeast side of melter

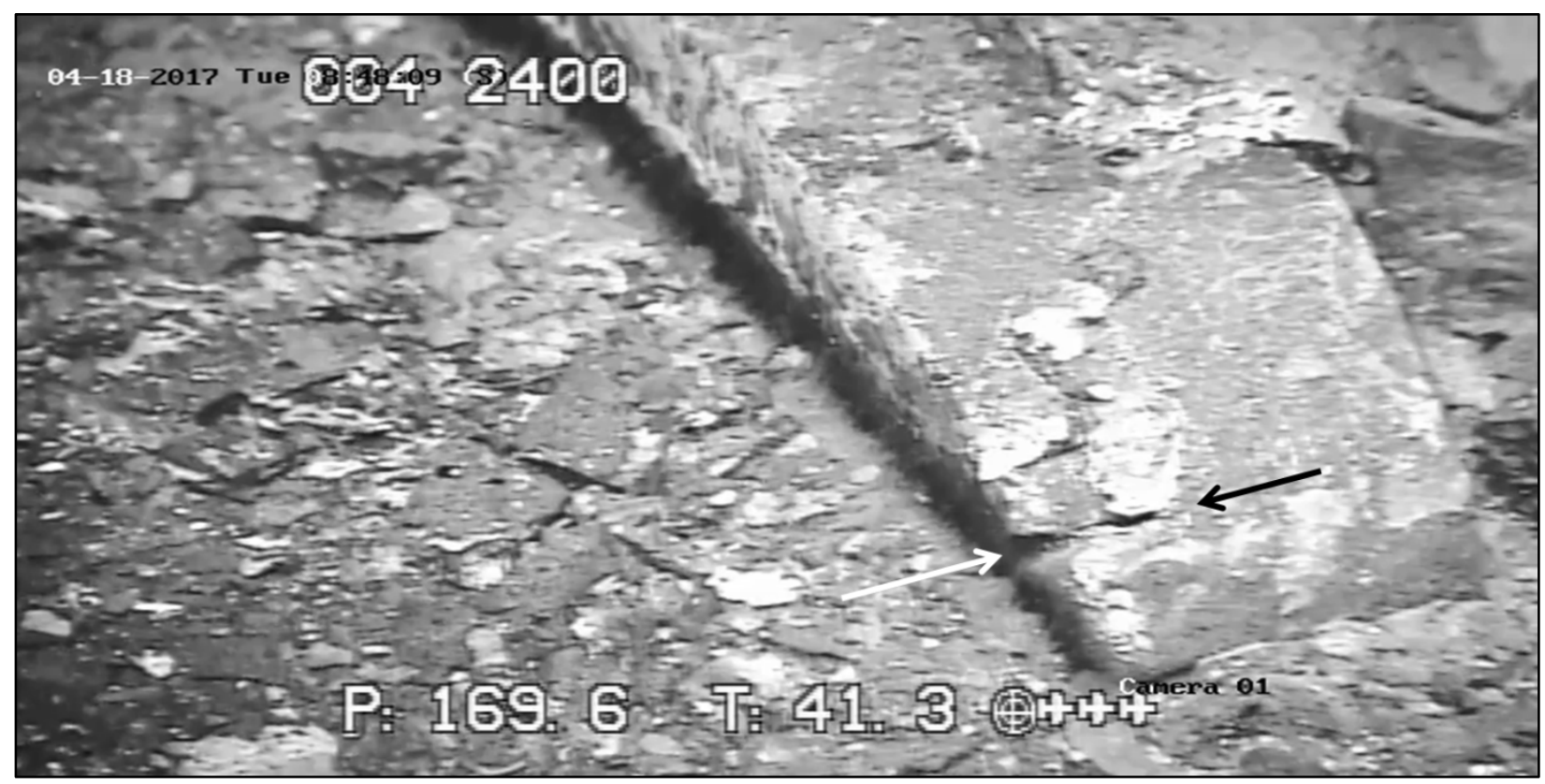

Figure 5-28. Larger crack visible on top of upper electrode, southeast side of melter

A view of the top portion of the L3 electrode at the northwest side of the melter is shown in Figure 5-29. A closer view is provided in Figure 5-30. Deposits are again visible on the electrode. There appears to be some deformation (slumping) of the electrode relative to its original shape, as depicted in Figure 5-31. This is not unexpected given the relatively long service live of Melter 2. 


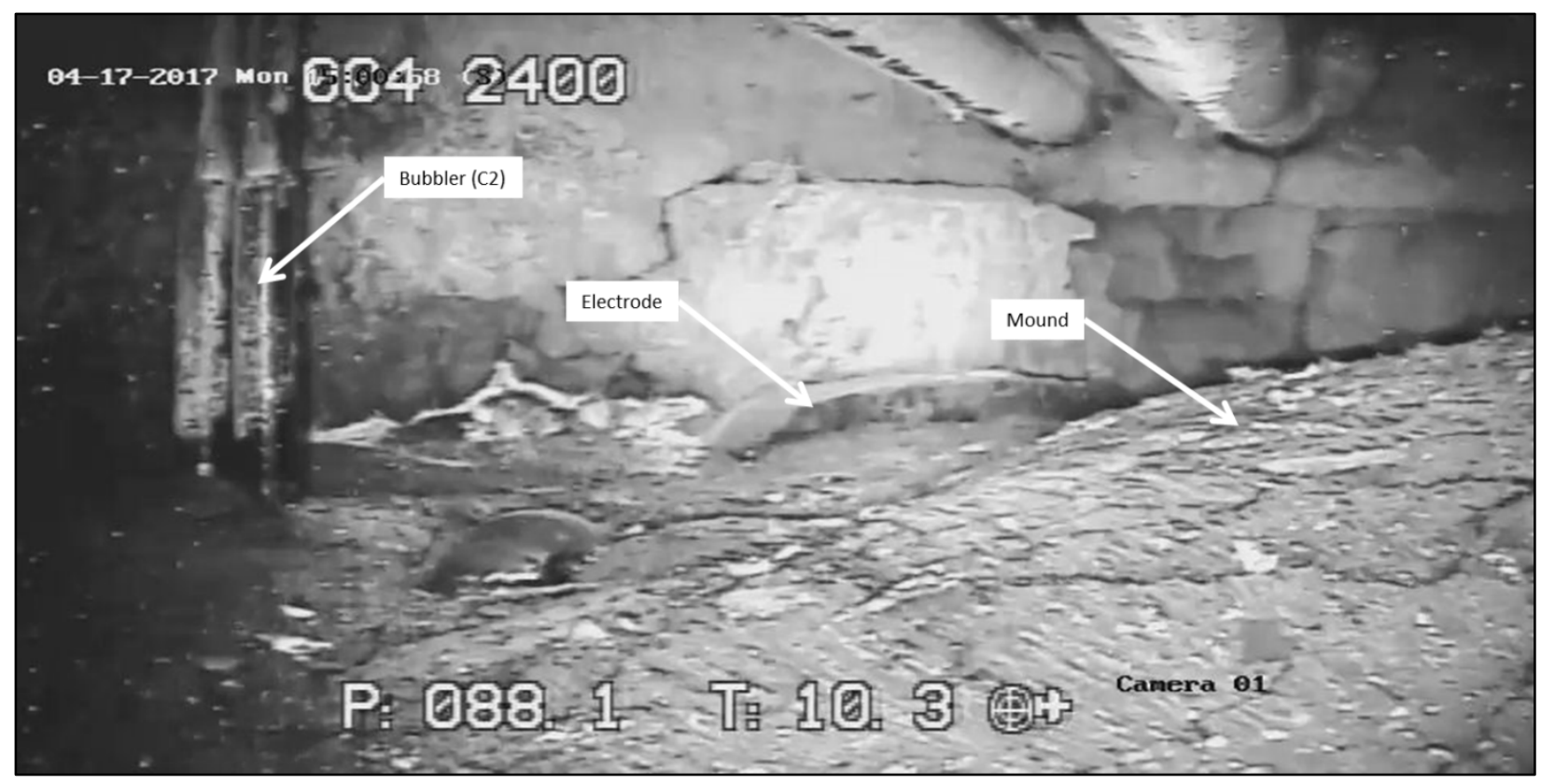

Figure 5-29. Upper electrode (L3), northwest side of melter

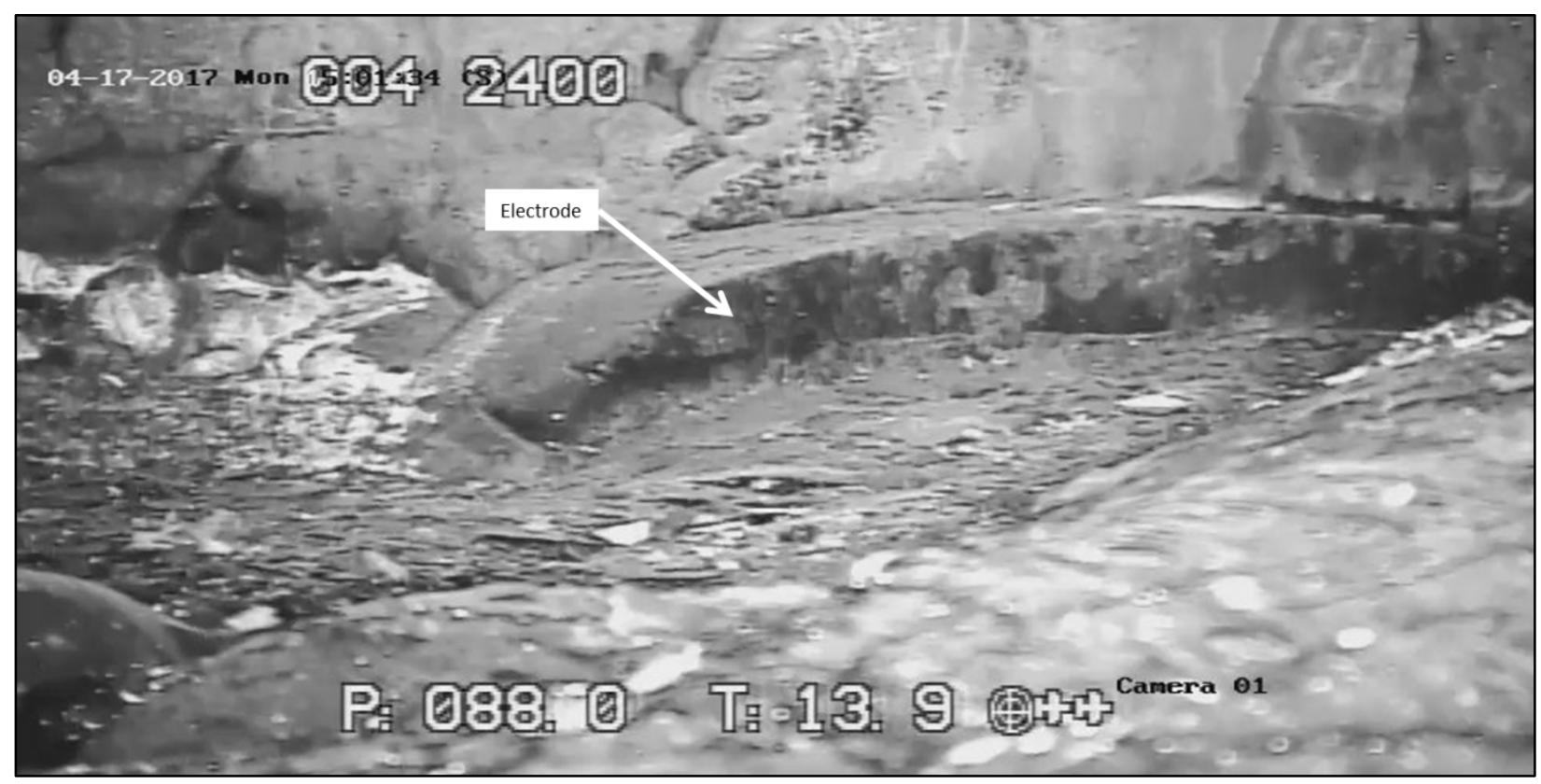

Figure 5-30. Detail view of upper electrode (L3), northwest side of melter 
SRNL-STI-2017-00428

Revision 0

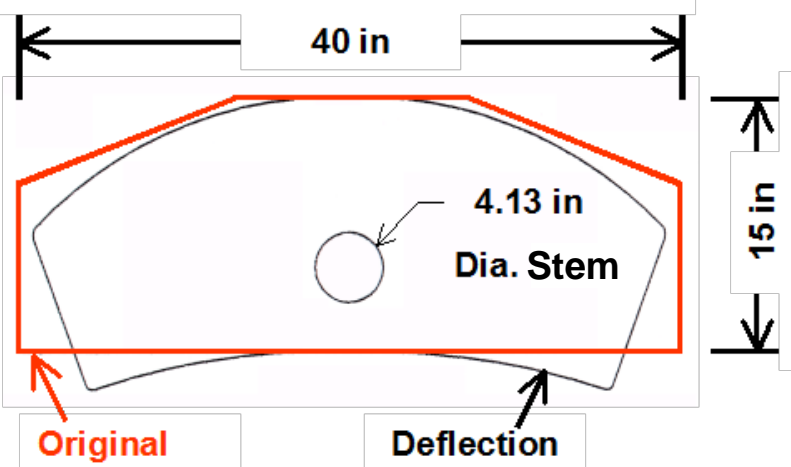

Figure 5-31. Approximation of observed upper electrode slumping (black outline) relative to original electrode shape (red outline)

Another view of the L3 electrode is shown in Figure 5-32. Note that the edges of the electrode appear to have remained fairly sharp. However, this may mask internal degradation via the mechanisms described earlier.

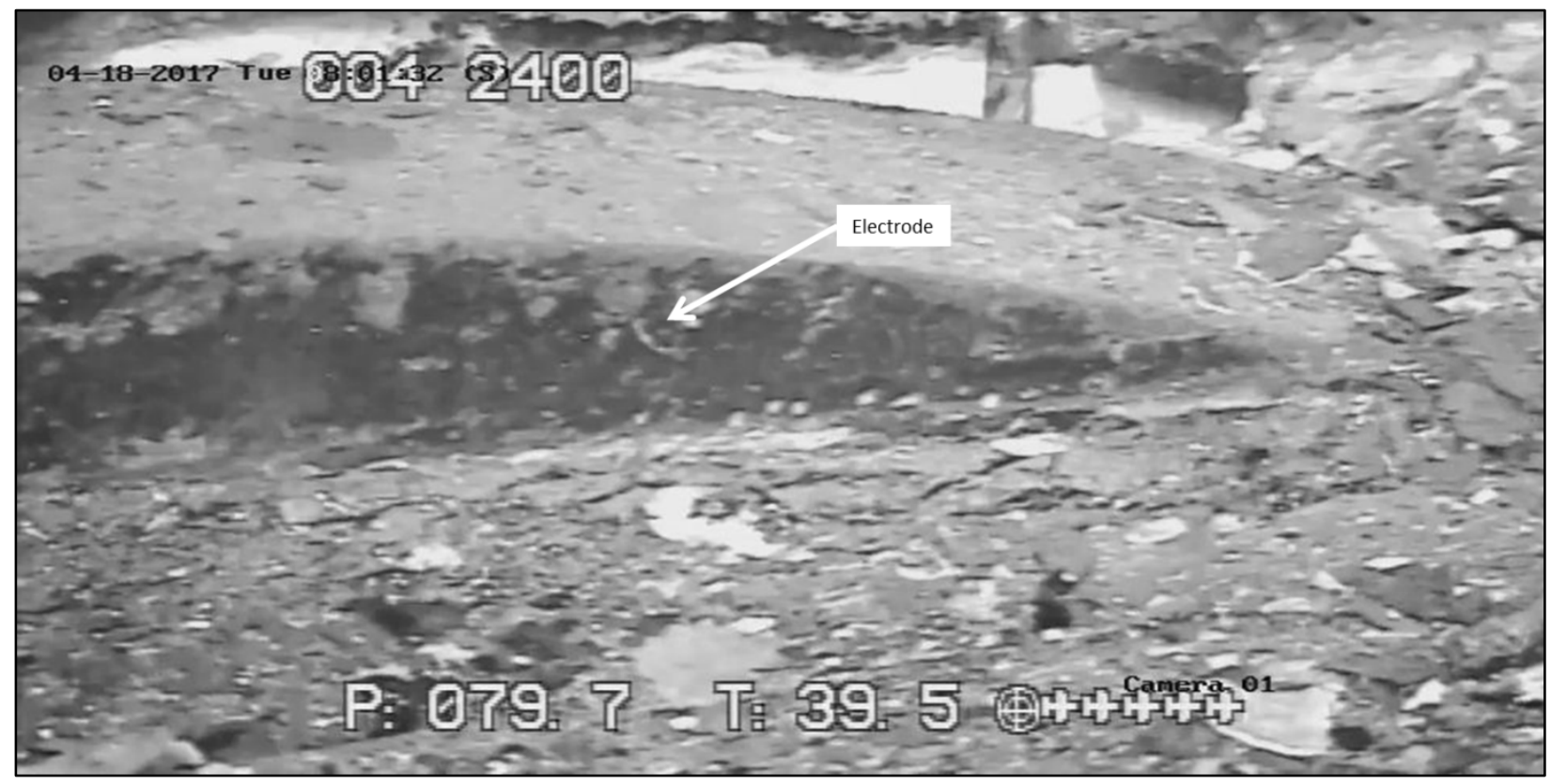

Figure 5-32. Second detail view of upper electrode (L3), northwest side of melter

The condition of the glass contact refractory (Monofrax ${ }^{\circledR} \mathrm{K}-3$ ) at the melt line along the west side of melter is shown in Figure 5-33. The refractory appears to be undercut to some degree at the melt line. An estimate of the reduction in refractory thickness is difficult based solely on the visual inspection. Judging by the angular appearance of the refractory face, it appears that spalling has occurred. 


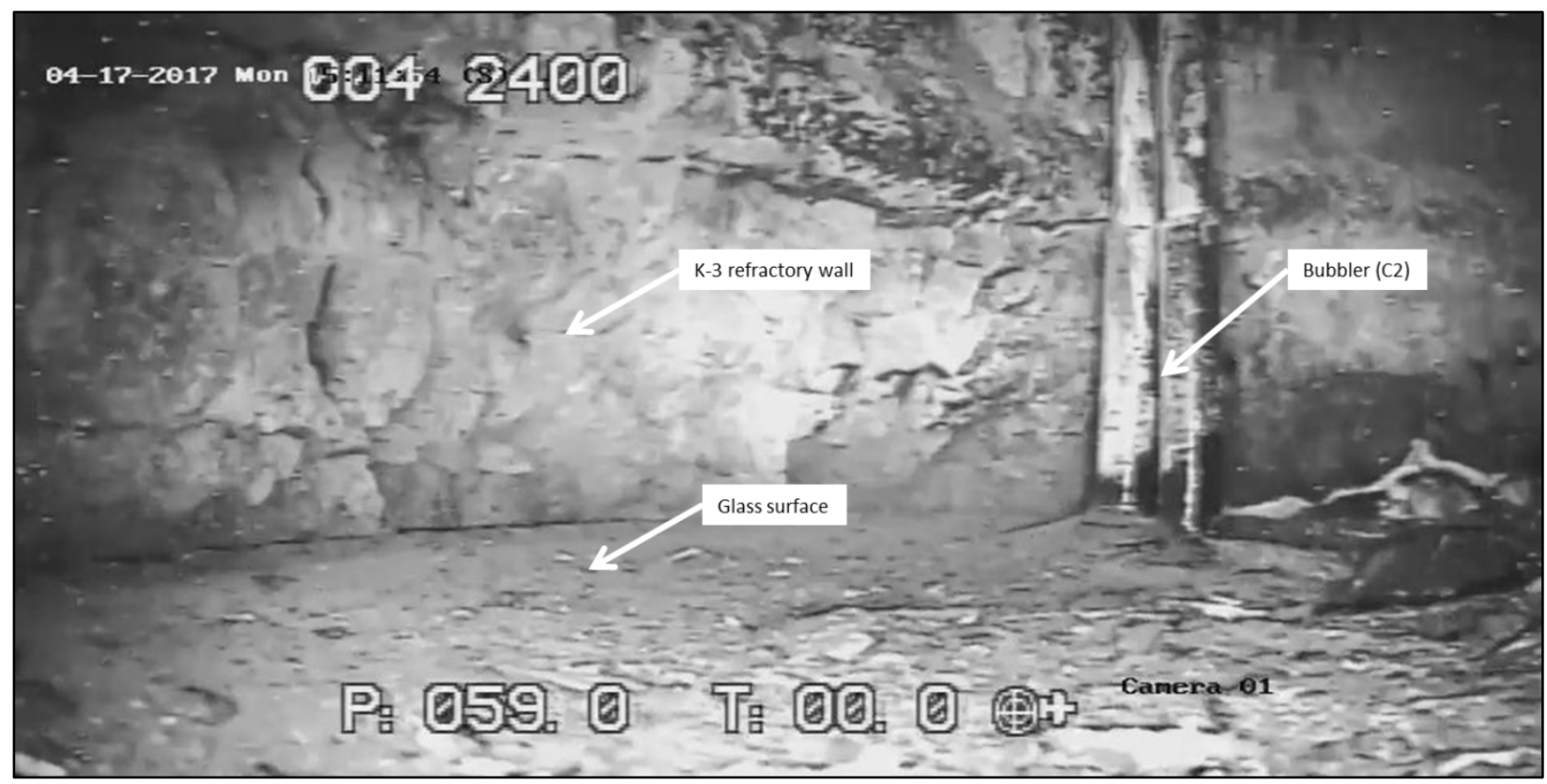

Figure 5-33. Glass contact refractory at melt line, west side of melter

Figure 5-34 is a view of the glass contact refractory at the melt line in another area along the west side of the melter. Some of the refractory again appears to have spalled away. The degree of refractory spalling appears to be worse than what was observed in the Melter 1 inspection, ${ }^{2}$ although the service life of Melter 2 was approximately double that of Melter 1. An accumulation of glass stringers (narrow filaments) is also visible.

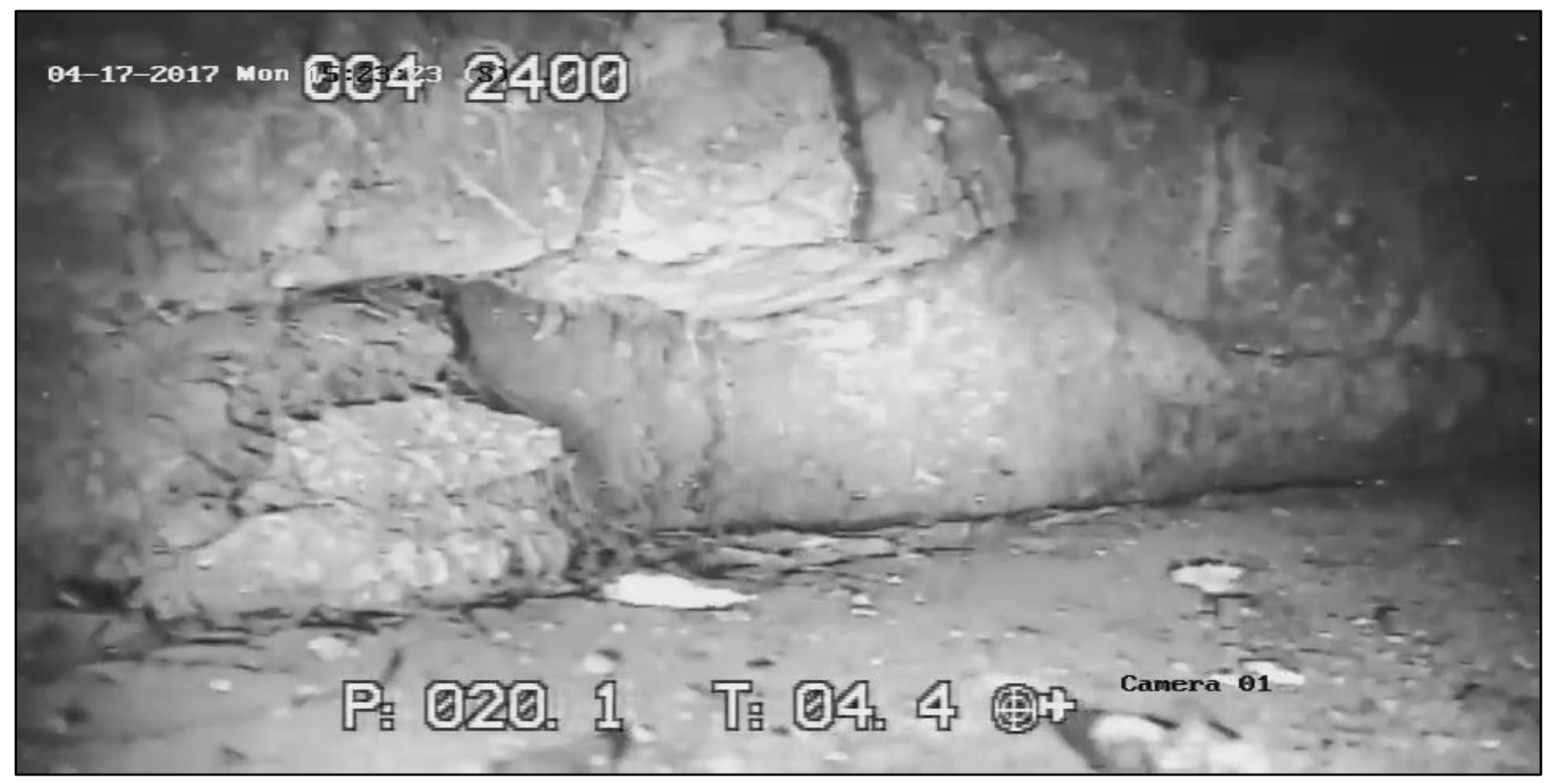

Figure 5-34. Second view of glass contact refractory at melt line, west side of melter 


\subsection{Glass Pool}

A mound of material at the center of the solidified melt pool was observed during the melter inspection, shown in Figure 5-35 and Figure 5-36. The cause of this mounding of material was not immediately apparent. The height of the mound was estimated to be twice the height of the exposed portion of the upper electrodes, about 6 inches.

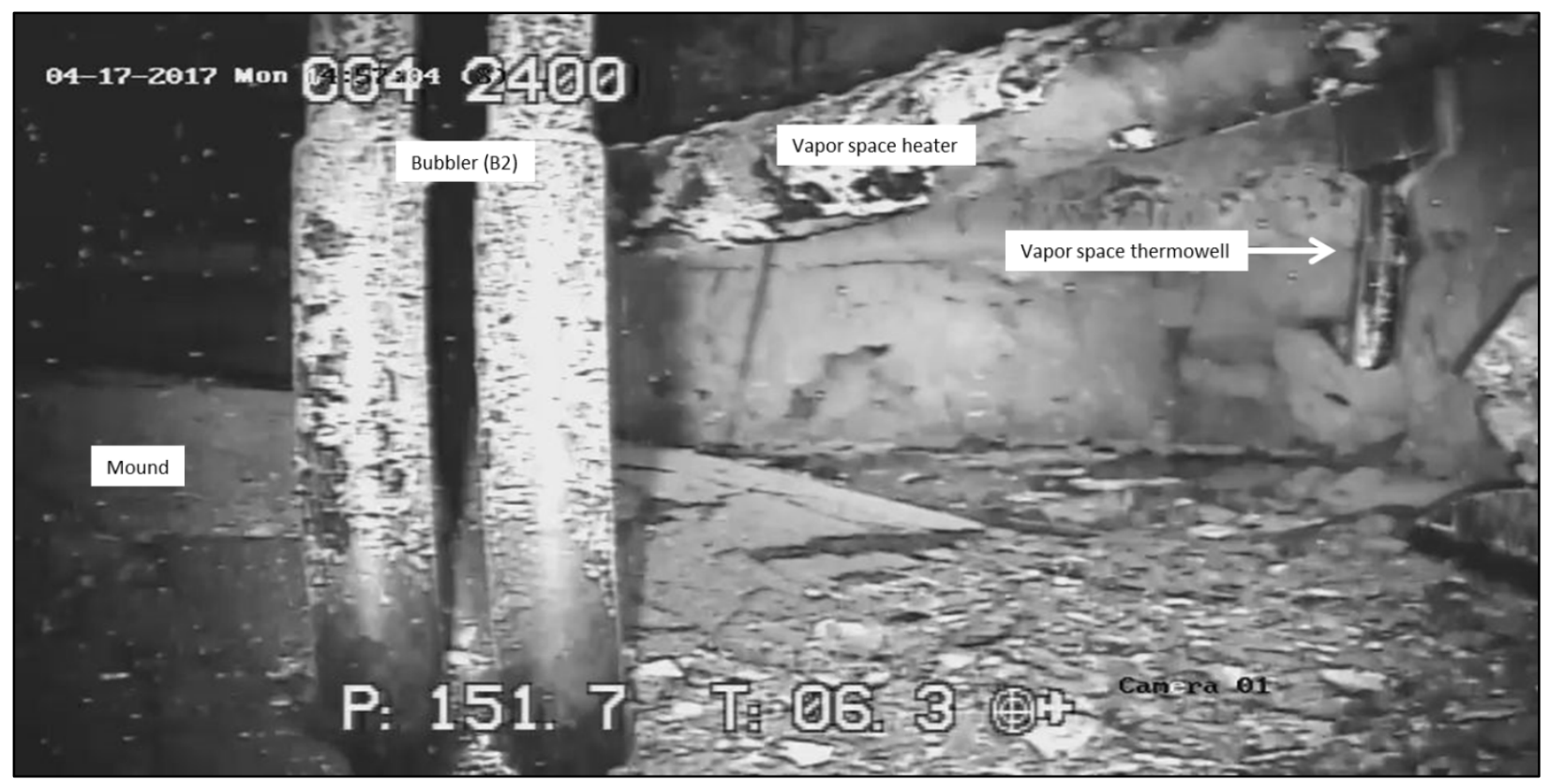

Figure 5-35. Southeast edge of mound of material visible on glass pool

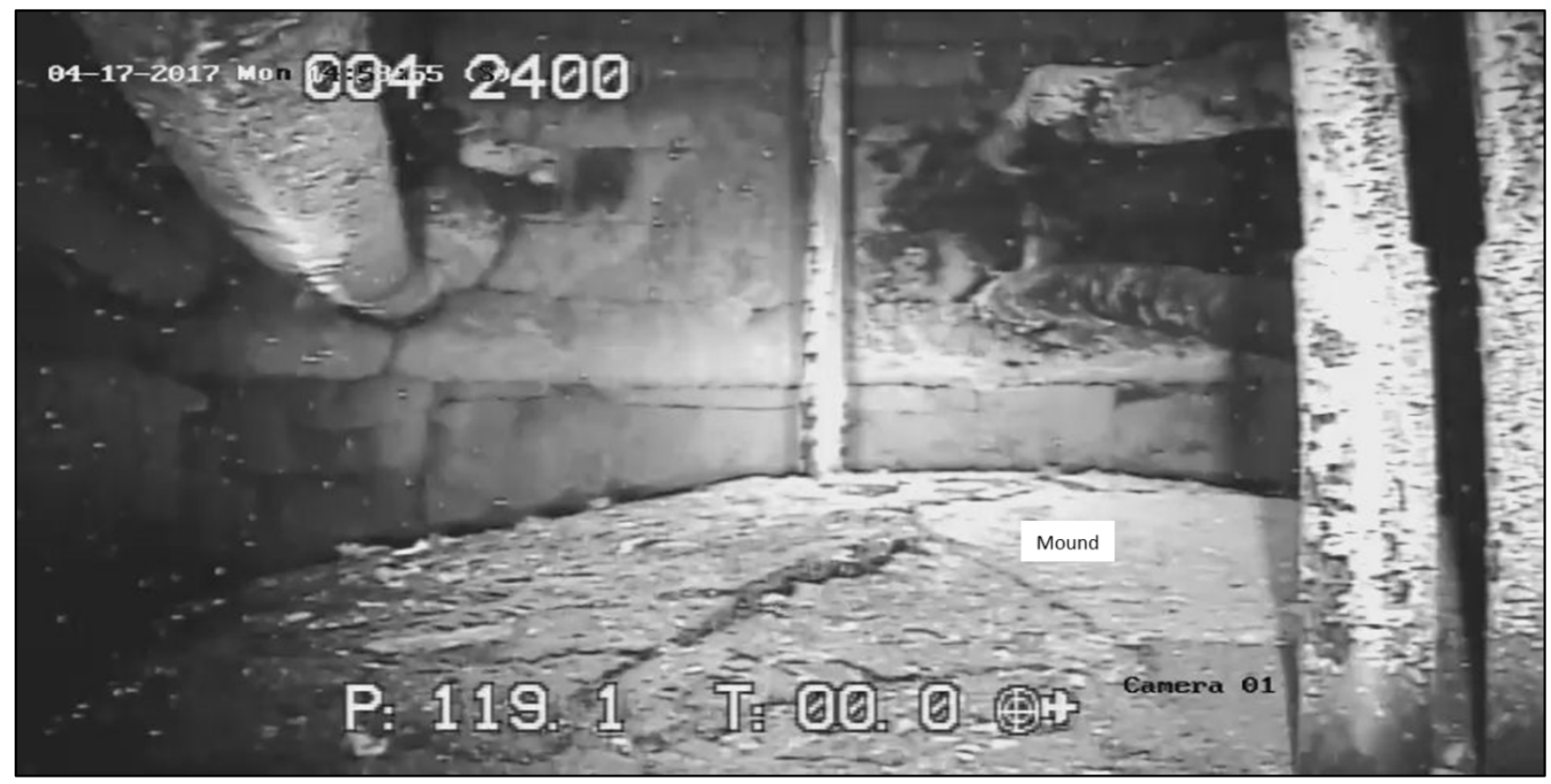

Figure 5-36. Mound of material at center of glass pool 
Upon closer inspection (Figure 5-37), it was postulated that the mound was composed of porous or "foamy" glass, a result of either the bubbling employed during cooling of the glass pool, the in-leakage of cooling water and subsequent steam generation at the L4 electrode stem, or both. It was also postulated that the mound could be unreacted feed material, although this was considered to be improbable due to the long idle period prior to melter shut down. Inspection of the fissures visible on the mound appeared to show either crystalline material or foamed glass. Observation was confounded by material that fell from the plenum refractory during cooling and settled on top of the solidified melt pool.

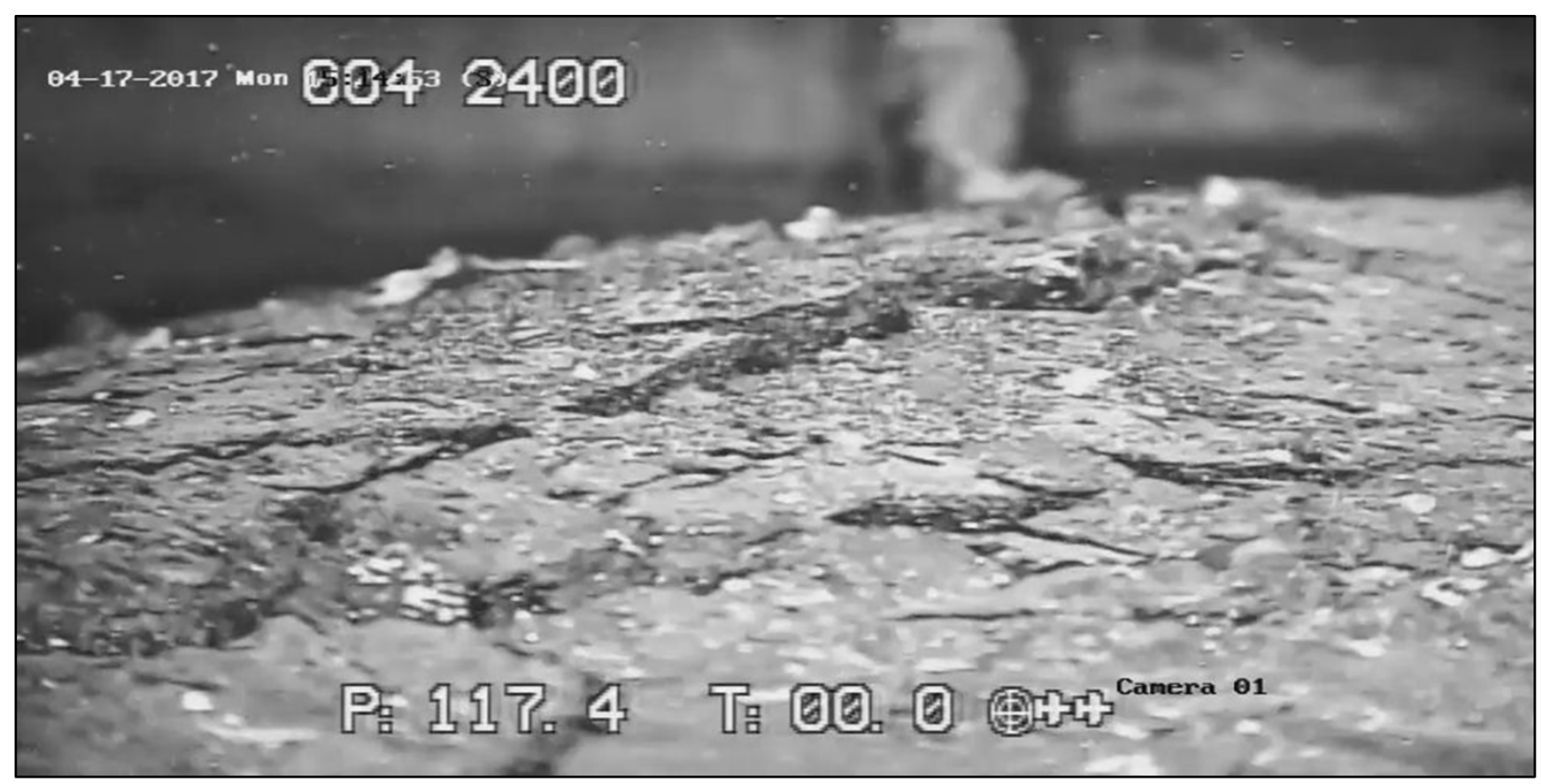

Figure 5-37. Fissures visible in mound of material

A previously used glass pump was retrieved with the crane and inserted through the center nozzle (Nozzle E) in an attempt to determine whether the mound was solid or whether it was the top of a large void (bubble), and to allow for further observations. Figure 5-38 and Figure 5-39 show the appearance of the mound after contacting it with the glass pump. 


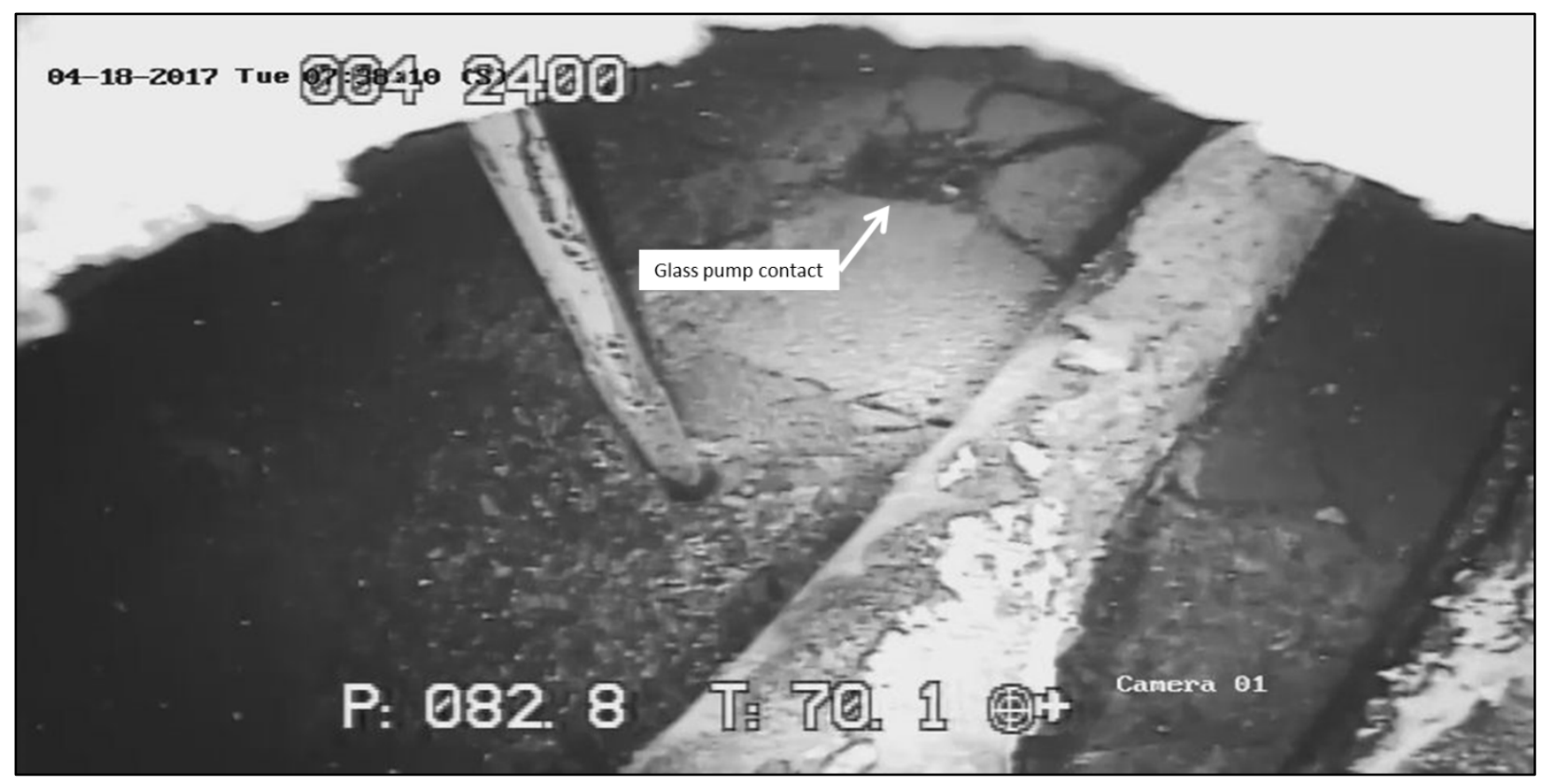

Figure 5-38. View of mound of material after contacting with glass pump through center nozzle

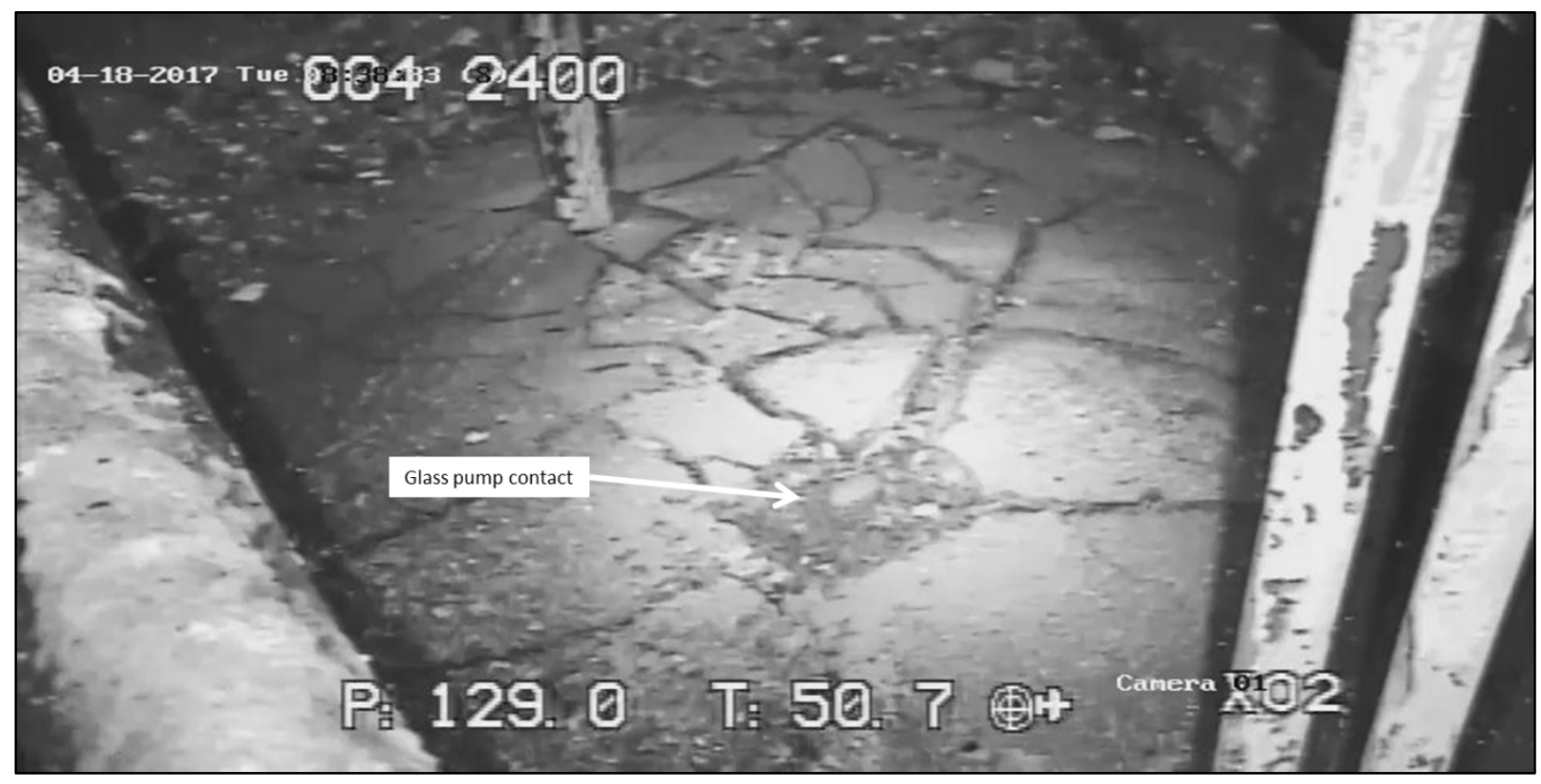

Figure 5-39. Alternate view of mound of material after contacting with glass pump

Figure 5-40 and Figure 5-41 are closer views of the area of the mound contacted by the glass pump. The surface of the mound appeared to have been broken into relatively large pieces. Inspection via the camera was determined to be insufficient for identifying whether the mound consisted of glassy or crystalline material. Therefore, a method for retrieving a sample of the mound material from the melter was developed and implemented, as described in Section 6.0. 


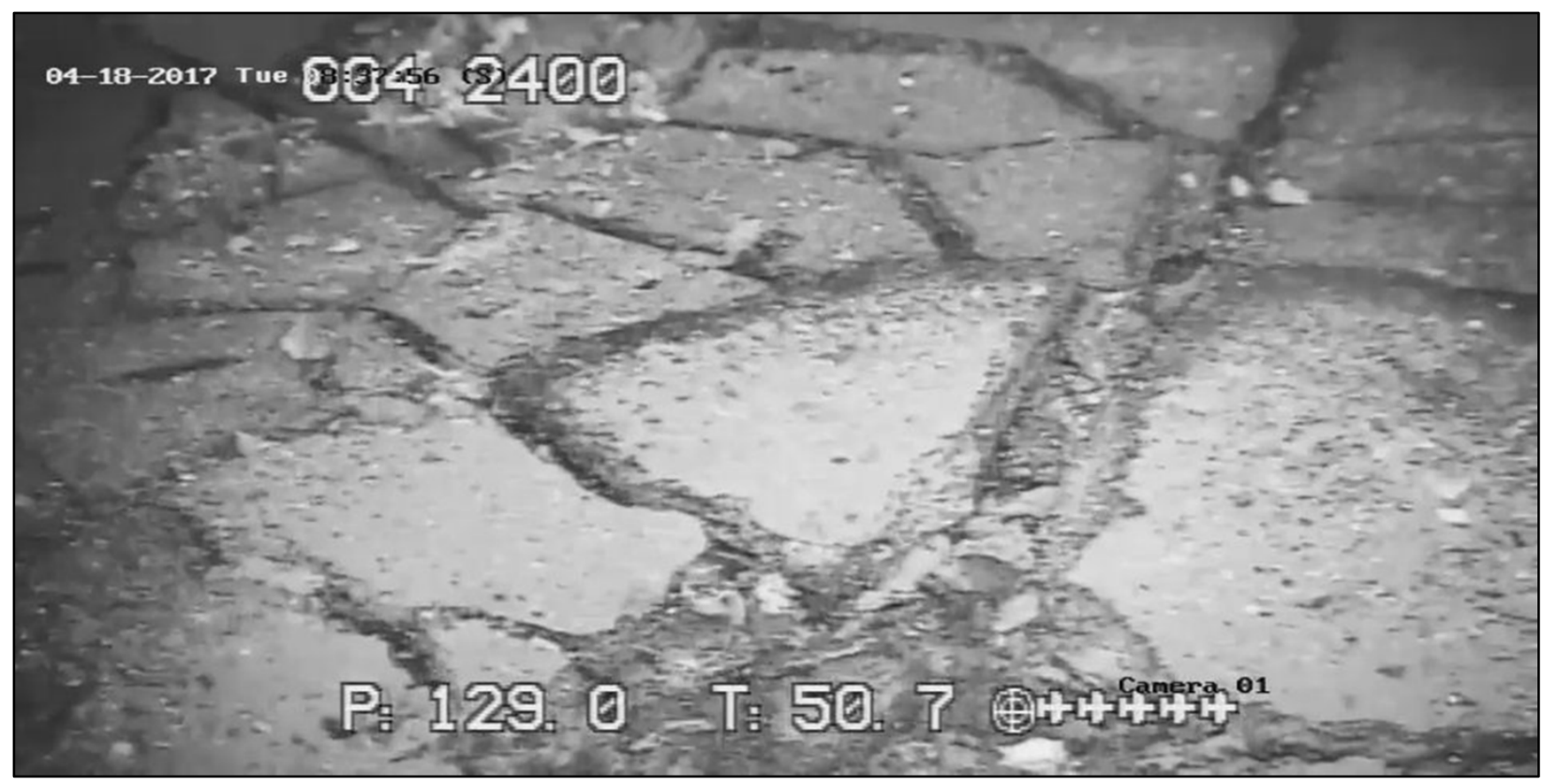

Figure 5-40. Cracked material atop mound after contacting with glass pump through center nozzle

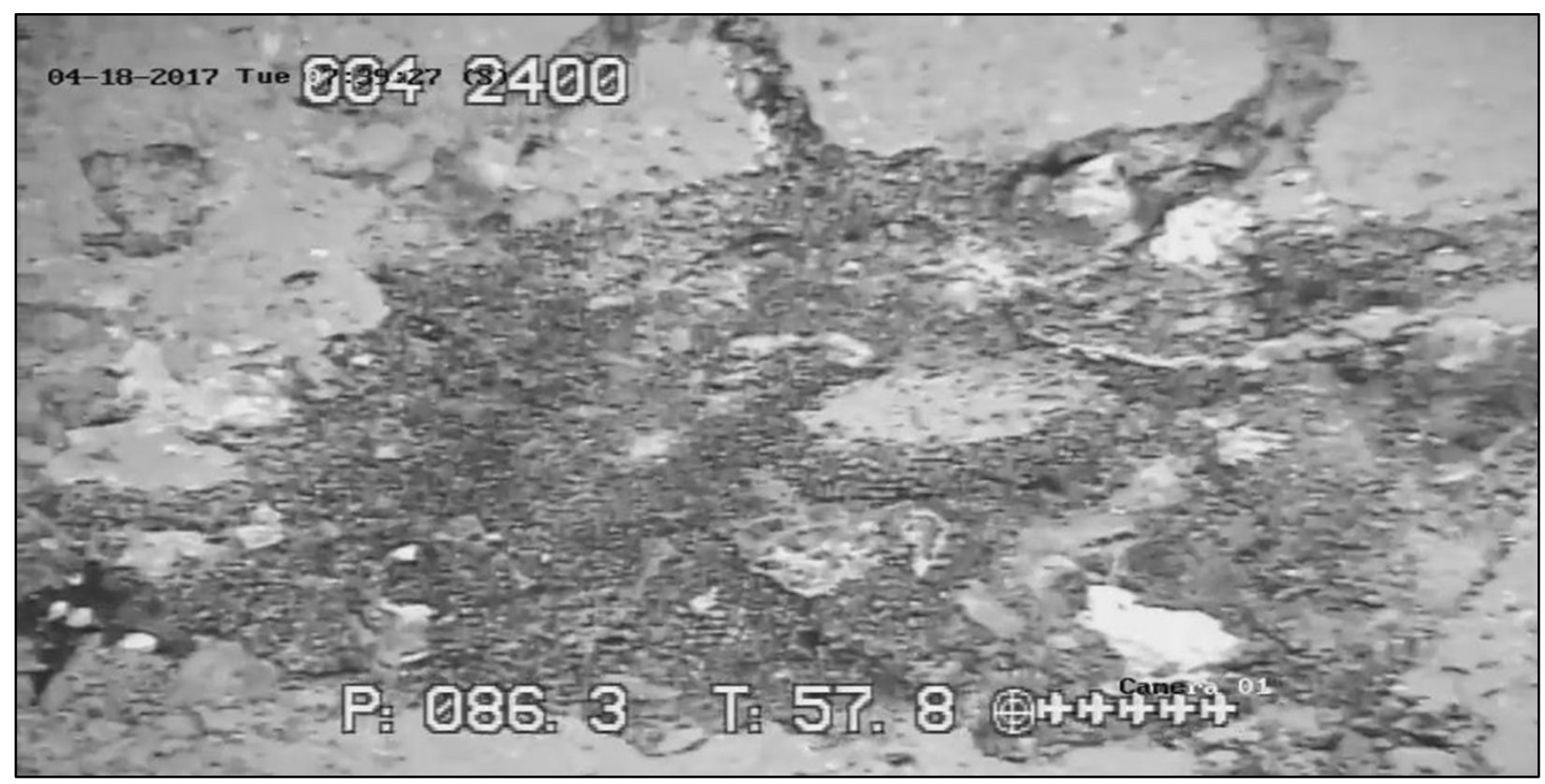

Figure 5-41. Closer view of cracked material atop mound

\subsection{Mound Sampling and Inspection}

Samples of the mound material from the melter were collected using discs mounted to a pole that was inserted through the center nozzle (Nozzle E) with the crane. The bottom surface of the discs were covered 
with a thick layer of duct seal compound. ${ }^{\text {a }}$ It was felt that the tackiness and compliance of this material would be successful in capturing material from the top of the mound.

Two samplers were inserted and removed from the melter. Both were successful in retrieving samples of the mound material. The retrieved samples were inspected visually through the melt cell window and using the camera mounted to the tele-robotic manipulator. The samples appeared to be a porous or "foamy" glass, as shown in Figure 6-1 and Figure 6-2. The glass was black and shiny. No crystalline material or unreacted feed was observed.

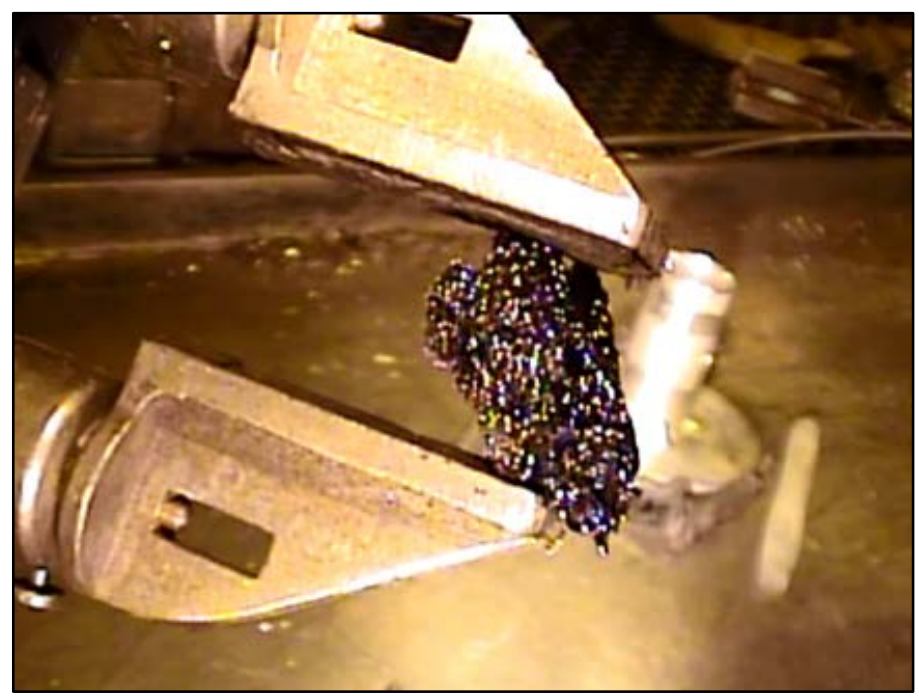

Figure 6-1. Foamy glass retrieved from mound in Melter 2

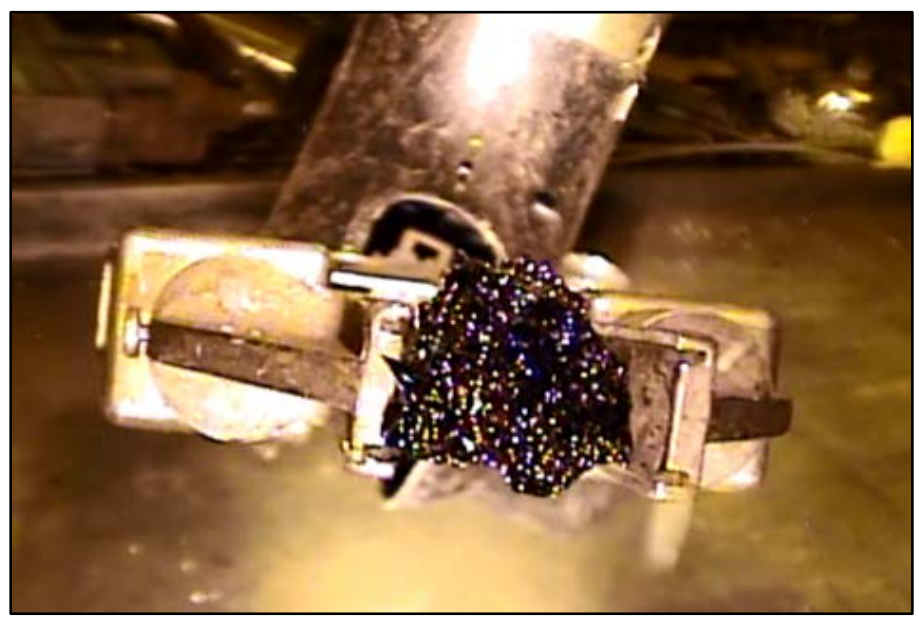

Figure 6-2. Alternate view of foamy glass retrieved from mound in Melter 2

Images of the first sampler are shown in Figure 6-3 and Figure 6-4. All of the material collected appeared to be black, shiny, porous glass. Similar foamy glass was generated in the past during stirred melter testing via rapid gas evolution in the glass pool, an example of which is shown in Figure 6-5.

\footnotetext{
${ }^{\text {a }}$ Gardner Bender, Part \# DS-130, Menomonee Falls, Wisconsin
} 


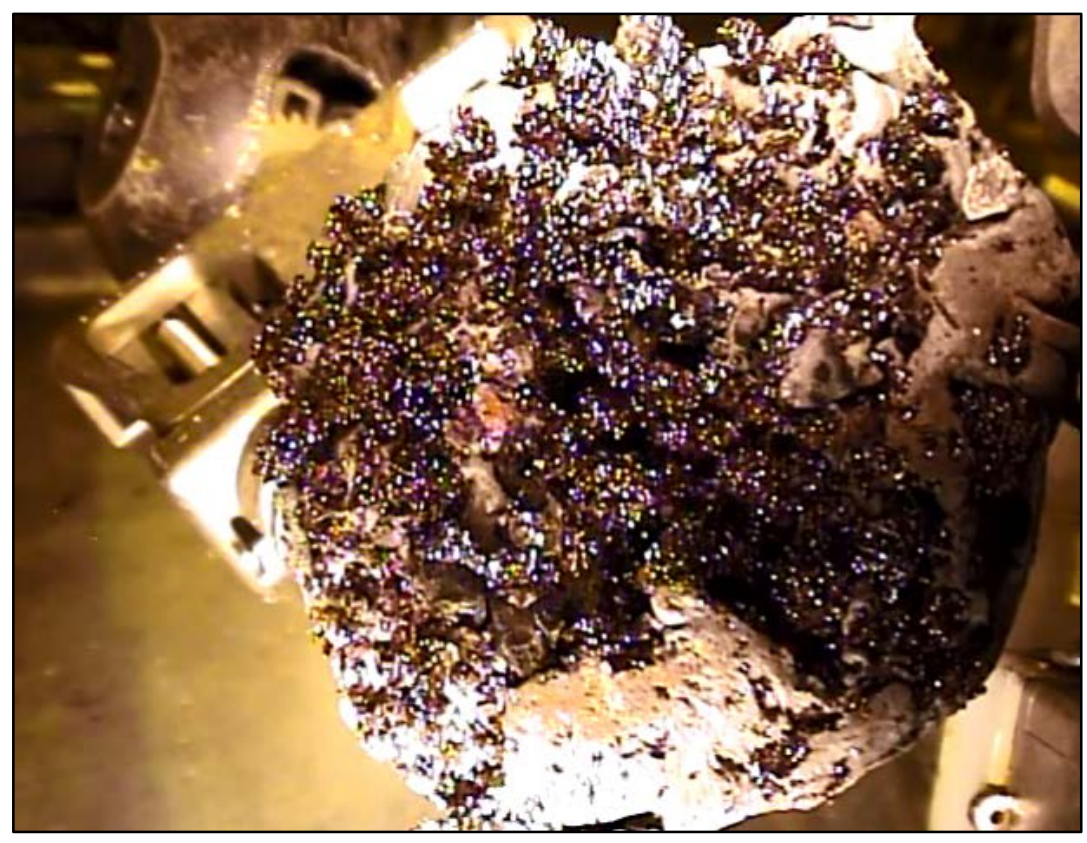

Figure 6-3. First sampler with glass collected from mound

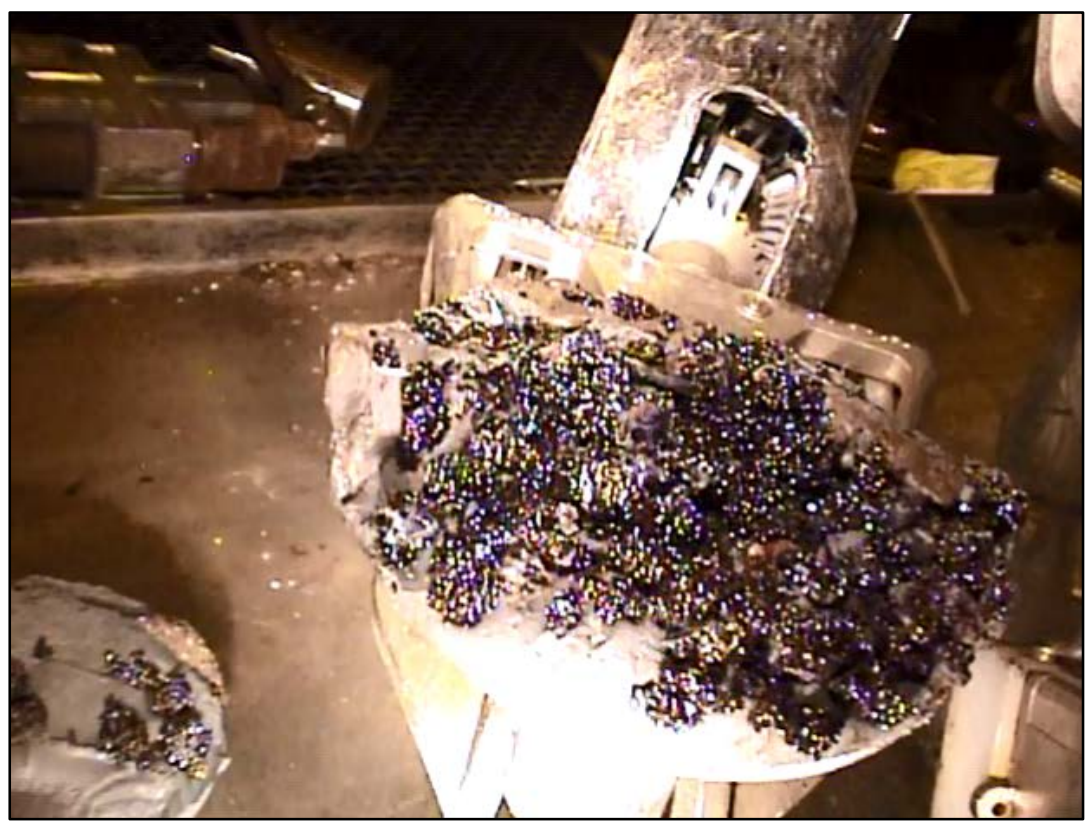

Figure 6-4. Alternate view of first sampler with glass collected from mound 


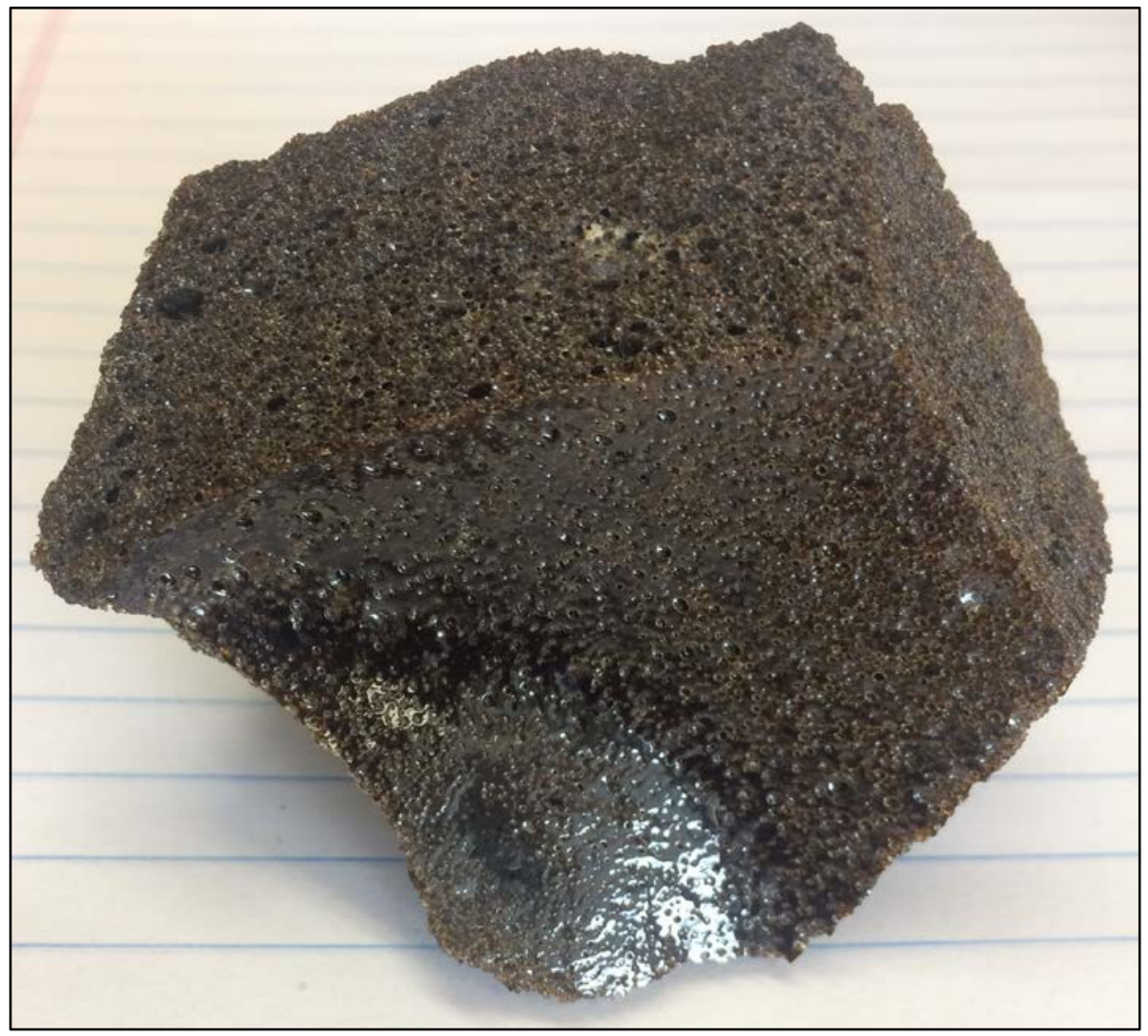

Figure 6-5. Example of foamy glass generated via rapid gas evolution in the glass pool during stirred melter testing

Images of the second sampler are shown in Figure 6-6 and Figure 6-7. Again, all of the material collected appeared to be black, shiny, porous glass. None of the material collected appeared to be crystalline or unreacted feed. Some of the collected material was placed into sample container PC0129 for further analyses, if needed at a later date. 


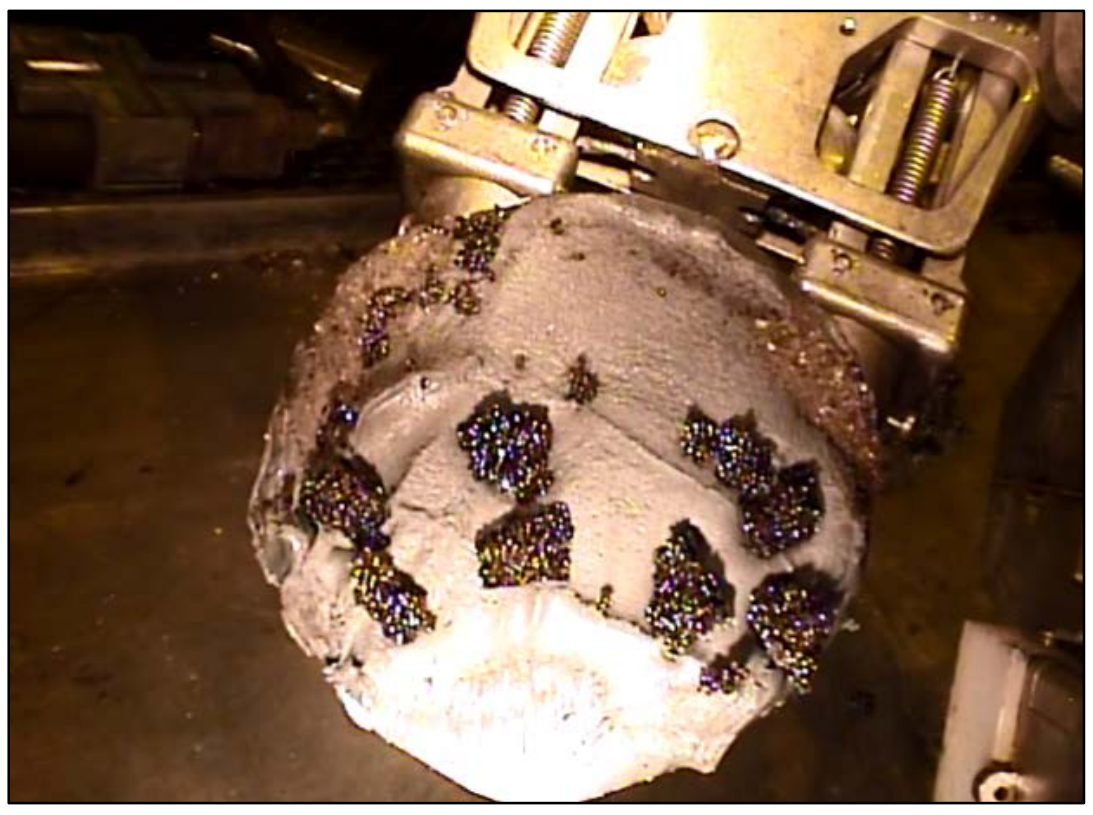

Figure 6-6. Second sampler with glass collected from mound

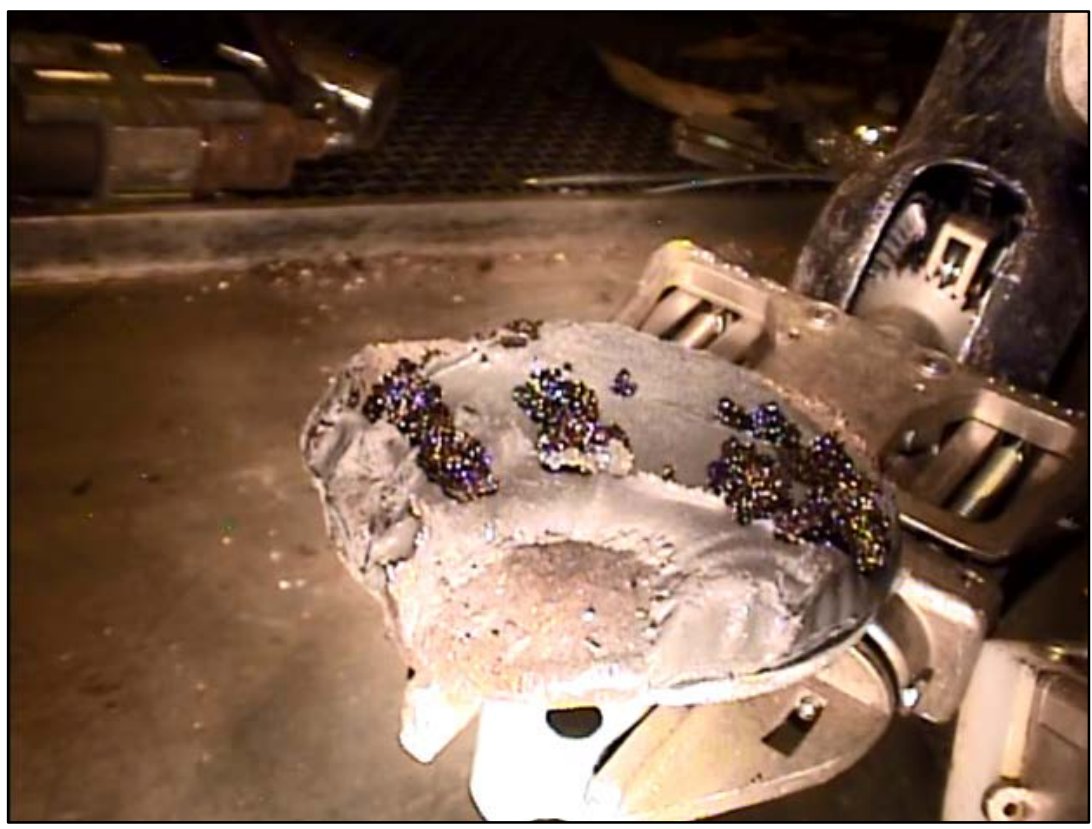

Figure 6-7. Alternate view of second sampler with glass collected from mound

\subsection{Pour Spout Inspection}

Visual evaluation of the condition of the riser and pour spout glass pour over point was not feasible due to poor imaging with the camera. For future inspections, the focal length of cameras used for this type of inspection will need to be reduced. The tele-robotic manipulator camera captured images of the lower portion of the pour spout, as shown in Figure 7-1. Portions of the removable insert, or glass disengagement point, were visible upon closer inspection (Figure 7-2). This region of the pour spout appeared to have remained in better condition compared to similar observations of Melter 1 . This may be because of the 
design and use of pour spout inserts, which were continuously used and periodically replaced throughout Melter 2 operation.

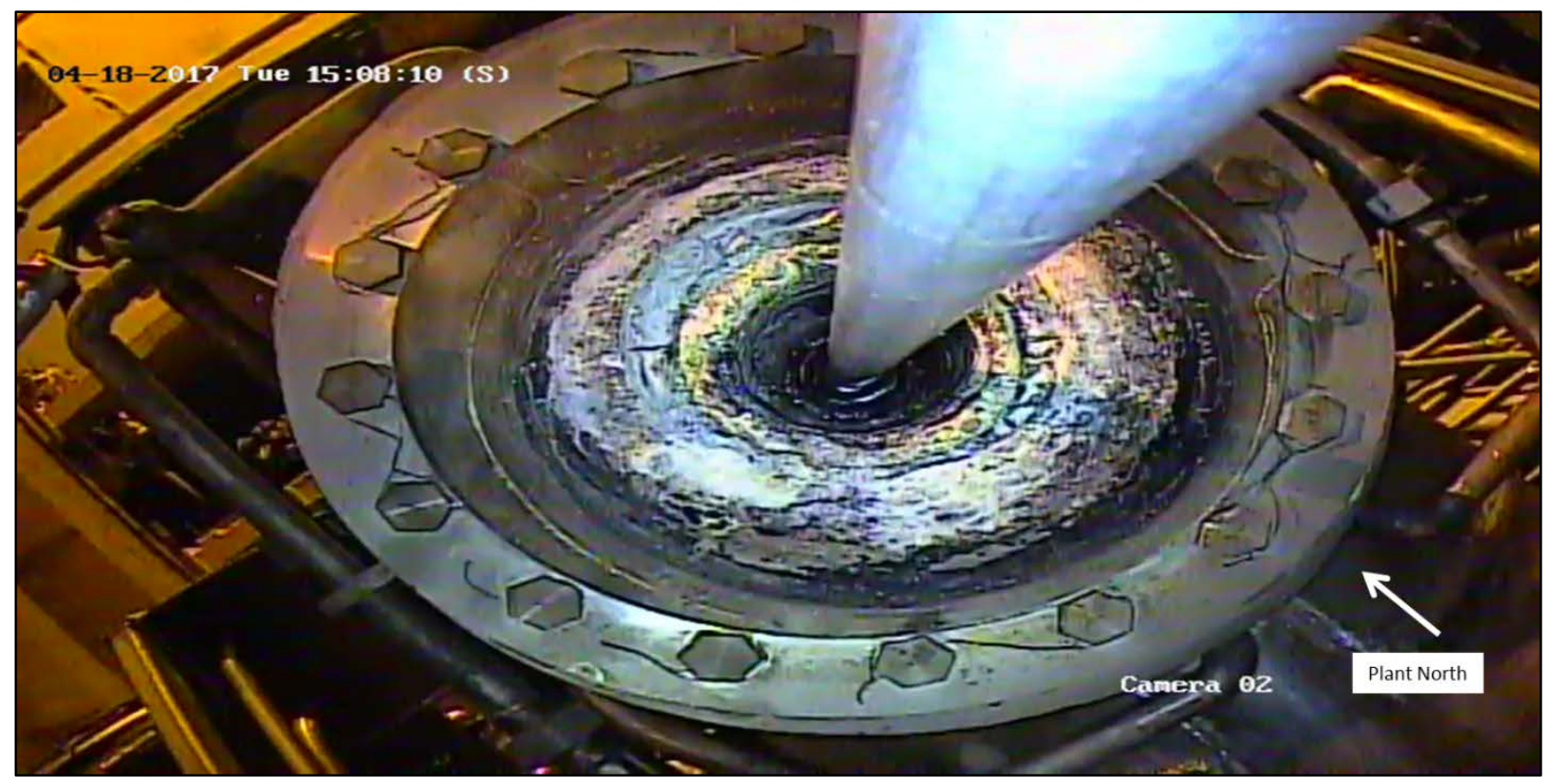

Figure 7-1. View of pour spout looking up toward top of melt cell with inspection camera system inserted

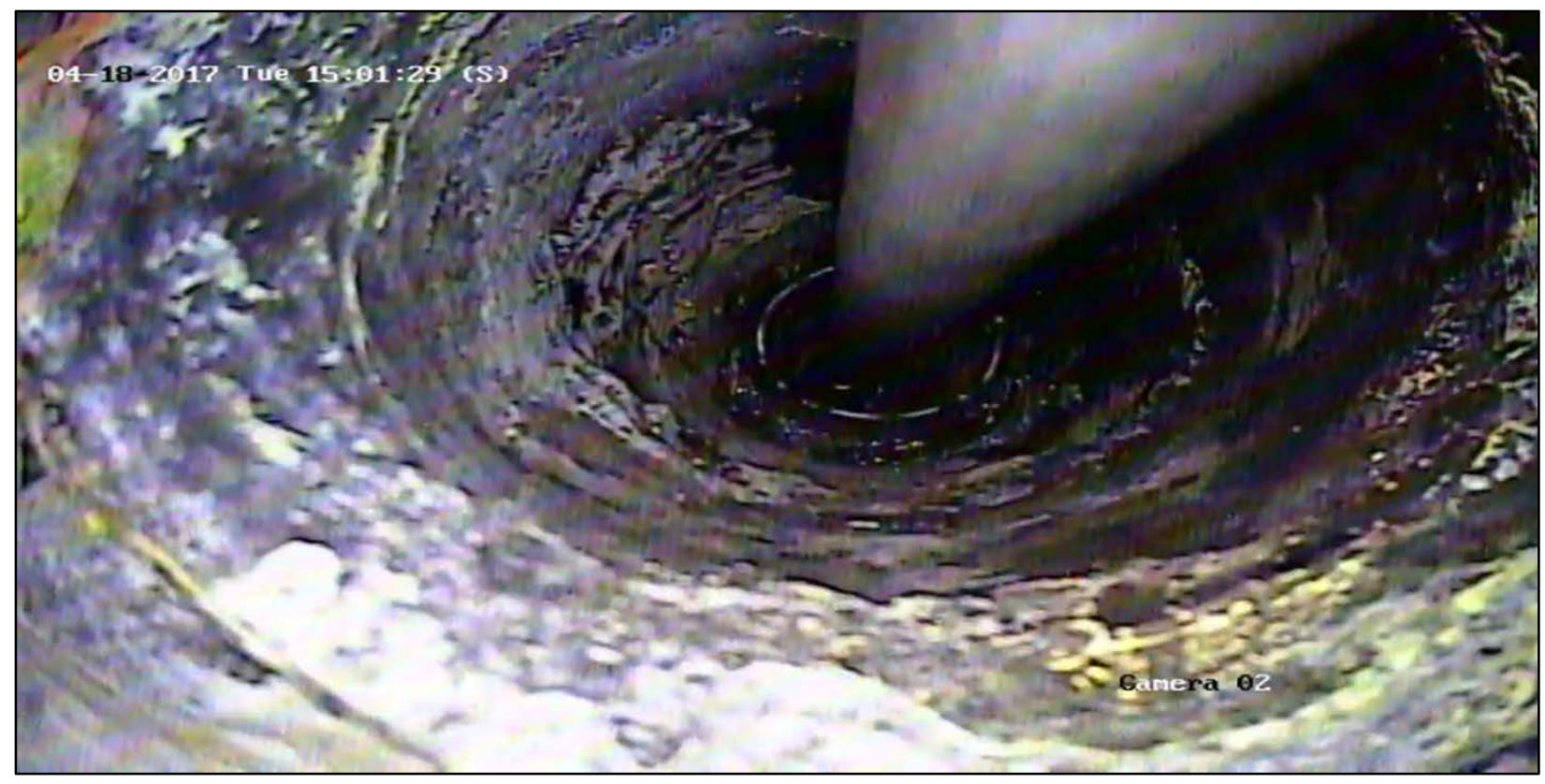

Figure 7-2. Closer view of pour spout showing region of removable insert with inspection camera system inserted 


\subsection{Summary}

DWPF Melter 2 reached its end of service life after nearly 14 years. Melter 2 produced approximately 10,868,000 pounds of vitrified HLW, filling 2819 canisters. A visual inspection of the interior of the melter was performed using a remotely operated camera to provide insight into melter performance and potential failure mechanisms. The condition of the interior of the melter was generally good considering its relatively long service life. The plenum refractory appeared to be in good condition. Spalling and wear of the glass contact refractory was evident at the melt line. The spalling was significant in the unretained K-3 ledge above each upper electrode. Spalling was less severe elsewhere around the melt line. It is not known whether the refractory degradation observed at the melt line continued in the melt pool. There appeared to be some degree of degradation and deposition of material at the dome heater penetrations. Deformation, or sagging of the dome heaters was visible. The visual inspection could not determine a mechanism for the failure of dome heater D.

Only the top surfaces of the upper electrodes were visible due to the full inventory of glass remaining after melter shutdown. The electrodes exhibited small cracks as well as minor deformation (creep or slumping). The lower electrode failure mechanism could not be determined since it was not visible. A potential failure mechanism is degradation of the Inconel 690 electrode via microstructural and chemical changes induced by long service in the molten glass environment.

An unexpected mound of material was visible near the center of the solidified melt pool. Samples of the mound material were retrieved for visual inspection, and observations concluded the samples to be black, shiny, porous glass. Based on the visual observations of the material collected from the mound, there was no reason to suspect issues with the quality of the glass product remaining in Melter 2. 


\subsection{References}

1. Iverson, D. C., “DWPF Glass Melter Technology Manual,” U.S. Department of Energy Report WSRCTR-93-587, Volumes 1-4, Westinghouse Savannah River Company, Aiken, SC (1993).

2. Iverson, D. C., K. J. Imrich, D. F. Bickford, J. T. Gee, C. F. Jenkins, and F. M. Heckendorn, “Examination of DWPF Melter Materials After 8 Years of Service," U.S. Department of Energy Report WSRC-MS-2003-00318, Washington Savannah River Company, Aiken, SC (2003).

3. Reed-Hill, R. E., Physical Metallurgy Principles, Second Edition, ISBN: 0-442-26868-8, (1973). 


\section{Distribution:}

J. W. Amoroso, 999-W

K. M. Brotherton, 704-27S

J. R. Cantrell, 704-S

A. S. Choi, 773-42A

M. Collins, 781-A

J. T. Coughlin, 730-A

A. D. Cozzi, 999-W

C. L. Crawford, 773-42A

P. E. Cundey, 704-30S

M. J. Dalmaso, 723-A

D. E. Dooley, 773-A

T. B. Edwards, 999-W

A. P. Fellinger, 773-42A

S. D. Fink, 773-A

M. D. Fowley, 786-A

K. M. Fox, 999-W

E. J. Freed, 704-S

T. L. Glover, 704-30S

J. C. Griffin, 773-A

E. K. Hansen, 999-W

C. C. Herman, 773-A

D. T. Herman, 735-11A

B. C. Hodges, 704-30S

J. F. Iaukea, 704-S

K. J. Imrich, 773-A

D. C. Iverson, 704-30S

C. M. Jantzen, 773-A

F. C. Johnson, 999-W
J. C. Kinney, 730-A

V. M. Kmiec, 704-27S

D. P. Lambert, 999-W

S. L. Marra, 773-A

C. J. Martino, 999-W

A. D. Marzolf, 723-A

G. J. Matis, 704-S

D. J. McCabe, 773-42A

D. L. McClane, 999-W

R. L. Minichan, 781-A

G. A. Morgan, 999-W

J. D. Newell, 999-W

Q. L. Nguyen, 704-30S

J. E. Owen, 704-30S

J. M. Pariezs, 773-A

F. M. Pennebaker, 773-A

A. A. Ramsey, 999-W

W. G. Ramsey, 999-W

A. V. Staub, 704-30S

M. E. Stone, 999-W

C. L. Trivelpiece, 999-W

Z. L. Wesley, 704-30S

B. J. Wiedenman, 773-42A

B. J. Wiersma, 773-A

M. S. Williams, 999-W

W. R. Wilmarth, 773-42A

J. R. Zamecnik, 999-W

Records Administration (EDWS) 